\title{
39. A SYNTHESIS OF NORWEGIAN SEA BIOSTRATIGRAPHIES: ODP LEG 104 ON THE VØRING PLATEAU ${ }^{1}$
}

\author{
Robert M. Goll ${ }^{2}$
}

\begin{abstract}
Summaries are presented of the 12 biostratigraphic contributions to this volume, which treat the calcareous, siliceous, and organic-walled microfossils preserved in the $1319.1 \mathrm{~m}$ of sediments and the thin shales intercalated in the 914.0-m-thick basalt series recovered on Leg 104. Biostratigraphic range data are synthesized into a lower Eocene to Pleistocene biostratigraphic framework for the sedimentary successions of the eight holes drilled at Sites 642, 643, and 644 on the Vøring Plateau. Upper Neogene successions 100.3 m thick at Site 643, 158.0-160.3 m thick at Site 642, and $252.8 \mathrm{~m}$ thick at Site 644 form a composite section that is regarded as $91 \%$ complete for the past $10.2 \mathrm{Ma}$. Aided by interpretable magnetic polarity records and discontinuous occurrences of calcareous microfossils, ages to the nearest 0.1 $\mathrm{Ma}$ are assigned to these sediments with reasonable confidence. Lower Neogene successions $117.7 \mathrm{~m}$ thick at Site 643 and $117.7 \mathrm{~m}$ thick at Site 642 form a composite section interpreted as $93 \%$ complete for the interval 13.4-23.5 Ma. Ages for these sediments are less confidently assigned as a result of the general absence of calcareous microfossils, more problematical polarity records and few tie points. Paleogene successions $155.2 \mathrm{~m}$ thick at Site 643 and $1107.1 \mathrm{~m}$ thick (including the basalt series) at Site 642 pose difficult correlation problems, and ages assigned to these sediments are a compromise between dinoflagellate biostratigraphy and the benthic foraminifer biostratigraphy by Kaminski (1988). Microfossil distributions discussed in the synthesis include: actiniscidians, Bolboforma, calcareous nannofossils, diatoms, ebridians, benthic and planktonic foraminifers, ostracodes, palynomorphs, radiolarians, and silicoflagellates.

Time intervals of 3.2 and 4.9 m.y. at Sites 642 and 643 , respectively, are represented by a major late-middle to earlylate Miocene hiatus. This and ten other hiatuses of lesser magnitude divide the Neogene sedimentary succession of the outer Vøring Plateau into ten sequences that are classified in a synthemic system. Leg 104 hiatuses are correlative with hiatuses recognized in the Pacific, and some appear to have equivalents in other regions of the Norwegian Margin and on the Jan Mayen Ridge. A biostratigraphic review of 14 Leg 38 sites indicates that the poorly understood Paleogene sedimentary successions of the Norwegian Sea may be represented by four major unconformity-bounded sequences of regional scope.
\end{abstract}

\section{INTRODUCTION}

Despite the combined total of $3038.2 \mathrm{~m}$ of sediments recovered on DSDP Leg 38 and ODP Leg 104 at 19 drilling sites in the Norwegian Sea (Fig. 1), the Cenozoic biostratigraphy of this region remains in a relatively early stage of development as compared to the levels of sophistication achieved for tropical and more temperate regions. Nevertheless, the results of Leg 104 represent a significant advancement in our efforts to elaborate an integrated biostratigraphic framework of this region, particularly with repect to the late Neogene (0-10.2 Ma). Additionally, important pelagic successions of early Neogene age previously unknown for the Norwegian Sea were recovered on Leg 104, and these sediments serve as the basis for less confidently formulated biozonations and age assignments. Although Leg 104 recovery also includes Paleogene mudstones, pyroclastics, and shale intercalations, our ability to agree on the chronostratigraphy of these sediments is woefully inadequate, but detailed studies of these sparse microfossil assemblages represent significant progress even for these problematical sequences.

Because of the many specialists who have conducted biostratigraphic investigations of Leg 104 sediments at disparate institutions without access to routine intercommunication and the abstruse problems inherent in these successions, a thorough review and synthesis of these results has become essential to propose tentative chronologies for the sedimentation history of each site. These difficulties have been compounded by the nu-

\footnotetext{
${ }^{1}$ Eldholm, O., Thiede, J., Taylor, E., et al., 1989. Proc. ODP, Sci. Results, 104: College Station, TX (Ocean Drilling Program).

${ }^{2}$ Continental Shelf Institute, Trondheim, Norway.
}

merous and extensive revisions in biostratigraphic interpretation that have occurred for many of the fossil groups since publication of the Leg 104 Initial Report. All biostratigraphers contributing to the present volume have conformed to the Cenozoic time scale of Berggren et al. (1985). Despite the geographic proximity of these three sites and the approximately coeval age of the oldest Neogene pelagic sediments at Sites 642 and 643, Leg 104 has presented many stimulating biostratigraphic problems, some of which have not been conclusively resolved. Consequently, it has been necessary to make controversial interpretations of the available data, which can be validated or rejected only by further investigations and possibly by additional future drilling on the Vøring Plateau or elsewhere in the Norwegian Sea.

The impetus to maximize Cenozoic biostratigraphic resolution for the Norwegian Sea is two-fold. Low-latitude biostratigraphy has benefited immeasurably as a result of studies of thick sedimentary successions with good magnetostratigraphic records from regions characterized by reasonably straightforward seafloor-spreading histories. Integration of biostratigraphy and magnetostratigraphy was an important objective of Leg 104, which met with partial success (see the Paleomagnetic Stratigraphy and Sedimentation Rates section). Because of the complex changes in the rates and directions of seafloor spreading that have taken place in the Norwegian Sea during the Cenozoic, it is apparent that biostratigraphy must play a larger role in the interpretation of its tectonic history, and greater resolution will be required as new studies are initiated. Secondly, as scientific and commercial exploration progresses in the Arctic Ocean, it is clear that high arctic chronostratigraphy must be founded on a thorough understanding of subarctic biostratigraphy, particularly that of the Norwegian Sea. 


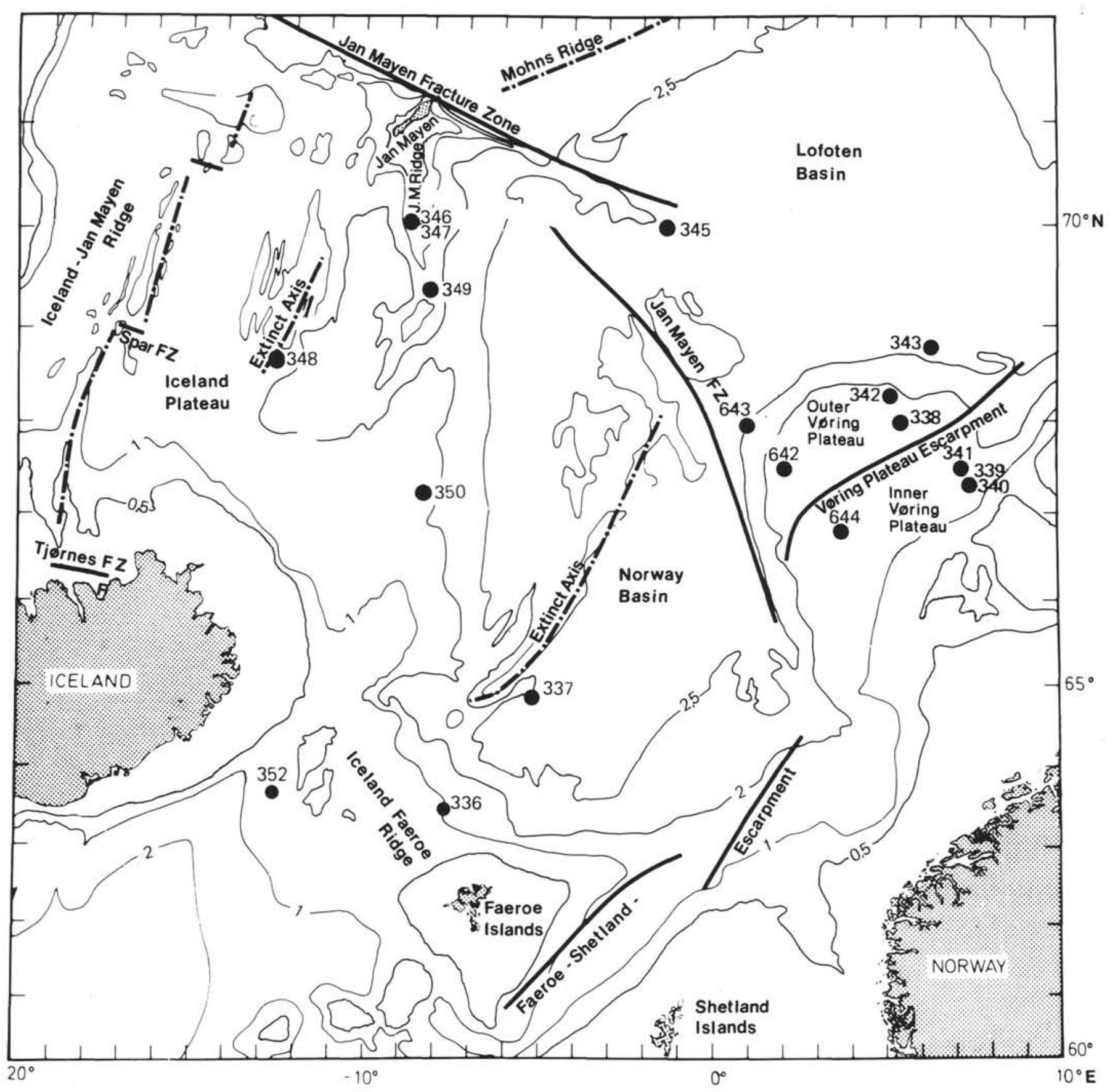

Figure 1. Locations of DSDP Leg 38 and ODP Leg 104 drilling sites. Sites 346 and 351 are not shown. Contours are in kilometers. (After Talwani and Eldholm, 1977.)

A total of 13 papers treating the broad range of fossils encountered in Leg 104 sediments are included in this volume. With the exception of the paper describing reworked foraminifers by Spiegler (this volume), all of these contributions are reviewed in this synthesis. Marine microfossils have received the greatest attention, although pollen and spores have been reported by Boulter and Manum (this volume), Manum et al. (this volume), and Mudie (this volume), all of whom additionally have investigated dinoflagellates. Calcareous microfossils treated in this volume include: Bolboforma, calcareous nannofossils, benthic and planktonic foraminifers, and ostracodes. Siliceous microfossils include: ebridians, actiniscidians, radiolarians, and silicoflagellates. Although extensively discussed in the Leg 104
Initial Reports by P. F. Ciesielski, diatoms are not formally treated in this volume, but range termination data on selected taxa are in Ciesielski and Case (this volume). All of the biostratigraphers present on the JOIDES Resolution during Leg 104 are represented by authorship of these papers. Additionally, 11 other specialists have contributed to these chapters, either as junior authors or as authors of separate chapters.

The lack of an established Cenozoic biostratigraphic system for the Norwegian Sea has been a source of frustration to many of the authors of this volume. Existing biozonations have been employed unchanged or in an emended form for some fossil groups, but other specialists have found it necessary or desirable to propose new biozonations based on Leg 104 sediments. The 
biostratigraphic information presented in the Initial Reports was based to a large degree on the examination of core-catcher sediments and a sparse subset of intermediate samples. For many contributors, this sample base proved to be inadequate, and the examination of many supplementary samples has demonstrated the need for extensive revisions of the biostratigraphies previously presented. Although Bolboforma, actiniscidians, and ebridians were not considered in the Initial Reports, biozonations based on these microfossils are included in the present volume.

Based on both Leg 38 and Leg 104 results, it is apparent that the Cenozoic history of the Norwegian Sea basin has been characterized by frequently interrupted sedimentation. In this respect, the Vøring Plateau is similar to the eastern margin of North America. Olsson and Melillo (1987) recognized four stacked Miocene sequences in the Calvert Formation of the subsurface of the Maryland coastal plain, which were correlated with thirdorder transgressive system tracts of the global cycle chart (Haq, Hardenbol, and Vail, 1987). The latter relationship is not demonstrable for Leg 104 sites, and alternative correlations will be proposed in this synthesis. A nomenclature scheme of synthems (in the sense of Salvador, 1987) is proposed to identify the Neogene hiatus-bounded sequences recognized in Leg 104 sediments. Although the nature and use of such units is controversial (Murphy and Salvador, 1988), they expedite site-to-site comparisons of Leg 104 sequences that are not distinguishable lithologically. These subsurface synthems qualify as mappable units only to the extent that the bounding unconformities are potentially traceable as seismic reflectors. Because they are recognized biostratigraphically, they have chronostratigraphic affinities and are interpretive to the extent that certain disagreement remains concerning Leg 104 hiatuses. The synthem-subsynthem hierarchy follows Owen (1987). Interthems in the sense of Chang (1975) are not employed.

Some of the Leg 104 unconformities are probably of regional magnitude, but others appear to be only local in scope. The thickest succession, for which we infer reasonably continuous sedimentation, accumulated over a time span of only approximately $3.4 \mathrm{~m}$.y. in the lower Miocene-middle Miocene succession in Hole 643A. Hiatus-bounded sediment packages representing time intervals inferred to be as short as approximately 0.2 m.y. (Core 104-642B-19H) also occur in these successions. Consequently, it has been necessary to correlate biostratigraphically short intervals, which can pose vexing problems even over short geographic distances and has been problematic between multiple holes at a single site (i.e., Site 642).

\section{GENERAL BIOSTRATIGRAPHY OF LEG 104 SITES}

Fossil assemblages variously composed of skeletal debris and palynomorphs have been found in Leg 104 sediments ranging from calcareous-siliceous ooze in the mudline cores to lower Eocene clay intercalations of the lower basalt series recovered in Cores 104-642E-102R to $-642 \mathrm{E}-104 \mathrm{R}$. The three sites occupied during Leg 104 are positioned on a northwest-to-southeast transect approximately $180 \mathrm{~km}$ long (Fig. 1), and similar sedimentary sequences were penetrated in the shallow recovery at each site. Glaciomarine intervals ranging in thickness from $51.3 \mathrm{~m}$ at Site 643 to $234.2 \mathrm{~m}$ at Site 644 are interpreted to have basal ages of $2.56 \mathrm{Ma}$ at each site. Low-diversity assemblages of calcareous microfossils and palynomorphs occur in these glaciomarine sediments, which are underlain by hemipelagic muds that are locally rich in calcareous nannofossils and contain lesser quantities of diverse siliceous and calcareous microfossils.

Coring at Site 644 terminated at a depth of 252.8 meters below sea floor (mbsf) in upper Pliocene sediments having an age judged to be $2.9 \mathrm{Ma}$. The succession penetrated at Site 644 on the inner Vøring Plateau differs from those of the outer plateau sites (642 and 643) in that sedimentation appears to have been essentially continuous during the onset of glaciation $(2.56 \mathrm{Ma})$, a biostratigraphic interpretation supported by the excellent geomagnetic polarity record (Bleil, this volume). Additionally, modest abundances of moderately to poorly preserved siliceous microfossils are sporadically present in glacial-interglacial sediments of the age range $0.75-2.56 \mathrm{Ma}$ (Locker and Martini, this volume; Goll and Bjørklund, this volume). Henrich (this volume) attributes these microfossil occurrences to the persistence of a weak flume of North Atlantic water over the inner plateau during the early Pleistocene. Both temperate and cold-water assemblages are present. The final decline in preservation of siliceous microfossils at Site 644 (top of lithologic Unit IC) is roughly coincident with the transition $(0.6-1.2 \mathrm{Ma})$ between an older climatic phase, characterized by zonal temperature gradients and weak glacials undergoing dominantly 41-k.y. cyclicity, and a younger climatic phase, characterized by meridianal temperature gradients and severe glacials undergoing dominantly 100 - to 400-k.y. cyclicities (Henrich, this volume).

Palynomorphs are generally present throughout much of the pre-glacial successions at Sites 642 and 643, but calcareous and siliceous microfossils have more variable distributions. The siliceous biogenic component becomes increasingly dominant with increasing depth, and calcareous microfossils and nannofossils are very rare or absent below $100.3 \mathrm{mbsf}$ at Site 643 and below $164.7 \mathrm{mbsf}$ at Site 642 . The oldest sediments in which calcareous assemblages occur with reasonable consistency have an age judged to be $13.6 \mathrm{Ma}$ at both Sites 642 and 643 . Middle to lower Miocene siliceous muds and oozes range down to $277.5 \mathrm{mbsf}$ at Site 642 and 273.8 mbsf at Site 643, with basal ages judged to be 21.7 Ma and 19.0 Ma, respectively. Both calcareous and siliceous microfossils are extremely rare and generally totally absent in the underlying sections at each site, with a few exceptions that will be treated individually in the following discussion. Impressions and imprints of diatoms have been observed by SEM examination of the underlying muds at both sites (Henrich, this volume), but palynomorphs and agglutinated foraminifers provide the only reliable biostratigraphic control.

Abrupt changes in lithology characterize the basal pelagic sequence contacts at both Sites 642 and 643 , but the age relations of these contacts are as yet uncertain and in part controversial. Below the siliceous mud section at Site $642,38 \mathrm{~m}$ of glauconyrich volcaniclastic and altered volcaniclastic muds and sands were recovered in the bottom of Hole $642 \mathrm{D}$, which overlie a pebble bed at the top of the 914-m-thick sequence of volcanic rocks and dikes penetrated in Hole 642E (the basalt series). The volcaniclastic unit was described as Eocene in the Initial Report, with an unconformable relationship to the overlying Miocene muddy oozes. Isotope geochemical age determinations based on these glauconies support an Eocene age for this unit (Smalley, Qvale and Qvale, this volume), but subsequent more thorough biostratigraphic analyses have led to markedly different interpretations. Abundant early Miocene dinocyst assemblages lacking admixed older taxa have been found in the upper $21 \mathrm{~m}$ of this volcaniclastic unit (Manum et al., this volume). Locker and Martini (this volume) and Ciesielski and Case (this volume) also report the presence of sparse fragmentary silicoflagellates in the same interval, but these microfossils are regarded as reworked. Manum et al. (this volume) regard the upper $21 \mathrm{~m}$ of the volcaniclastic unit as no older than basal Miocene. Their interpretation implies the existence of a major unconformity within the volcaniclastic unit at a depth of $299.2 \mathrm{mbsf}$, with the underlying volcaniclastic sediments and pebble bed having an age of early Eocene on palynological evidence. The only biostratigraphic data reported in this volume for the basalts recovered in Hole 642E are those of Boulter and Manum, who identified early Eocene or questionably Paleocene palynomorphs in the volcaniclastic mudstone intercalations near the base of the lower basalt series. 
This controversy is further discussed in the Paleogene Biostratigraphy section.

There is a sharp contact in Hole 643A between the siliceous ooze succession and the underlying $164.5 \mathrm{~m}$ of compactionlaminated mudstones and zeolitic claystones resting on basement basalt. As at Site 642 , the age relations of this sharp lithologic contact are not well established. These mudstones were described in Eldholm, Thiede, Taylor, et al. (1987b) as containing sporadic minor biogenic opal, but the only siliceous microfossils reported for this interval are rare radiolarians in Cores 104643A-30X to $-643 \mathrm{~A}-32 \mathrm{X}$ (Goll and Bjørklund, this volume). Only the radiolarian assemblage in Core 104-643A-30X is age diagnostic (late early Miocene), although these microfossils may represent down-hole contamination. Consequently, age indications for much of this sequence have been derived only from dinoflagellate and sparse agglutinated foraminifer assemblages that have been variously interpreted. Calcareous nannofossils indicate that the Oligocene/Miocene boundary occurs in a $0.5 \mathrm{~m}$ thick chalk bed at 400.4 mbsf (Donnally, this volume), an interpretation supported by the observation of Miocene dinoflagellates $10 \mathrm{~m}$ above this horizon. Dinoflagellate biostratigraphy indicates that the underlying section is of Oligocene age to an approximate depth of $478 \mathrm{mbsf}$ and is unconformably underlain by $83 \mathrm{~m}$ of middle Eocene to questionably lower Eocene mudstones in basal contact with basalt. These dinoflagellate age interpretations are in partial disagreement with ages based on agglutinated foraminifers by Kaminski (1988) (see discussion in the Paleogene Biostratigraphy section).

Seismic reflection profiles crossing Site 643 suggest that the lower Miocene-middle Miocene section is deformed (Skogseid and Eldholm, this volume), and the upper surface of the compaction-laminated mudstones at 273.8 mbsf may have served as a glide plane for repeated mass movements over an extended interval of time with sediment transported down slope from higher elevations on the plateau. The sediments in Sections 104-643A$12 \mathrm{H}-1$ to $-643 \mathrm{~A}-12 \mathrm{H}-2$ were described as slump and debris flow deposits in Eldholm, Thiede, Taylor et al. (1987b), and these sediments have been difficult to interpret biostratigraphically. The underlying succession was described as bioturbated but otherwise undeformed, and horizontal bedding is detectable in many of these siliceous ooze cores. There are no obvious repetitions in the biostratigraphy or indications of admixture of fossil assemblages in this interval, but syndepositional slumping may have augmented autochthonous pelagic deposition at Site 643, which represents a potential source of problems for detailed correlations to sites from shallower depths (i.e., Site 642).

\section{MICROFOSSIL STUDIES BY GROUP}

\section{Bolboforma}

Abundant but sporadic occurrences of five Bolboforma species in middle and upper Miocene sediments at Site 642 were discussed briefly in Eldholm, Thiede, Taylor, et al. (1987b, pp. 129-130). The gross distribution of Bolboforma in the benthic foraminifer samples reported for Site 642 were listed in Table 14 of the site report, but no attempt was made to use these microfossils biostratigraphically. Qvale and Spiegler (this volume) document the distribution of 15 Bolboforma species in middle Miocene to lower Pliocene sediments at Sites 642 and 643 (Figs. 2-5), and a single occurrence (possibly reworked) of $B$. costairregularis is recorded in Pleistocene sediments in Hole 644A. These taxa form the basis for the recognition of seven total- or partialrange zones, which have been very useful for correlation between the interval in Hole $643 \mathrm{~A}$, where the polarity reversal record can be confidently assigned to Chrons C3B-C4A, and part of the succession at Site 642 characterized by pervasively positive polarity overprinting.
Bolboforma has its oldest occurrence in Leg 104 sediments at the base of the calcareous sequence (interpreted age, 13.6 Ma), and they are locally abundant and continuously present in Site 642 sediments ranging in age from ca. 8 to $10.2 \mathrm{Ma}(B$. reticulata to $B$. fragori Zones). Only very limited occurrences of the three youngest zones (B. metzmacheri, B. intermedia, and B. costairregularis) are recorded in Holes 642B and 642C, and these zones are separated by barren intervals 6 to $22 \mathrm{~m}$ thick. $\mathrm{Bol}$ boforma are essentially absent in sediments judged to be younger than ca. $4 \mathrm{Ma}$, although moderately abundant assemblages of other calcareous microfossils occur sporadically in younger sediments at this site.

A complete succession of all seven zones has not been observed at any single Leg 104 site. Bolboforma are reported in a 30 -m-thick interval in Hole 643A ranging in age from 7.0 to 8.8 $\mathrm{Ma}$. Sediments coeval with the oldest zone and the two youngest zones recorded at Site 642 are missing at Site 643 . The B. laevis Zone is recognized in Hole $643 \mathrm{~A}$, but this zone is absent in Holes $642 \mathrm{~B}$ and $642 \mathrm{C}$, and coeval sediments may lie within the barren intervals between the $B$. fragori and $B$. metzmacheri Zones in these holes.

The B. costairregularis Zone is recorded in Site 642 sediments judged to have ages of 4.3-4.4 Ma, and it is also recorded in a single sample with an approximate age of $1.2 \mathrm{Ma}$ in Hole $644 \mathrm{~A}$, although the latter occurrence is regarded as contamination. In general, however, Bolboforma taxa present in Leg 104 sediments have earlier last occurrences than have been reported for the same taxa at localities south of the Greenland-Scotland Ridge, which may be a further expression of the deteriorating Pliocene climates in the Norwegian Sea inferred by Donnally (this volume). These observations provide a cautionary note for correlations over long latitudinal distances or between regions characterized by different surface water masses with the Pliocene of the Norwegian Sea, and perhaps for a greater interval of time as well.

\section{Calcareous Nannofossils}

Because paleoenvironmental conditions on the Vøring Plateau for long intervals of Cenozoic time were unfavorable or only marginal for the production of coccolithophorids as well as the preservation of their skeletal debris, calcareous nannofossil assemblages in Leg 104 sediments are characterized by sporadic occurrences, low diversity and generally poor preservation. Consequently, the biozonation (six zones) employed by Donnally (this volume) has undergone comparatively little revision from that presented in Eldholm, Thiede, Taylor, et al. (1987b), and the stratigraphic positions of zonal boundaries are readjusted slightly. Holes $642 \mathrm{~B}, 643 \mathrm{~A}$, and $644 \mathrm{~A}$ are treated in detail by Donnally, but only zone boundaries are given for Hole $642 \mathrm{C}$, and all Hole 642D sediments are reported to be barren. New information in this contribution includes a more detailed description of the distribution of calcareous nannofossil-bearing sediments, and a thorough discussion of the probable origins of reworked specimens that commonly dominate the glacial sediments.

A high percentage of the 1500 samples examined for calcareous nannofossils are barren. With the exception of a $0.5-\mathrm{m}$ thick chalk bed of latest Oligocene (? basal Miocene) age in Hole $643 \mathrm{~A}$, calcareous nannofossils are essentially absent in Leg 104 sediments older than $13.6 \mathrm{Ma}$, and occurrences are sporadic in younger sediments at Sites 642 and 643 . The quality of preservation is described as moderate to poor, except for a $20-\mathrm{m}$ Pliocene interval in Hole 642B (judged to be 3.1-4.8 Ma), where abundant, well-preserved specimens are recorded. In these highlatitude floras, discoasters, ceratoliths, and sphenoliths are extremely rare or absent, and only 27 species are identified. The last occurrences of Discolithina enormis, Cyclicargolithus flori- 
danus, Reticulofenestra pseudoumbilica, and Pseudoemiliania lacunosa, and the first occurrence of Emiliamia huxleyi define the tops of zones NP25, NN6, NN15, NN19, and NN20 of Martini (1971), respectively. This scheme is similar to that employed for DSDP Leg 38 by Müller (1976), who additionally recognized zones NN3-NN4 at Site 338 on the basis of the occurrence of Helicosphaera ampliaperta. This latter species is not observed in Leg 104 sediments. According to Figure 9, however, only sediments coeval with the lower half of the $H$. ampliaperta Zone occur at Site 642, and coeval noncalcareous sediments in Hole 643A (180-220 mbsf) presumably accumulated at water depths approximately twice as great as those at Sites 338 and 642.

Sediments below 162 mbsf in Hole 642B are essentially barren of calcareous nannofossils, and the occurrences above this horizon are distributed in four sequences separated by barren intervals $12-28 \mathrm{~m}$ thick. The last occurrence of $C$. floridanus at $156 \mathrm{mbsf}$ indicates an age of approximately $13.4 \mathrm{Ma}$ for this horizon, but an alternative explanation will be proposed in the $\mathrm{Ne}$ ogene Biostratigraphy section. In Hole $642 \mathrm{C}, C$. floridanus is not recorded above the major middle Miocene hiatus, and the Zone NN6/NN7 boundary (158 mbsf) is $3.7 \mathrm{~m}$.y. older than in Hole 642B. This descrepancy probably results from the coarser sampling of Hole $642 \mathrm{C}$ in this highly condensed portion of the succession. The last occurrence of B. pseudoumbilica is recorded at $78 \mathrm{mbsf}$, and the immediately overlying sediments contain $P$. lacunosa. The association of these two events should be a reliable indication of the Zone NN15/NN16 boundary, which has been assigned an age of $3.4 \mathrm{Ma}$ by Berggren et al. (1985). However, the polarity reversal record for this interval of Hole $642 \mathrm{~B}$ has been referred to Chron C3AN-2, and an age of approximately $4.0 \mathrm{Ma}$ is preferred for this biohorizon on the Vøring Plateau. The interpreted age of this boundary in Hole $642 \mathrm{C}$ is $4.5 \mathrm{Ma}$.

Age-diagnostic calcareous nannofossils are extremely rare in sediments below 100 mbsf in Hole 643A. Calcareous nannofossils in general are essentially absent in the 423-m-thick interval below Core 104-643A-16H, with the exception of $0.5 \mathrm{~m}$ of nannofossil chalk representing the only recovery in Core 104-643A$43 \mathrm{X}$, at a depth of $400.9 \mathrm{mbsf}$. Of the two samples from this chalk analysed for calcareous nannofossils, only the lower sample contains specimens of $D$. enormis. Assuming that the chalk is in place and represents the true extinction level of $D$. enormis, this biohorizon is the best indication of the Oligocene/Miocene in Hole 643A. Sediments assigned to Zones NN7-NN15 of Donnally occur immediately above a hiatus spanning the time interval from 8.8 to $13.7 \mathrm{Ma}$, and Zones NN7-NN9 of Martini (1971) are presumed to be unrepresented at Site 643. $R$. pseudoumbilica has its last recorded occurrence in Section 104-643A$9 \mathrm{H}-2$, but $P$. lacunosa is not recorded until Section 104-643$7 \mathrm{H}-5$, and it is concluded in this synthesis that the separation between Zones NN7-NN15 and NN16-NN19 ranges from 3.9 to $7.0 \mathrm{Ma}$ in Hole $643 \mathrm{~A}$, including hiatuses and unsampled intervals.

Calcareous nannofossils are more abundant, more consistently present, and better preserved in the interglacial and preglacial sediments in Hole $644 \mathrm{~A}$ than at the other sites. The bases of Zones NN21 and NN20 are the only biohorizons recognized in these sediments, and their ages are reasonably consistent with the ages assigned by Berggren et al. (1985).

\section{Benthic Foraminifers}

Benthic foraminifer assemblages exhibit pronounced changes in the sedimentary sections penetrated on Leg 104. In general, these foraminifers are well preserved but few in number in sediments younger than $2.0 \mathrm{Ma}$, where they compose only $10-20 \%$ of the total foraminifer assemblages. Below a barren interval, which ranges in thickness from $25 \mathrm{~m}$ in Hole $643 \mathrm{~A}$ to $35 \mathrm{~m}$ in Hole $644 \mathrm{~A}$, more diverse faunas of calcareous and sparse agglutinated tests comprising approximately $50 \%$ of the total foraminifer assemblages are intermittently present, but preservation has deteriorated to only moderate or poor. With the exception of a few thin chalk beds, specimens of calcareous benthic foraminifers are very rare or absent in sediments judged to be older than 13.6 Ma. Assemblages composed exclusively of agglutinated tests occur in the underlying strata at Sites 642 and 643. These various benthic foraminifer faunas were arranged in eight assemblage zones in Eldholm, Thiede, Taylor, et al. (1987b), designated A1, A2, B, C1, C2, D1, D2, and E. Zones A1 to B represented the younger, mixed calcareous and agglutinated assemblages, and the remaining five zones represented the older, exclusively agglutinated faunas. Nominate taxa associated with these letter zones varied from site to site.

Although never formally defined, Osterman and Qvale (this volume) retain this biozonation, which is reduced to seven zones. A standard set of generic or binomial names is proposed, zone A2 is redefined, some zonal boundaries have been readjusted significantly, and zones C2 and D1 are merged. Holes 642B, $642 \mathrm{D}$, and $643 \mathrm{~A}$ are studied in considerable detail, but the samples from Holes $642 \mathrm{C}$ and $644 \mathrm{~A}$ are less densely spaced. Letter designations are retained, and the same scheme will be followed here to facilitate comparison. Zone A1 represents the younger glacial-interglacial sediments at each site in which benthic foraminifers are relatively few in number. Cassidulina laevigata occurs with relative consistency, and Cibicides wuellerstorfi is found in the interglacial intervals. Full glacial sediments are characterized by abundant ice-rafted clastics and reworked foraminifers indicative of more shallow environments, of which Elphidium excavatum is particularly noted in Hole 644A. The presence of Stetsonia horvathi and Pyrgo murrhina in Hole 643A suggests depth-related faunal variation. Zone A1 faunas at Site 644 are rich in Oridosalis umbonatus, Cassidulina reniforme, and dwarf specimens of Elphidium. This zone can be recognized only in sediments younger than $0.7-0.9 \mathrm{Ma}$ at Sites 642 and 643 , respectively, and benthic foraminifers are either absent or extremely rare in the older Pleistocene intervals. In Hole 644A, zone A1 faunas are recognized to a depth of $205 \mathrm{~m}$ (judged to have an age of $2.2 \mathrm{Ma}$ ), and the barren interval at the base of this zone represents only $0.6 \mathrm{Ma}$ of sedimentation. Occasional dark glacial beds and dropstones are described in the sediments to a maximum depth of $230.5 \mathrm{mbsf}$, but sediments below 219 mbsf have a generally pre-glacial character with scattered nannofossil chalk beds. Preservation of benthic foraminifers resumes only in sediments below $238 \mathrm{~m}$, however

Although benthic foraminifers are more abundant and diverse in zone $\mathrm{A} 2$, there are many barren intervals. The assemblage is characterized by Melonis zaandamae, Epistominella exigua, and Cassidulina subglobosa. Osterman and Qvale (this volume) emend the basal boundary criterion for zone A2. The first occurrence of Cassidulina laevigata was proposed as the marker event for the base of zone A2 in Eldholm, Thiede, Taylor, et al. (1987b), but the base of this zone in Hole 642B (this volume) is lowered to a position $19 \mathrm{~m}$ below the first occurrence of $C$. laevigata, and it is now coincident with a pronounced upward increase in the abundance of $C$. subglobosa and declining frequencies of Cibicides and Uvigerina. These events are sharply defined in Hole 642B and occur $3 \mathrm{~m}$ below a local unconformity. In Holes $642 \mathrm{C}$ and 643A however, these events are less obvious, which may account in part for the diachrony of the zones A1/B boundary between Sites 642 and 643 (8.1 and 6.5 Ma, respectively).

Zone B is characterized by abundant occurrences of $E$. exigua, Cibicides, and Uvigerina. The base of this zone is not defined on the basis of biostratigraphic criteria, but is coincident 
with the lowest level where calcareous benthic foraminifers are preserved. At Site 642, this horizon occurs near the base of the short unconformity-bound calcareous sequence with a maximum age of 13.6 Ma. The sequence in Hole 643A in which calcareous microfossils are preserved with reasonable consistency terminates at the base of Core 104-643A-11 H (age estimate, 8.8 $\mathrm{Ma}$ ), yet calcareous benthic foraminifers are not reported at the extreme base of this sequence. Zone B faunas have their lowest occurrences approximately $1.5 \mathrm{~m}$ above the bases of the calcareous sections at each site, and consequently the base of this zone is highly diachronous (13.5 Ma at Site 642 and 8.7 Ma at Site 643).

Benthic foraminifers regarded as in place have not been found in the pyroclastic unit or the basement series at Site 642 , and Osterman and Qvale have not studied the basal $20 \mathrm{~m}$ of mudstones resting on basaltic conglomerate at Site 643. Assemblages composed of exclusively agglutinated species in the overlying section in Hole 643A are subdivided into three zones: C2, D, and E. Osterman and Qvale (this volume) designate new nominate taxa for the latter two zones. The oldest zone, $\mathrm{E}$ (unchanged stratigraphically in this volume), is represented by a diverse fauna dominated by Rhabdammina- and Rhizamminatype species and lesser frequencies of Cyclammina. Zone D (formerly zone D2) has fewer Rhabdammina representatives and is characterized by Haplophragmoides walteri and the continuing presence of Cyclammina. The barren interval separating this zone from the overlying zone in Eldholm, Thiede, Taylor, et al. (1987b) has been removed by Osterman and Qvale (this volume), and the top of zone D has been moved up $32 \mathrm{~m}$ to Core 104-643A-35X, CC.

With the exception of dinoflagellate biostratigraphy, there is no independent means of determining the ages of zones D and $\mathrm{E}$ in Leg 104 sediments, and numerical age estimates must be viewed with caution. King (1983) recognized Spiroplectammina spectabilis as a diagnostic middle Eocene species for the North $\mathrm{Sea}$, and the presence of this species in zone $\mathrm{E}$ and lower zone $\mathrm{D}$ may be indicative of a coeval age for this section in Hole 643A. If the last occurrence of $S$. spectabilis is accepted as an age criterion, then the Eocene/Oligocene boundary in Hole 643A would be raised to a position no lower than $440 \mathrm{mbsf}$, which is at least $115 \mathrm{~m}$ above the boundary horizon selected on the basis of dinoflagellate biostratigraphy presented in Manum et al. (this volume). Occurrences of $S$. spectabilis on the Vøring Plateau appear to be markedly influenced by facies associations, however, and the range of this species in Hole 643A may not have interregional age implications. $S$. spectabilis is rare and sporadic in Hole $643 \mathrm{~A}$, whereas it is common and has an abrupt last occurrence at the Eocene/Oligocene boundary in Hole 647A in the Labrador Sea. In the North Sea Central Graben, it is less common and disappears within the middle Eocene/upper Eocene succession (Kaminski, 1988). Palynologic criteria were also preferred for assignments of series boundaries in Eldholm, Thiede, Taylor, et al. (1987b), but Paleogene series boundaries there proposed for Hole 643A are not retained in this volume by Manum et al. A compromise between these divergent lines of biostratigraphic evidence will be proposed in the Paleogene Biostratigraphy section.

The top of zone D is now approximately $63 \mathrm{~m}$ above the Oligocene/Miocene boundary as inferred on the basis of calcareous nannofossil biostratigraphy. The presence of typically $\mathrm{Ru}-$ pelian (lower Oligocene) calcareous benthic foraminifers such as Turrilina alsatica and Anomalinoides in the 0.5 -m-thick chalk bed representing the only recovery in Core 104-643A-43X would support the placement of the Oligocene/Miocene boundary at a position no lower than this horizon. The occurrence of these species only in the lower portion of the chalk bed is not in contradiction with this boundary assignment, although $T$. alsatica has its last occurrence in lower Oligocene sediments of the North Sea and Labrador Sea (Kaminski, 1988).

The sparse assemblages of zone $\mathrm{C} 2$, which are dominated by species of Spirosigmoilinella and Spirolocammina, range up to the base of zone B in Hole 643A. Interestingly, there is no significant faunal change associated with the abrupt lithologic contact between Cores 104-643A-29X and -643A-30X, where the older flysch deposits are replaced by pelagic ooze. Zone $\mathrm{C} 2$ assemblages are the oldest benthic foraminifers recorded at Site 642 , and they range to the base of the siliceous mud section having a basal age judged to be $22.0 \mathrm{Ma}$.

The first occurrence of Martinottiella communis, an agglutinated species apparently restricted to shallow depths on the Vøring Plateau during Miocene time, is proposed as the basal marker event for a nominate partial-range zone (letter designation C1) in Leg 104 sediments. This zone occurs only at Site 642 , where its base is approximately coincident with a local unconformity. The presence of this hiatus, as well as poor preservation and low-density sampling in Hole $642 \mathrm{C}$, pose problems for confident recognition of the base of zone $\mathrm{C} 1$. The first occurrence of $M$. communis in Core 104-642B-23X is regarded as the best indication of its proper position, and the base of zone $\mathrm{C} 1$ is judged to have an age of $15.5 \mathrm{Ma}$.

Kaminski (1988) included the 182.7 -m-thick succession in Cores $104-643 \mathrm{~A}-41 \mathrm{X}$ to $-643 \mathrm{~A}-62 \mathrm{X}$ as part of the extensive data base analysed in his study of North Atlantic agglutinated benthic foraminifers. On the basis of stratigraphic range data on 50 taxa, Kaminski recognized five Paleogene assemblage zones at this site (Fig. 11, this chapter) that have important implications for Leg 104 biostratigraphy. Because this doctoral dissertation is being prepared for publication elsewhere, a more thorough summary is not attempted here, but specific aspects of these results are further discussed in the Series/Subseries Boundaries and $\mathrm{Pa}-$ leogene Biostratigraphy sections.

\section{Planktonic Foraminifers}

Because of the absence of temperate and tropical species whose ranges have been used as boundary criteria for established biozonations, it has been necessary to formulate a new local biozonation for Leg 104 planktonic foraminifers. The scheme proposed by E. Jansen in Eldholm, Thiede, Taylor, et al. (1987b) is an early manifestation of this effort. The ranges of three Neogloboquadrina species were used to partially define four zones. The last occurrences of $N$. continuosa and $N$. atlantica, and the first occurrence of encrusted sinistrally-coiled $N$. pachyderma marked the tops of zones NSPF3 to NSPF5, respectively. The latter event also served as the marker for the base of the Pleistocene. Zone NSPF6 included all sediments younger than NSPF5. As with the benthic foraminifers, the base of zone NSPF3 coincided with the base of the calcareous sequence (interpreted age, 13.6 Ma). These zones could be applied to Sites 642 and 644, but only NSPF6 could be confidently correlated to Hole 643A. On the basis of uncertain identifications of fragmented globigerinid specimens extracted from the scattered lithified chalk beds in Hole 643A between 390 and 485 mbsf, two additional zones were proposed: NSPF1 (regarded as middle to late Eocene) and NSPF2 (regarded as late Eocene to late Oligocene). Spiegler and Jansen (this volume) present a much different biostratigraphic system, and only one of the original NSPF zones is retained (NSPF6, now bearing the name of its basal marker). Although encrusted sinistrally-coiled $N$. pachyderma has its advent level in the late Pliocene and has somewhat diachronous distributions in Leg 104 sediments, the first abundant occurrence of this species has been accepted as an approximation of the Pleistocene/Pliocene boundary. Stratigraphic range data on 18 planktonic foraminifer species and variants are presented, and the distributions of intervals barren of these microfossils 
are carefully documented. Seven zones are proposed for the calcareous sequence younger than $13.6 \mathrm{Ma}$., and older occurrences of individual species (Globigerinoides trilobus, Neogloboquadrina nana/N. continuosa, and $N$. ?peripheroronda) are noted. The oldest occurrences of planktonic foraminifers in Hole 643A (formerly NSPF1 and NSPF2) are discussed briefly, but not treated as formal zones, and the age of the younger of these units is emended to Oligocene.

Boundary criteria for the six youngest zones are based exclusively on the first appearances and subsequent coiling direction changes of three Neogloboquadrina species: $N$. acostaensis, $N$. atlantica, and $N$. pachyderma. Assemblages from the lower portion of the calcareous sequence at Site 642 , which include $N$. mayeri but lack $N$. acostaensis, are referred to the $N$. mayeri Assemblage. Particularly noteworthy in this new scheme is the presence of two zones characterized by $N$. atlantica (dex.), which are separated by the $N$. atlantica (sin.) Zone. The younger of these two homonomial zones spans the time interval from 1.8 to 2.3 Ma (interpreted), and it has been recognized only in Hole 644A. Coeval sediments at Sites 642 and 643 are barren or missing, respectively. Thus, the upper $N$. atlantica (dex.) zone of Site 644 is younger than the $N$. atlantica Zone of Weaver and Clement (1986) and even younger than the $2.3 \mathrm{Ma}$ age for the top of the zone as proposed by Aksu and Kaminski (in press) at Site 646 in the Labrador Sea.

Specimens of $N$. acostaensis from the base of the nominate zone at Site 642 have test morphologies characteristic of this species at an evolutionarily young stage. Therefore, the base of the $N$. acostaensis Zone at Site 642 has been assigned an age of 10.2 Ma., the maximum age attributable to $N$. acostaensis by Berggren et al. (1985). The base of this zone is taken as the middle Miocene/upper Miocene boundary, which coincides with the top of a large hiatus at Site 642 and is missing in the hiatus at Site 643. The briefly overlapping ranges of $N$. mayeri and $N$. acostaensis in Hole $642 \mathrm{C}$ may be an indication of reworking in the base of the sequence overlying this unconformity of probable regional magnitude.

Fine-scale correlation by means of this scheme is precluded by the numerous intervals characterized by poor preservation or absence of planktonic foraminifers, and such intervals separated most of the zones in each hole. Nevertheless, this investigation of planktonic foraminifers has made an important contribution to Leg 104 biostratigraphic analysis because the zonal boundary criteria can be correlated with limited precision to localities in the more temperate North Atlantic. By these means, Spiegler and Jansen (Fig. 9, backpocket) inferred that the $N$. atlantica (sin.) Zone should span the time interval from approximately 2.3 to ca. $6.0 \mathrm{Ma}$ and include portions or all of Chrons $\mathrm{C} 2 \mathrm{~A}$ to $\mathrm{C} 3 \mathrm{~B}$. The polarity reversal record for younger chrons is reasonably complete in Holes $642 \mathrm{~B}$ and $642 \mathrm{C}$, and the identification of all or portions of chrons $\mathrm{C} 2 \mathrm{~A}, \mathrm{C} 3$, and $\mathrm{C} 3 \mathrm{~A}$ in these recoveries is supported by this planktonic foraminifer correlation. This is the youngest reported age in the Atlantic for the base of the $N$. atlantica (sin.) Zone. Aksu and Kaminski (in press) demonstrate the diachrony of this zone, which is probably a function of water masses. The coiling change occurred earliest in the cold waters of the East Greenland Current (ca. 8.6 Ma; Aksu and Kaminski, in press), later on the Rockall Plateau (ca. 7.0 Ma according to Keigwin, 1987) and is reported at around $6.5 \mathrm{Ma}$ in the eastern North Atlantic (Weaver and Clement, 1987). The $N$. atlantica (dex.) Zone is best represented in Hole $642 \mathrm{~B}$, where it ranges in age from ca. $6 \mathrm{Ma}$ to $8.8 \mathrm{Ma}$.

\section{Ostracodes}

Ostracodes were not reported in sediments recovered from DSDP Leg 38, and occurrences of these microfossils in Leg 104 sediments were only cursorily noted in Eldholm, Thiede, Taylor, et al. (1987b; pp. 128, 129, 477, and 632). No biozonation is attempted because of their very rare to sparse occurrences in Leg 104 sediments. Only 119 specimens (mostly juveniles) were found in 60 of the 1157 samples searched by Malz (this volume), and the majority of these finds were single-specimen occurrences. A total of 30 taxa (including described species and forms in open nomenclature) are reported for Hole 642B down to Section 104642B-19H-1 (age estimate $=10.0 \mathrm{Ma}$ ). Both diversity and frequencies of occurrence show generally increasing trends with decreasing age. The new finds reported by Malz extend the stratigraphic ranges of many of these extant species back to the Pliocene and late Miocene in this high-latitude region.

\section{Palynomorphs}

Palynomorph biostratigraphy is particularly important in highlatitude regions such as the Vøring Plateau, where other age-diagnostic microfossils are frequently rare or absent. Consequently, this subject received a great deal of effort by P. Mudie during Leg 104, despite the limited laboratory facilities and time available for sample preparation. Palynomorphs, including dinoflagellate cysts, pollen, spores, and palynodebris, were the most extensively reported biostratigraphic subject of Eldholm, Thiede, Taylor, et al., (1987b). A total of 70 species were treated, and the ranges of many of these taxa as well as palynodebris were figured for core-catcher samples from Sites 642 and 643, and Site 644 was analysed in lesser detail. A system of six informallynamed Neogene assemblage zones (designated PM1 to PM6) was tentatively proposed for Site 642 , based on single or multiple species boundary criteria. Each zone was described in detail and correlated with localities in the North Atlantic, where frequently the ranges of critical species could be associated with polarity reversal ages. Three additional zones were tentatively proposed for the Paleogene of Site 642: PM7 (late Eocene) for the pyroclastic interval, and PM8 and PM9 (late middle Eocene and late early to late middle Eocene, repectively) based on specimens extracted from 26 intercalations in the basalt series recovered in Hole 642E. The series/subseries assignments for these intervals were based on palynostratigraphy. The biozonation proposed for Site 642 was not easily applicable at Sites 643 and 644 . The boundary criteria for zones PM2-PM5 were not recognized at Site 643 , or they did not occupy the same sequential position as at Site 642 . The base of zone PM6 was placed at 410 mbsf, which is $58 \mathrm{~m}$ below the level of its boundary criterion and $38 \mathrm{~m}$ below the level of the boundary criterion for the top of zone PM8. The latter zone was not recognized at Site 643 . Zone PM7, interpreted as late Eocene at Site 642, is divided into two subzones in Hole 643A. The younger subzone, PM7a, is assigned a late Oligocene age, despite the fact that it includes the total range of the basal boundary criterion of zone PM7. Subzone PM7b (late Eocene) is based on taxa not observed at Site 642 . Only short taxa lists were provided for nine samples from Hole $644 \mathrm{~A}$, but many of the critical species necessary for the differentiation of zones PM1b and PM2 were not observed, and the base of the hole was provisionally assigned to PM3 (Miocene) in opposition to paleomagnetic and other biostratigraphic evidence supporting a late Pliocene age.

Analyses of the Pleistocene and Pliocene intervals from all three sites have been undertaken by Mudie (this volume), who additionally has investigated the upper $167 \mathrm{~m}$ of Hole 642B. A detailed investigation of Miocene and older sediments in Hole $643 \mathrm{~A}$ is presented by Manum et al. (this volume), who additionally report on Hole 642D and the lower part of Hole 642C. Palynomorphs from only the base of the lower basalt series in Hole $642 \mathrm{E}$ are reported by Boulter and Manum (this volume), and regrettably there is no documentation of the taxa identified from numerous samples of the upper basalt series (by Mudie in Eldholm, Thiede, Taylor, et al., 1987b). Stratigraphic ranges for 
the same species in Hole $643 \mathrm{~A}$ given in that report and by Manum et al. (this volume) differ markedly.

A biozonation including 15 units is employed by Manum et al. (this volume) for the Paleogene to upper Miocene sediments of Hole 643A. The two youngest zones (Impagidinium aquaeductum and Achomosphaera andalousiensis) are adopted from Piasecki (1980), but other units from established biozonations were not applicable because boundary criteria taxa were not found in Hole $643 \mathrm{~A}$. The remaining zones are proposed as new and include eight Paleogene units (Rottnestia borussica to Systematophora sp. 1) and five lower to middle Miocene units (Ascostomocystis granosa and Labyrinthodinium truncatum). Most of these consecutive zones are separated by intervals as much as $25 \mathrm{~m}$ thick that are either barren or unsampled, and the thickness of these intervals appears to increase in the Neogene succession.

The biostratigraphic event recognized by Williams and Bujak (1985) for the top of the Oligocene series, the last occurrence of Chiropteridium partispinatum, occurs in the top of Core 104643A-44X, and Miocene dinocysts are found in Core 104-643A$42 \mathrm{X}$ (the intervening sediments are missing or barren). Consequently, the dinocyst biostratigraphy is consistent with assignment of the Oligocene/Miocene boundary at $410 \mathrm{mbsf}$ on the basis of nannofossil evidence. The biostratigraphic range data for individual dinocyst species presented by Williams and Bujak (1985) have been used extensively by Manum et al. (this volume) to determine the ages of their Paleogene zones. The oldest zone, $R$. borussica, occurs $10 \mathrm{~m}$ above the bottom of the Hole $643 \mathrm{~A}$, but its precise age is indiscernible. The oldest sediments that can be confidently dated are from the Adnatosphaeridium vittatum Zone, which is regarded as middle Eocene, and the age of the $R$. borussica Zone is given as ?early to middle Eocene. No dinocysts characterized by ranges restricted to the late Eocene have been found in Hole 643A, and sediments of late Eocene age are regarded as missing.

The Evittosphaerula paratabulata Zone and younger zones have been recognized at both Sites 642 and 643, and the distributions of the zones at these two localities offer some interesting comparisons (this chapter, Figs. 7-8). The Neogene dinocyst zones are not precisely correlative between the two sites, because of the broad unsampled intervals mentioned above. For example, the $A$. andalousiensis Zone does not have coeval occurrences ( 4.8 to $5.9 \mathrm{Ma}$ in Hole $642 \mathrm{C}$ and 6.9 to ?8.7 Ma in Hole $643 \mathrm{~A}$ ), which is partially explained by the unsampled intervals. The zones above the Emslandia spiridoides Zone appear to be younger in Hole 642C than in Hole 643A. The situation reverses however, for the the zones below the Labyrinthodinium truncatum Zone, which appear to be consistently younger in Hole 643A. The most extreme case is the base of the Impagidiniumpatulum Zone, which occurs near the bottom of the siliceous ooze unit in Hole 643A (interpreted age, 18.4 Ma) and has been found in the upper part of the pyroclastic unit in Hole 642D (interpreted age, 22.0 Ma). A possible explanation for this discrepancy is presented in the Paleogene Biostratigraphy section. Allowing for the unsampled intervals in the two holes, the age of the top of the I. patulum Zone is probably $17.2 \mathrm{Ma}$. Taking the two holes as a composite, the Emslandia spiridoides Zone occupies the age interval of 15.7 to $17.2 \mathrm{Ma}$, and the $L$. truncatum Zone occupies an age interval of 14.4 to $15.1 \mathrm{Ma}$.

Manum et al. (this volume) report the sporadic occurrence in Hole 643A sediments of pollen and spores bearing evidence of variable transport distances. The contact between two distinct vascular plant assemblages is approximately coincident with the Oligocene/Miocene boundary. Land plant assemblages above Section 104-643A-42X-1 are uniform in composition and are dominated by Pinaceae pollen, with relatively limited angiosperm representatives. Floras below Section 104-643A-42X-4 are also uniformly composed, but differ by the presence of an abundance of monosaccate pollen with a large marginal frill or velum. Although known from other Paleogene localities, this species is not present in younger sediments in Hole 643A.

Mudie (this volume) reports briefly on a palynological investigation of 600 samples from Holes 642A, 642B, 642C, 643A, 644A, and 644B. This study is confined to the Neogene, and no new data are presented on the palynology of the basalt series of Site 642. As in Eldholm, Thiede, Taylor, et al. (1987b), boundary criteria are defined for both the tops and bottoms of the five zones now employed by Mudie, and these criteria appear to differ from site to site. The three oldest zones of Mudie (this volume), the Emslandia spiridoides Zone (PM5), Impagidinium aquaeductum Zone (PM4) and Achomosphaera andalousiensis Zone (PM3), bear the same names as those of Manum et al. (this volume), but the reader is cautioned that these zones are not consistently defined by these authors and consequently do not represent the same biostratigraphic units. The I. aquaeductum Zone of Mudie includes both the I. aquaeductum and Labyrinthodnium truncatum Zones of Manum et al. (this volume). The contact between the $E$. spiridoides and $I$. aquaeductum Zones is defined by first occurrences of: $I$. aquaeductum, L. truncatum, and Cyclopsiella elliptica. The contact between the $I$. aquaeductum and $A$. andalousiensis Zones is not defined by the first occurrence of $A$. andalousiensis but by the first occurrences of Amiculosphaera umbracula and Hystrichosphaeropsis ?pontiana and the last occurrence of $I$. aquaeductum. The contact between the $A$. andalousiensis and Filisphaera filifera Zones is defined by first occurrences of $F$. filifera and Tectatodinium pellitum and the last occurrence of Nematosphaeropsis lemnisata. As it is here redefined, the base of the $F$. filifera Zone (PM2 of this volume, formerly PM 1b of Eldholm, Thiede, Taylor, et al., 1987b) is best represented in Hole 642B, where it has a basal age of $3.8 \mathrm{Ma}$. The youngest unit, the Multispinula minuta/Brigantedinium simplex Zone (PM1, formerly PM1a), is here defined by terminations of three highly discontinuous species and has a basal age of $0.7-0.8 \mathrm{Ma}$.

Some interesting paleoenvironmental deductions are made by Mudie (this volume) on the basis of frequency variations of palynomorph assemblages, palynodebris, and reworked dinocysts in this extensive data base, and fluctuations in these parameters are inferred to indicate glacial cycles in the Pliocene/ Pleistocene and possibly productivity cycles in the older sediment.

Boulter and Manum (this volume) conduct a palynological examination of 12 samples from the lower basalt series of Cores $104-642 \mathrm{E}-102 \mathrm{R}$ to $-642 \mathrm{E}-109 \mathrm{R}$ and report the presence of a flora similar to that occurring at other localities of the North Atlantic Volcanic Province. These authors employ the term Brito-Arctic Igneous Province Flora to characterize this phytogeographic association. Pollen and spores are dominant in the assemblages of these shale intercalations and consist of a flora very similar to that found in coeval sediments from the Rockall Plateau, eastern Greenland, Svalbard, the Faeroes, Northern Ireland, and western Scotland. Vascular plant megafossils from the majority of these localities have been interpreted as representative of a small pioneer flora that extended at least $2,000 \mathrm{~km}$ in the northern-most North Atlantic proximal to the axis of incipient rifting during calcareous nannofossil Zone NP9-NP10 time. These fossil plants are interpreted as indicative of mixed coniferous/primitive angiosperm forests that occupied the poor soils of nearshore environments, while ferns and taxodiaceous trees grew in freshwater swamps frequently invaded by shallow seas. The sparse dinocyst assemblage is assigned to the upper Apectodinium hyperacanthum Zone, which is regarded as earliest Eocene in age. These latter findings are further discussed in the Paleogene Biostratigraphy section. 


\section{Diatoms}

Extensive use was made of diatoms for both biostratigraphy and paleoenvironmental interpretation by Ciesielski in Eldholm, Thiede, Taylor, et al. (1987b). Three partially emended Pliocene/ upper Miocene zones proposed by Baldauf (1984) for the Rockall Plateau (the Nitzschia porteri-Nitzschia miocenica, Thalassiosira convexa, and Nitzchia jouseae Zones) and 10 zones and subzones described by Barron (1985a) for the North Pacific (NNPD1-NNPD8) were recognized at Site 642. A hiatus during the interval 8.7-11.2 $\mathrm{Ma}$ at $131 \mathrm{mbsf}$ in Hole $642 \mathrm{~B}$ and 136 mbsf in Hole $642 \mathrm{C}$ was inferred largely on the basis of diatom range data, but this interpretation has not been adopted in this synthesis chapter. Assuming the basal ages of Site 642 cores shown in Figure 9 (backpocket), are correct, then the ages for the bases of the $N$. porteri- $N$. miocenica, $T$. convexa, and $N$. jouseae Zones as shown in Eldholm, Thiede, Taylor, et al. (1987b), Site 642, Fig. 47, are in reasonable agreement with Baldauf (1984) (see Fig. 10, backpocket). Ages for the bases of Zones NNPD4b, NNPD5, and NNPD8 are closely comparable to the ages assigned to these boundaries by Barron (1985a). The bases of Zones NNPD6 and NNPD7 as shown in Figure 10 are 1.8 and 1.2 m.y. younger, respectively, than those of Barron (1985a).

The diatom biostratigraphy of Hole $643 \mathrm{~A}$ is closer to the interpretation adopted in this synthesis. Two major hiatuses were proposed for the succession recovered in this hole. The hiatus ranging from NNPD5c to NNPD6a (7.6-11.2 Ma according to Barron, 1985b) proposed for Core 104-643A-12H is in approximate agreement with the major middle Miocene hiatus of Figure 7 (8.8-13.7 Ma). A second hiatus ranging from upper NNPD3 to NNPD4 (14.6-16.5 Ma) was recognized in Core 104-643A$15 \mathrm{H}$, and this age interpretation may be more correct than the short hiatus in this core shown in Figure 7 ( 0.3 m.y. duration). Upper Miocene sediments at Site 643 were not assigned to the zones of Baldauf (1984) because the boundary criteria taxa were not observed, and instead the Coscinodiscus marginatus, Denticulopsis hustedti, and Cymatosira bihariensis Zones of Schrader and Fenner (1976) were recognized, although ages of these sediments (5.7-8.8 Ma according to Fig. 9, backpocket) are somewhat older than the ages assigned to these zones in Figure 11 (ca. 5-6 Ma).

Only limited diatom biostratigraphy was possible in the sporadically biosiliceous interval of Hole 644A. The lower part of NNPD11 was recognized below the upper barren interval, and a single composite zone (NNPD8-NNPD10) characterized the remaining older sediments.

With the exception of range termination data for 19 diatom taxa in Holes $642 \mathrm{C}, 642 \mathrm{D}$, and $643 \mathrm{~A}$ presented by Ciesielski and Case (this volume), no new studies of Leg 104 diatoms are included in this volume. Interesting among these more recent data is the stratigraphic position of the five simultaneous events (last occurrences of Coscinodiscus plicatus, C. yabei, and Denticulopsis lauta; first occurrences of Rhizosolenia barboi and Nitzschia miocenica), upon which the inference of an upper Miocene unconformity was based (Fig. 10, backpocket). These events now represent a point cluster approximately $6 \mathrm{~m}$ higher in Hole $642 \mathrm{C}$ than originally indicated, and they are approximately coeval with corresponding events in Hole 643A. Additionally, they are isochronous with the pronounced surface water temperature decline indicated on the basis of silicoflagellate data by these authors as well as Locker and Martini (this volume). With the exception of Craspedodiscus coscinodiscus, the ages for the five events occurring in the thin sedimentary sequences represented by lower Core 104-642C-19H to upper Core 104-642C-20H and the upper part of Core 104-643A-12H provided by Ciesielski and Case (12.9-13.9 Ma) confirm the age range assigned to this sediment in Figure 9 (backpocket, 13.4-13.7 Ma). The first oc- currences of Denticulopsis hustedti, D. hustedtii punctatum, D. hyalina, and $D$. lauta in Hole 642 are roughly correlative with corresponding events in Hole 643A, although they occur in sediments interpreted in this synthesis as different sequences (Fig. 9, backpocket). The ages of these events based on their stratigraphic position in Holes $642 \mathrm{C}$ and $643 \mathrm{~A}$ are within approximately $1 \mathrm{~m} . \mathrm{y}$. of the ages indicated by Ciesielski and Case (this volume). The first occurrence of $A$. ingens in Hole 643A is lowered $57 \mathrm{~m}$ below the depth indicated in Eldholm, Thiede, Taylor, et al. (1987b), and there is a 2-m.y. disparity between the ages of this event at Sites $642(15.5 \mathrm{Ma})$ and $643(17.5 \mathrm{Ma})$, if Figure 9 is correct. Barron (1985b) indicated an age of $15.5 \mathrm{Ma}$ for this event in the equatorial Pacific.

\section{Ebridians and Actiniscidians}

The stratigraphic ranges of 53 species and informal morphs of ebridians and actiniscidians have been recorded from Holes $642 \mathrm{C}, 642 \mathrm{D}$, and $644 \mathrm{~A}$ by Locker and Martini (this volume). These floras have been divided into a system of nine zones, of which all but two of the youngest units are new. With only a few exceptions, the stratigraphic ranges of ebridians and actiniscidians have not been documented for other localities outside the Norwegian Sea, where they can be compared to standard biozonations or paleomagnetic records. Such comparisons are available only for the Ebriopsis cornuta and Ammodochium serotinum Zones, which appear to be correlative from the northern North Pacific to the Norwegian Sea. It is anticipated that ebridians and actiniscidians will have increasing biostratigraphic importance as our knowledge of these floras advances.

The seven broad zones of the Miocene and Pliocene have durations of 0.6 m.y. to 4.2 m.y., and these ebridian/actiniscidian floras do not appear to have been influenced by the numerous sedimentary disruptions inferred for this interval. Ebridian diversities peaked in the Hermesinum adriaticum Zone (15.6-18.7 Ma) with 13 to 15 taxa, and diversities began declining sharply in the Parathranium clathratum Zone (5.3-8.8 Ma). Actiniscidian diversities reached their highest levels (five taxa) in the Spongebria miocenica Zone (14.3-15.4 Ma) and Hermesinella schulzii Zone (8.8-14.3 Ma.), and diversities declined abruptly in younger sediments. Ebridians disappeared in Leg 104 sediments younger than 1.9 Ma., and only two actiniscidian species persisted into the Pleistocene of Site 644.

\section{Radiolarians}

The provisional Neogene biozonation (zones NSR1-NSR13) employed by Goll and Bjørklund in Eldholm, Thiede, Taylor, et al. (1987b) was based primarily on previous studies of DSDP Leg 38 radiolaria. There are no Leg 38 siliceous successions coeval with portions of the Leg 104 holes, however, and additional biozones were proposed based on undescribed species. The sporadic occurrences of many of the boundary-criteria taxa are now documented as a result of subsequent more detailed investigations, and the diachronous nature of some of these zones is now apparent (particularly zones NSR 3-NSR 6). Goll and Bjørklund (this volume) reject this previous scheme and propose a new biozonation including 28 zones and subzones. Two short intervals 2.8 and $6.0 \mathrm{~m}$ thick in the lower Miocene and middle Miocene have not been characterized biostratigraphically, and they are termed Interzones A and B, respectively. Cenozoic radiolarian assemblages of the Norwegian Sea are composed largely of highlatitude endemic species as well as lesser numbers of slowlyevolving cosmopolitan species. Biostratigraphic range data are presented for a total of 55 species. Radiolarians selected as index species for the present biozonation are primarily indemic and short ranging, and there are few opportunities for inter-regional correlation. Radiolarians have been very useful for highresolution correlations of the three Leg 104 sites, however, and 
the locations of most of the hiatuses depicted in Figure 9 (backpocket) are based on radiolarian data. Long-ranging species, such as Hexalonche ?naka and Siphocampe arachnea, undergo pronounced fluctuations in frequencies of occurrence in Leg 104 successions.

The first occurrence of Ceratocyrtis manumi has been selected as the marker event for the lower Miocene/middle Miocene boundary, and the last occurrence of Liriospyris cricus has been selected as the marker event for the Miocene/Pliocene boundary. By comparing the fauna of the Actinomma henningsmoeni Zone of Hole 642D with DSDP sediments from the equatorial Pacific, it has been possible to determine that this zone is approximately coeval with the middle of the Cyrtocapsella tetrapera Zone and has an age of about $22 \mathrm{Ma}$. Similarly, the Gondwanaria japonica kiaeri Zone of Holes 642D and 643A is approximately coeval with the middle of the Stichocorys delmontensis Zone and has an age of about $20 \mathrm{Ma}$.

Some of the new zones proposed for Leg 104 sediments are reported for Sites 338,341 , and 348 . On these bases, the authors contest the correlation of Subsynthem 1.6 proposed in the present synthesis. Otherwise, radiolarian biostratigraphy is in close accord with the synthemic system. An association is suggested between hiatuses and episodes of rapid evolution.

\section{Silicoflagellates}

A composite biostratigraphic system of seven Neogene zones including both Norwegian Sea and modified Antarctic units was employed by Ciesielski to characterize Leg 104 silicoflagellate floras in Eldholm, Thiede, Taylor, et al. (1987b). Unfortunately, the core-catcher samples from Holes 642B, 642C, and 642D were integrated into a single composite section based on depth alone, and species ranges derived by this method may be unreliable. Moreover, there appears to have been some confusion concerning the order of first appearances of index taxa. Numerical ages inferred for the boundaries of the younger zones are not consistent with ages assigned to these sediments in Figure 9 (backpocket). The presence of Distephanus crux and Mesocena apiculata in a single sample from the upper basement series were used to fix the maximum age of Core 104-642E-35R at approximately $42 \mathrm{Ma}$. No documentation of these occurrences is presented in this volume.

Two alternative biozonations for Leg 104 silicoflagellates are presented by Ciesielski, Hasson and Turner (this volume) for Holes 642C, 642D, 643A, and 644A and Locker and Martini (this volume) for Holes $642 \mathrm{C}, 642 \mathrm{D}$, and 644A. Hole 642B is not treated in either contribution. Ciesielski, Hasson and Turner (this volume) employ a system of 12 units, including three tropi$\mathrm{cal} /$ temperate Naviculopsis Zones and six new zones and subzones: Distephanus speculum hemisphaericus, Caryocha ernestinae, Bachmannocena circulus var. apiculata/Caryocha, Distephanus crux scutulatus, Bachmannocena diodon nodosa, and Distephanus jimlingi (subzones a and b). Emendations are proposed for the Distephanus boliviensis and Distephanus speculum Zones. On the basis of comparisons with Site 409 on the Reykjanes Ridge, the Naviculopsis lata Zone of Cores 104$642 \mathrm{D}-9 \mathrm{X}$ to $-10 \mathrm{X}$ is correlated with calcareous nannofossil zone $\mathrm{NN} 1$ and paleomagnetic Chron C6B-C6C, although these cores are indicated as younger than $22.0 \mathrm{Ma}$ in Figure 9 (backpocket). The last occurrence of Naviculopsis is the boundary criterion for the top of the $N$. ponticula Zone, which the authors regard as occupying a position near the top of calcareous nannofossil zone NN4. The middle of zone NN3 appears to be a more realistic age for this bioevent in the Norwegian Sea, however. The age of $13.7 \mathrm{Ma}$, inferred for the very short Caryocha ernestinae Zone, is within the range of reasonable error for the age assigned to this bioevent in Figure 9 (backpocket), allowing for coarse sampling and barren intervals. The unconformable base inferred for the $C$. ernestinae Zone is consistent with the radiolarian evidence, and a small hiatus is shown at this position in Figure 9. A large hiatus is inferred for the base of the $B$. circulus var. apiculata/Caryocha Zone because of the numerous coincident last occurrences observed at this horizon. The base of this zone is located in the thin sedimentary sequence below this unconformity (Subsynthem NSN 1.6, see the Neogene Biostratigraphy section) at Sites 642 and 643 . The actual position of these last occurrences may occur within the major hiatus in Hole $642 \mathrm{C}$, because of the coarse sample spacing employed by these authors. This zone is positioned below the unconformity at Hole 643A, but the slump and debris flow deposits of Core 104-643A-12 H may account for this discrepancy. The Distephanus crux scutulatus Zone appears to be diachronous between Sites 642 and 643 . The Miocene/Pliocene boundary is regarded to lie in or near Section 104-642C-15H-5 on the basis of the single occurrence of Neonaviculopsis neonautica at the top of the $B$. diodon nodosa Zone, but this biohorizon is assigned an age of approximately $6.0 \mathrm{Ma}$ in this synthesis on the basis of paleomagnetic and other biostratigraphic evidence.

Ciesielski and Case (this volume) interpret the relative temperatures and fertility of Neogene surface currents flowing across the outer Vøring Plateau, based on the relative frequency of occurrence of seven silicoflagellate taxon groups in Holes $642 \mathrm{C}$, $642 \mathrm{D}$, and $643 \mathrm{~A}$. High relative frequencies of occurrence of Dictyocha (extant), Naviculopsis (extinct), and quadrate Distephanus (extinct) are inferred to indicate temperate-tropical seasurface temperatures, whereas high relative frequencies of hexagonal Distephanus (extant) are inferred to indicate polar-subpolar temperatures. High relative frequencies of Bachmannocena (extinct), Corbisema (extinct), and Caryocha (extinct) are regarded as indicative of high-nutrient concentrations in the photic zone. Plots of these parameters vs. depth are presented for Sites 642 and 643 , but it is important to note that the chronostratigraphy applied by these authors differs by as much as 3 m.y. from that of this synthesis. The quadrate Distephanus curves of Ciesielski and Case are replotted in Figure 9 (backpocket) on the basis of core ages accepted in this synthesis, and these results are further discussed in the Paleoenvironments section.

Locker and Martini (this volume) also investigate the silicoflagellate biostratigraphy of Holes 642C, 642D, and 644A. These authors adopt the six silicoflagellate zones formerly recognized in DSDP Leg 38 sediments by Martini and Müller (1976), with the addition of a new zone (Mesocena diodon), inclusion of two subzones (Distephanus stauracanthus and Mesocena quadrangula), and division of the Corbisema triacantha Zone into upper and lower units. The Distephanus boliviensis Zone has emended nomenclature. These zonal units can be recognized in high latitudes of both hemispheres. Seven new taxa are described. Range terminations (bioevents) in Leg 104 sediments of 11 taxa regarded as having particular correlation potential are compared to Leg 38 sites and localites from other regions. Relative frequencies of occurrence of nine genera and morphologic groups in samples from Site 642 are treated statistically, and a well-established formulation is employed to convert these data into a silicoflagellate paleotemperature curve depicting ten Neogene cooling cycles. This curve is replotted in Figure 9 (backpocket) and further discussed in the Paleoenvironments section. Although temperature adaptations attributed to silicoflagellate taxa by Locker and Martini (this volume) differ somewhat from those of Ciesielski and Case (this volume), the general trend of the present curve is similar to some of the figures presented by the latter authors.

\section{SERIES/SUBSERIES BOUNDARIES}

With few exceptions, species whose range terminations are conventionally employed to recognize Cenozoic series and sub- 
series boundaries in more temperate regions do not occur in Norwegian Sea sediments. Consequently, it is necessary to choose unique criteria for this region that most closely approximate the ages of these chronostratigraphic units elsewhere. The criteria selected for Leg 104 reflect facies associations. Neogene boundary criteria are based on calcareous and siliceous plankton, whereas the Paleogene siltstones and shales must be characterized by agglutinated foraminifers and palynomorphs. The eight divisions in Eldholm, Thiede, Taylor, et al. (1987b), their boundary recognition critieria, and the positions of these boundaries in each hole are shown in Table 1. As our knowledge of Leg 104 biostratigraphy and magnetostratigraphy advanced during the course of these many diverse investigations, it has become advisable to emend five of these boundary criteria as well as to select a marker event for the lower Eocene/middle Eocene boundary. These new criteria and hole positions are also shown in Table 1. The availability of biostratigraphic data in each hole in which the requisite boundary occurs has been an important consideration in the selection of event markers. Actiniscidians, diatoms, ebridians, and silicoflagellates have not been regarded as candidates for boundary criteria for this reason, although many of these species have been important for correlation, particularly in the middle-to-lower Miocene.

In Eldholm, Thiede, Taylor, et al. (1987b), the first occurrence of Neogloboquadrina pachyderma (sin.-encrusted) was accepted as the basal Pleistocene marker, but this convention has been modified on the basis of more detailed studies. Upper Pliocene sediments in Leg 104 holes contain populations of $N$. pachyderma bearing a broad range of morphologies, including N. pachyderma (sin.-encrusted, s.s.). Moreover, the first occurrence of this latter morph appears to be somewhat diachronous (Spiegler and Jansen, this volume). At the top of a barren interval with an interpolated paleomagnetic age of $1.5 \mathrm{Ma}, N$. pachyderma (sin.-encrusted) undergoes a pronounced upward increase in abundance, and this datum is accepted here as an approximation of the Pliocene/Pleistocene boundary, which is generally regarded as $1.6 \mathrm{Ma}$. This boundary is intermediate between the above datum and the last occurrence of $N$. pachyderma (dex.), which is observed only at Section 104-644B-19H-2 (1.7 Ma).

The first occurrence of Thalassiosira oestrupii was accepted as the basal Pliocene marker event in Eldholm, Thiede, Taylor, et al. (1987b), but this termination has been elevated even higher (Sections $104-642 \mathrm{C}-11 \mathrm{H}-5$ to $-642 \mathrm{C}-11 \mathrm{H}-2$ ) by Ciesielski and Case (this volume) to a position now regarded as Chron C3N3/ C3N4 (Bleil, this volume). Consequently, this event probably has an age of $4.6 \mathrm{Ma}$ rather than the $5.35 \mathrm{Ma}$ age indicated by Ciesielski and Case (this volume). The last occurrence of Liriospyris cricus is here recognized as the Miocene/Pliocene marker event, as proposed by Goll and $\mathrm{Bj}$ ørklund (this volume).

In Eldholm, Thiede, Taylor, et al. (1987b), the base of the upper Miocene series was inferred to be unconformable, but morphs regarded as representing early evolutionary stages of Neogloboquadrina acostaensis have been found by Spiegler and Jansen (this volume) at lower depths in Holes 642B and 642C, suggesting that these sediments must have an age of approximately 10.2 Ma (just above a $3.2 \mathrm{~m} . \mathrm{y}$. hiatus). Therefore, the base of the upper Miocene is lowered $28 \mathrm{~m}$ at Site 642 and elevated $7 \mathrm{~m}$ at Site 643. Recently, N. acostaensis has been found in sediments as old as $11 \mathrm{Ma}$ from the Kerguelen Plateau (ODP Leg 120; W. A. Berggren, personal communication). If confirmed, this finding degrades the value of $N$. acostaensis as a biostratigraphic marker in high latitudes and may require a reevaluation of Leg 104 biostratigraphy.

Recognition of the lower Miocene/middle Miocene boundary continues to be problematical. In Eldholm, Thiede, Taylor, et al. (1987b), this boundary was regarded as coincident with the first occurrence of Denticulopsis lauta, despite discussion of the absence of the lower portion of its biostratigraphic range at Site 643. Ciesielski and Case (this volume) lower this event $13 \mathrm{~m}$ in Hole $642 \mathrm{C}$, but its exact position is probably uncertain as a result of coarse sample spacing density in this highly condensed portion of the succession. In the absence of appropriate reference sections with which to compare Leg 104 sediments, Hole $643 \mathrm{~A}$ is interpreted as being characterized by continuous deposition across this subseries boundary, and the first occurrence of Ceratocyrtis manumi is arbitrarily selected without supporting evidence as the only acceptable event marker. Consequently, the lower Miocene/middle Miocene boundary is $13.1 \mathrm{~m}$ deeper in Hole $642 \mathrm{~B}$ and $24.0 \mathrm{~m}$ deeper in Hole $643 \mathrm{~A}$ than indicated in Eldholm, Thiede, Taylor, et al. (1987b). In this synthesis, Hole $642 \mathrm{C}$ is not regarded as having penetrated lower Miocene sediments.

The criterion selected for the Oligocene/Miocene boundary remains unchanged, despite the very limited occurrence of Discolithina enormis in Leg 104 sediments. The stratigraphic position of this series boundary in Hole 643A is supported on the basis of palynological biostratigraphy (Manum et al., this volume).

In Eldholm, Thiede, Taylor, et al. (1987b), the last occurrences of Areosphaeridum multicornuta ( $=A$. pectiniforme of Manum et al., this volume) and Cordosphaeridium funiculatum (= Spiniferites sp. 1) were selected as criteria for the Eocene/ Oligocene boundary. Although Spiniferites sp. is no longer regarded as diagnostic for this contact, the former species has a sharp termination in the interval between Sections 104-643A$50 \mathrm{X}-1$ and $-643 \mathrm{~A}-51 \mathrm{X}-1$, and this level is regarded by Manum et al. (this volume) as marking the top of the youngest Eocene sediments in Hole 643A. This series boundary position has been independently interpreted by Kaminski (1988), who found Eocene agglutinated foraminifer assemblages at least as high as Core 104-643A-47X and perhaps higher. Clearly, the presently available data are not adequate to resolve this controversy, and as a compromise, the Eocene/Oligocene boundary is arbitrarily placed at the base of Areosphaeridum actinocoronatum Zone (dinoflagellates), which is located at the approximate midpoint of the Spirosigmoilinella Assemblage (agglutinated benthic foraminifers) of Kaminski (1988). This assemblage has been reliably dated at Site 647 in the Labrador Sea, where it spans the middle Eocene/late Eocene boundary.

The last occurrences of the dinocysts Rottnestia borussica and Eatonia ursulae were chosen as markers for the middle Eocene/upper Eocene boundary in Eldholm, Thiede, Taylor, et al. (1987b), but occurrences of these species at Site 643 are restricted to a single isolated sample in the basal pyroclastic-rich bed overlying basalt breccia. Because of the possible facies association of these occurrences and the recognition of lower and middle Eocene sediments in the overlying succession, this subseries boundary in Hole $643 \mathrm{~A}$ is placed at a $12 \mathrm{Ma}$ hiatus. As a result of the previously discussed compromise, the Chiropteridium lobospinosum Zone is regarded as representing the only upper Eocene sediments at Site 643.

In the absence of other criteria, the first occurrence of the Glomospira Assemblage (agglutinated foraminifers) is accepted as the marker event for the lower Eocene/middle Eocene boundary. Kaminski (1988) reports the characteristic occurrence of this assemblage in the uppermost lower Eocene of the Alpine flysch basin of southern Europe, and it also spans the lower Eocene/middle Eocene boundary at Site 647 in the Labrador Sea. Kaminski notes numerous first or single occurrences at this level in Hole 643A, including: Recurvoides spp., Saccammina complanata, Reophax subnodulosus, Glomospira charoides, G. irregularis, Hormosina ovuloides, Buzasina sp., Trochamminoides, Karreriella conversa, and Cystammina sp. These typically deepwater taxa may indicate subsidence at Site 643 following early 
Table 1. Comparison of criteria employed to recognize series/subseries boundaries in Eldholm, Thiede, Taylor, et al. (1987b) and in this paper.

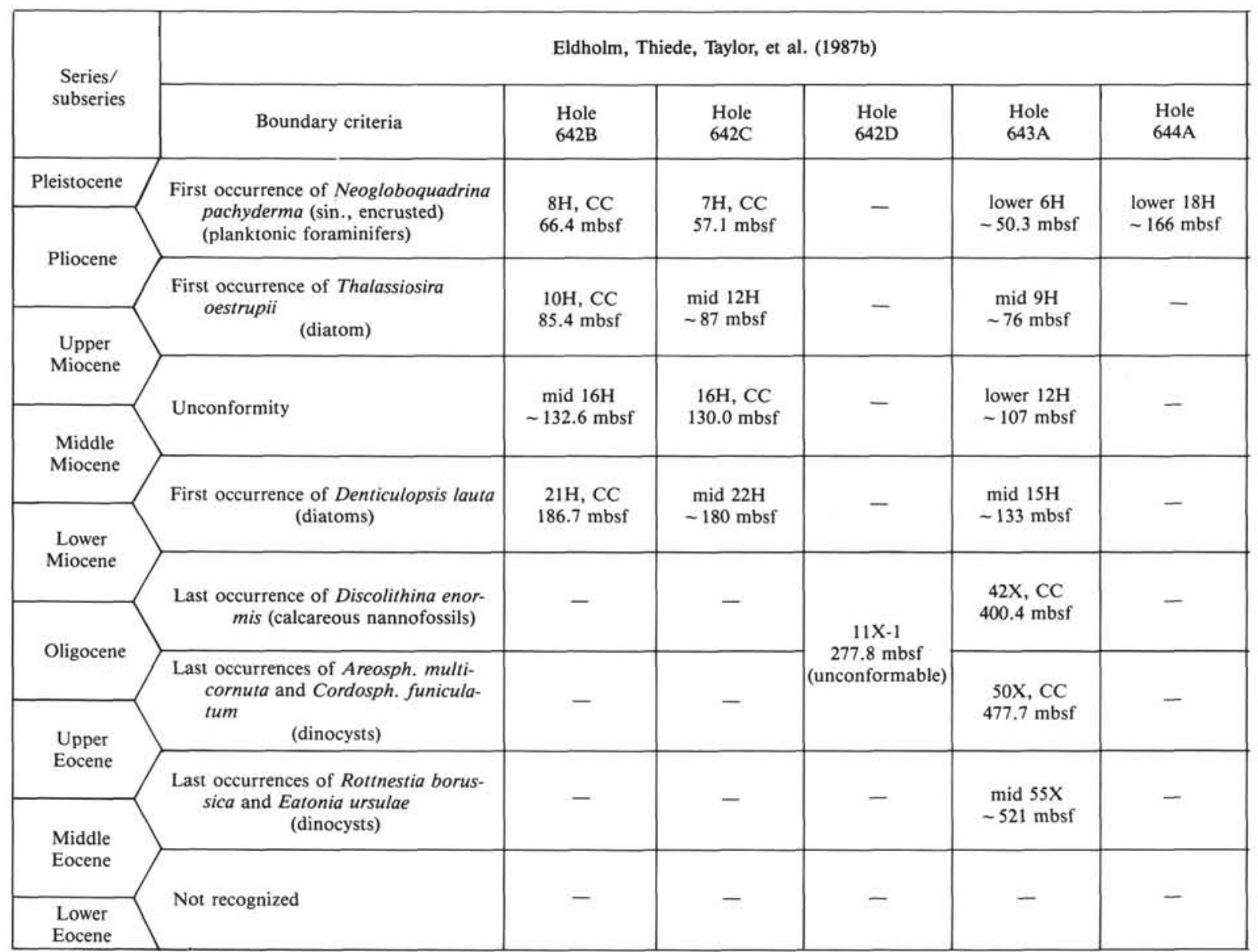

Eocene initiation of seafloor spreading, an inference supported by the high dinocyst relative frequencies reported for this interval by Manum et al. (this volume). Recognition of the Glomospira Assemblage as the basal middle Eocene series boundary results in reasonably good correlations to the foraminifer stratigraphy of the North and Labrador seas, but the notorious facies dependence of benthic foraminifers degrades confidence in this boundary criteria, which may require future emendation.

\section{PALEOMAGNETIC STRATIGRAPHY AND SEDIMENTATION RATES}

The efficacy of coordinated paleomagnetic and biostratigraphic analyses in improving the accuracy of age assignments and correlations is well established. Leg 104 paleomagnetic stratigraphy (Bleil, this volume) serves this function only for sediments younger than $8.8 \mathrm{Ma}$ (Chron $\mathrm{C} 4 \mathrm{~A}$ ) in Hole $643 \mathrm{~A}$ and younger than $5.9 \mathrm{Ma}$ (Chron $\mathrm{C} 3 \mathrm{~A})$ at Site 642 . Below these intervals at both sites, the polarity records do not lend themselves to simple interpretation. Because the paleomagnetic analyses were finished before this biostratigraphic synthesis was completed, it was not possible to thoroughly coordinate the results, and there are discrepancies in chron interpretation between Bleil (this volume) and those of this chapter that require brief explanation. The polarity records and chron assignments of Bleil (this volume) for Holes 642B, 642C, 642D, 643A, and 644A are reproduced in Figures 2-6 (this chapter). Asterisks in the chron columns of these figures indicate a mismatch between the interpretations of Bleil and those of this chapter as represented in
Figure 9 (backpocket). Similarly, there are inconsistencies between the sedimentation rate curves for Sites 642 and 643 of Bleil (this volume, Fig. 14) and the burial history curves of this chapter (Fig. 9).

Below 180 mbsf at Site 642 (Chron C3A), there is a $60 \mathrm{~m}$ interval in which sediments exhibit predominantly positive polarities that can be only partially explained by the long episodes of normal ambient field polarity when these sediments accumulated, and their ages are determinable only on biostratigraphic grounds. At depths of 177 and 179 mbsf in Holes 642B and $642 \mathrm{C}$, respectively, the polarity records appear to improve, and they have been assigned to chrons by Bleil (this volume). Biostratigraphic evidence (based particularly on radiolarians) indicates that the polarity reversal in these lower intervals are not correlative between Holes 642B and 642C, and it is here concluded that chrons cannot be reliably assigned to these possibly spurious records. This condition is particularly obvious by comparison of the polarity reversals in Cores 104-642B-21H to -642B$22 \mathrm{H}$ and Cores $104-642 \mathrm{C}-22 \mathrm{H}$ to $-642 \mathrm{C}-23 \mathrm{H}$. Consequently, polarity changes in this lower interval of Site 642 sediments are not correlative with either the polarity reversals of Hole 643A or the geomagnetic polarity time scale (GPTS)(Bleil, this volume). A sedimentation rate of $26.3 \mathrm{~m} / \mathrm{m}$.y. has been used for the interval from Sections 104-642B-19H-3 to -642B-23H-3, and coeval sediments in Holes $642 \mathrm{C}$ and 642D have been correlated to Hole 642B biostratigraphically. Older Neogene sediments in Holes 642B and 642D have been correlated biostratigraphically to Hole $643 \mathrm{~A}$ without regard to the polarity record of the latter hole or 
Table 1 (continued).

\begin{tabular}{|c|c|c|c|c|c|}
\hline \multicolumn{6}{|c|}{ This Volume } \\
\hline Boundary criteria & $\begin{array}{l}\text { Hole } \\
642 \mathrm{~B}\end{array}$ & $\begin{array}{l}\text { Hole } \\
642 \mathrm{C}\end{array}$ & $\begin{array}{l}\text { Hole } \\
642 \mathrm{D}\end{array}$ & $\begin{array}{l}\text { Hole } \\
643 \mathrm{~A}\end{array}$ & $\begin{array}{l}\text { Hole } \\
644 \mathrm{~A}\end{array}$ \\
\hline $\begin{array}{l}\text { First abundant occurrence of Neoglo- } \\
\text { boquadrina pachyderma } \\
\text { (sin., encrusted) } \\
\text { (planktonic foraminifers) }\end{array}$ & $\begin{array}{c}7 \mathrm{H}-2 \\
50.1 \mathrm{mbsf}\end{array}$ & $\begin{array}{c}6 \mathrm{H}, \mathrm{CC} \\
50.5 \mathrm{mbsf}\end{array}$ & - & $\begin{array}{c}6 \mathrm{H}-2 \\
45.2 \mathrm{mbsf}\end{array}$ & $\begin{array}{c}18 \mathrm{H}-7 \\
168.3 \mathrm{mbsf}\end{array}$ \\
\hline $\begin{array}{l}\text { Last occurrence of Liriospyris cricus } \\
\text { (radiolarians) }\end{array}$ & $\begin{array}{c}11 \mathrm{H}-7 \\
94.7 \mathrm{mbsf}\end{array}$ & $\begin{array}{c}13 \mathrm{H}-1 \\
92.7 \mathrm{mbsf}\end{array}$ & - & $\begin{array}{c}7 \mathrm{H}, \mathrm{CC} \\
62.3 \mathrm{mbsf} \\
\text { (unconformable) }\end{array}$ & - \\
\hline $\begin{array}{l}\text { First occurrence of Neogloboquadrina } \\
\text { acostaensis } \\
\quad \text { (planktonic foraminifers) }\end{array}$ & $\begin{array}{c}19 \mathrm{H}-2 \\
160.3 \mathrm{mbsf}\end{array}$ & $\begin{array}{c}19 \mathrm{H}-6 \\
158.0 \mathrm{mbsf}\end{array}$ & - & $\begin{array}{c}11 \mathrm{H}, \mathrm{CC} \\
100.3 \mathrm{mbsf} \\
\text { (unconformable) }\end{array}$ & - \\
\hline $\begin{array}{l}\text { First occurrence of Ceratocyrtis } \\
\qquad \text { manumi } \\
\text { (radiolarians) }\end{array}$ & $\begin{array}{c}23 \mathrm{H}-3 \\
199.8 \mathrm{mbsf} \\
\text { (unconformable) }\end{array}$ & - & - & $\begin{array}{c}17 X, C C \\
148.5-157.3 \\
\text { mbsf }\end{array}$ & - \\
\hline $\begin{array}{l}\text { Last occurrence of Discolithina enor- } \\
\text { mis } \\
\quad \text { (calcareous nannofossils) }\end{array}$ & - & - & \multirow{3}{*}{$\begin{array}{c}11 X-1 \\
277.8 \text { mbsf } \\
\text { (unconformable) }\end{array}$} & $\begin{array}{c}42 \mathrm{X}, \mathrm{CC} \\
400.4 \mathrm{mbsf}\end{array}$ & - \\
\hline $\begin{array}{l}\text { First occurrence of Areosph. actino- } \\
\text { coronatum } \\
\text { (dinocysts) }\end{array}$ & - & - & & $\begin{array}{c}48 X-5 \\
455.6 \text { mbsf }\end{array}$ & - \\
\hline Unconformity & - & - & & $\begin{array}{c}49 \mathrm{X}, \mathrm{CC} \\
468.1 \mathrm{mbsf}\end{array}$ & - \\
\hline $\begin{array}{l}\text { First occurrence of Glomospira As- } \\
\text { semblage (agglutinated benthic } \\
\text { forams) }\end{array}$ & - & - & - & $\begin{array}{l}54 X-5 \\
513.4 \mathrm{mbsf}\end{array}$ & - \\
\hline
\end{tabular}

the GMTS. The only exception is the oldest Site 642 Neogene sequence (Sections 104-642D-8X-3 to -642D-11X-1), which has been correlated to Chrons C5-C5A.

Similar difficulties have been experienced with the succession in Hole 643A below 114 mbsf (Core 104-643A-13H). Despite considerable effort, a reliable match has not been found between the polarity records of these sediments and the GPTS that is consistent with the existing biostratigraphic control. Evidence of slump disturbance, which is obvious sedimentologically and possibly inferred from seismic records, has already been discussed. Additional biostratigraphic studies are needed to improve confidence in age assignments of the sequences and hiatuses in this succession. Because of the preliminary state of our present knowledge regarding the chronostratigraphy of these sediments, the expedient of a constant sedimentation rate $(39.7 \mathrm{~m} /$ m.y.) has been applied to the succession between Cores 104$643 \mathrm{~A}-12 \mathrm{H}$ and $-643 \mathrm{~A}-29 \mathrm{X}$. The top of the succession has been correlated biostratigraphically from Cores 104-642B-20H to $-642 \mathrm{~B}-22 \mathrm{H}$. The polarity reversal in Core 104-643A-28X is provisionally correlated with the top of Chron C5E as a working hypothesis to fix the base of the succession, and core bottom ages shown in Figure 9 (backpocket) are interpolated on this basis.

\section{SITE SUMMARIES}

Six biozonations or assemblage schemes are proposed in this volume for: Bolboforma, calcareous nannofossils, benthic and planktonic foraminifers, ebridians-actiniscidians, and radiolarians. Additionally, two biozonations are proposed for the silico- flagellates. The dinoflagellate investigations by Mudie (this volume) and Manum et al. (this volume) are here treated as a single biozonation, although there are minor inconsistencies in the interval of overlap, as has been described in the Microfossil Studies by Group section. Diagrams comparing the various biozonations proposed in this volume for Holes 642B, 642C, 642D, $643 \mathrm{~A}$, and $644 \mathrm{~A}$ are presented in Figures 2-6. These data are also included in Table 2 . The biostratigraphy of Hole $644 \mathrm{~B}$ has been treated only by Mudie (this volume), who records dinocyst biostratigraphy essentially identical to that of the upper part of Hole 644A. A diagram is not provided for Hole 644B, which will not be discussed further in this synthesis. Regrettably, the thoroughness with which the five holes have been investigated in the contributions of this volume varies significantly. Where they occur, Bolboforma, benthic and planktonic foraminifers, and radiolarians have been treated uniformly in all these holes by the same investigators. One or more holes have been ignored for some fossil groups, however, and two groups of specialists with differing taxonomic perspectives have treated the dinoflagellates and silicoflagellates.

\section{Site 642}

Lat.: $67^{\circ} 13.5^{\prime} \mathrm{N}$

Long.: $2^{\circ} 55.7^{\prime} \mathrm{E}$

Water Depth: $1286 \mathrm{~m}$

\section{Hole 642B}

Diatoms, ebridians and actiniscidians, and silicoflagellates have not been studied in Hole 642B for this volume, but benthic 


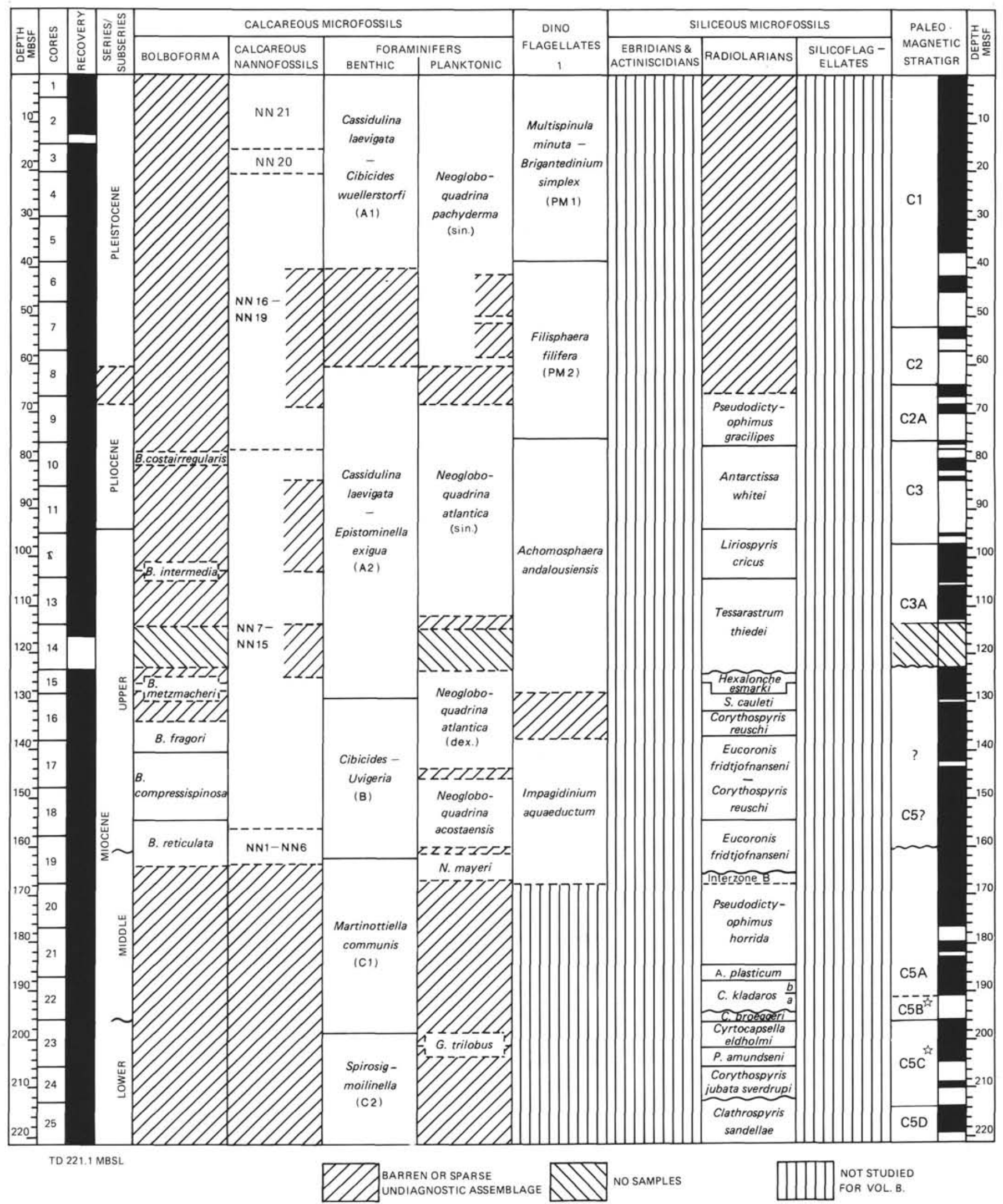

Figure 2. Comparison of biozonations presented in this volume for Hole 642B. 1, Mudie (this volume); TD, total depth. The paleomagnetic stratigraphy follows Bleil (this volume). Stars in chron column indicate that the age attributed to the specific chron by Berggren et al. (1985) is not consistent with the age assigned to these sediments in Figure 9. 
Table 2. Distribution of biozonations in Leg 104 holes. The data have been extracted from individual papers identified in the sections on Microfossil Studies by Group and Site Reports. 1, Ciesielski, Hasson, and Turner (this volume); 2, Locker, and Martini (this volume).

\begin{tabular}{|c|c|c|c|c|c|c|}
\hline & Zone/Assemblage & Hole $642 \mathrm{~B}(\mathrm{~cm})$ & Hole $642 \mathrm{C}(\mathrm{cm})$ & Hole $642 \mathrm{D}(\mathrm{cm})$ & Hole $643 \mathrm{~A}(\mathrm{~cm})$ & Hole $644 \mathrm{~A}(\mathrm{~cm})$ \\
\hline \multirow{7}{*}{ 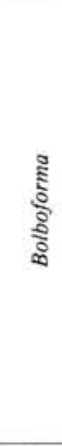 } & $\begin{array}{l}\text { Bolboforma costairregu- } \\
\text { laris }\end{array}$ & $\begin{array}{l}10 \mathrm{H}-3(50) \text { to } 10 \mathrm{H}-4 \text { ( } 58) \\
79.4-80.8 \mathrm{mbsf}\end{array}$ & $\begin{array}{l}11 \mathrm{H}-4(114) \text { to } 11 \mathrm{H}-6(114) \\
78.5-81.4 \mathrm{mbsf}\end{array}$ & - & & - \\
\hline & Bolboforma intermedia & $\begin{array}{r}12 \mathrm{H}-6(61) \\
103.0 \mathrm{mbsf}\end{array}$ & - & - & & - \\
\hline & Bolboforma metzmacheri & $\begin{array}{c}15 \mathrm{H}-2(113) \text { to } 15 \mathrm{H}-3(113) \\
126.2-127.7 \mathrm{mbsf}\end{array}$ & $\begin{array}{l}16 \mathrm{H}-3(102) \text { to } 16 \mathrm{H}-4(102) \\
124.5-126.2 \mathrm{mbsf}\end{array}$ & - & & - \\
\hline & Bolboforma laevis & - & - & - & $\begin{array}{c}10 \mathrm{H}-4(40) \text { to } 11 \mathrm{H}-1(40) \\
86.2-91.2 \mathrm{mbsf}\end{array}$ & - \\
\hline & Bolboforma fragori & $\begin{array}{c}16 \mathrm{H}-6(116) \text { to } 17 \mathrm{H}-2(114) \\
135.3-140.7 \mathrm{mbsf}\end{array}$ & $\begin{array}{c}17 \mathrm{H}-2(105) \text { to } 17 \mathrm{H}-6(81) \\
132.6-138.3 \mathrm{mbsf}\end{array}$ & - & $\begin{array}{c}11 \mathrm{H}-2(40) \text { to } 11 \mathrm{H}-6(40) \\
92.7-98.7 \mathrm{mbsf}\end{array}$ & - \\
\hline & $\begin{array}{l}\text { Bolboforma compressis- } \\
\text { pinosa }\end{array}$ & $\begin{array}{c}17 \mathrm{H}-3(114) \text { to } 18 \mathrm{H}-4(114) \\
142.7-153.5 \mathrm{mbsf}\end{array}$ & $\begin{array}{c}17 \mathrm{H}, \mathrm{CC} \text { to } 19 \mathrm{H}-2(88) \\
139.2-151.2 \mathrm{mbsf}\end{array}$ & - & $\begin{array}{l}11 \mathrm{H}-6(40) \text { to } 11 \mathrm{H}-7(16) \\
98.7-99.9 \mathrm{mbsf}\end{array}$ & - \\
\hline & Bolboforma reticulata & $\begin{array}{l}18 \mathrm{H}-5(114) \text { to } 19 \mathrm{H}-4(105) \\
155.0-163.3 \mathrm{mbsf}\end{array}$ & $\begin{array}{l}19 \mathrm{H}-3(77) \text { to } 20 \mathrm{H}-1(82) \\
152.6-159.3 \mathrm{mbsf}\end{array}$ & - & - & - \\
\hline \multirow{6}{*}{ 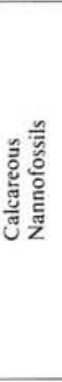 } & $\mathrm{NN} 21$ & $\begin{array}{c}1 \mathrm{H}-1(30) \text { to } 2 \mathrm{H}-6( \\
0.3-13.2 \mathrm{mbsf}\end{array}$ & $\begin{array}{l}\text { ? to } 3 \mathrm{H}-1(16) \\
-14 \mathrm{mbsf}\end{array}$ & - & $\begin{array}{l}1 \mathrm{H}-1(50) \text { to } 1 \mathrm{H}-2(50) \\
0.5-2.0 \mathrm{mbsf}\end{array}$ & $\begin{array}{c}\text { 1H-1 (50) to } 4 \mathrm{H}-1 \text { ( } 50) \\
0.5-26.2 \mathrm{mbsf}\end{array}$ \\
\hline & NN20 & $\begin{array}{l}3 \mathrm{H}-2(87) \text { to } 3 \mathrm{H}-4(18) \\
15.7-19.0 \mathrm{mbsf}\end{array}$ & $\begin{array}{l}\text { ? to } 3 \mathrm{H}-5(6) \\
-20 \mathrm{mbsf}\end{array}$ & - & $\begin{array}{c}1 \mathrm{H}-3(50) \text { to } 2 \mathrm{H}-4(125) \\
3.5-11.0 \mathrm{mbsf}\end{array}$ & $\begin{array}{l}4 \mathrm{H}-2(50) \text { to } 6 \mathrm{H}-3(125) \\
27.7-49.0 \mathrm{mbsf}\end{array}$ \\
\hline & NN16-NN19 & $\begin{array}{c}4 \mathrm{H}-1(107) \text { to } 10 \mathrm{H}-1(6) \\
21.8-76.0 \mathrm{mbsf}\end{array}$ & $\begin{array}{l}\text { ? to } 11 \mathrm{H}, \mathrm{CC} \\
-82 \mathrm{mbsf}\end{array}$ & - & $\begin{array}{c}2 \mathrm{H}-5 \text { (125) to } 9 \mathrm{H}-1 \text { (125) } \\
12.6-73.0 \mathrm{mbsf}\end{array}$ & $\begin{array}{c}6 \mathrm{H}-5(50) \text { to } 34 \mathrm{H}-6(125) \\
51.2-254.8 \mathrm{mbsf}\end{array}$ \\
\hline & NN7-NNI5 & $\begin{array}{c}10 \mathrm{H}-2(96) \text { to } 18 \mathrm{H}-5(102) \\
78.4-153.9 \mathrm{mbsf}\end{array}$ & $\begin{array}{l}\text { ? to } 19 \mathrm{H}, \mathrm{CC} \\
\text { - } 158 \mathrm{mbsf}\end{array}$ & - & $\begin{array}{c}9 \mathrm{H}-2(125) \text { to } 11 \mathrm{H}-6(50) \\
74.6-98.8 \mathrm{mbsf}\end{array}$ & - \\
\hline & NN1-NN6 & $\begin{array}{c}18 \mathrm{H}-6(102) \text { to } 19 \mathrm{H}-4(8) \\
156.3-162.3 \mathrm{mbsf}\end{array}$ & - & - & $\begin{array}{l}42 X, C C(5-6) \\
400.4 \mathrm{mbsf}\end{array}$ & - \\
\hline & NP25 & - & - & - & $\begin{array}{c}43 X, C C \\
400.9 \mathrm{mbsf}\end{array}$ & - \\
\hline \multirow{7}{*}{ 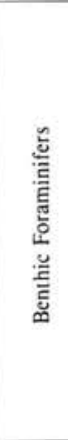 } & \multirow[b]{2}{*}{ A } & $\begin{array}{c}1 \mathrm{H}-1(74-78) \text { to } 6 \mathrm{H}-1(44-48) \\
0.7-39.4 \mathrm{mbsf}\end{array}$ & $\begin{array}{c}1 \mathrm{H}-1 \text { ( } 82-86) \text { to } 4 \mathrm{H}-6(28-32) \\
0.8-30.9 \mathrm{mbsf}\end{array}$ & - & \multirow{2}{*}{$\begin{array}{l}\text { 1H }(4-8) \text { to } 8 \mathrm{H}-4(74-78) \\
0-69.0 \mathrm{mbsf}\end{array}$} & $\begin{array}{c}1 \mathrm{H}-1 \text { ( } 75-79) \text { to } 24 \mathrm{H}-4(75-79) \\
0.8-206.0 \mathrm{mbsf}\end{array}$ \\
\hline & & $\begin{array}{c}9 \mathrm{H}-1(52-56) \text { to } 16 \mathrm{H}-1(69-73) \\
67.0-129.0 \mathrm{mbsf}\end{array}$ & $\begin{array}{c}8 \mathrm{H}, \mathrm{CC} \text { to } 16 \mathrm{H}-2 \text { (74-78) } \\
60.9-122.9 \mathrm{mbsf}\end{array}$ & - & & $\begin{array}{c}32 \mathrm{H}-1(75-79) \text { to } 34 \mathrm{H}, \mathrm{CC} \\
239.0-252.8 \mathrm{mbsf}\end{array}$ \\
\hline & B & $\begin{array}{c}16 \mathrm{H}-6(69-73) \text { to } 19 \mathrm{H}-4(72-76) \\
129-163.0 \mathrm{mbsf} \\
\end{array}$ & $\begin{array}{c}16 \mathrm{H}-4(74-78) \text { to } 19 \mathrm{H}, \mathrm{CC} \\
125.7-158.5 \mathrm{mbsf}\end{array}$ & - & $\begin{array}{c}8 \mathrm{H}-5(74-78) \text { to } 11 \mathrm{H}-3(75-79) \\
70.5-96.1 \mathrm{mbsf} \\
\end{array}$ & - \\
\hline & $\mathrm{Cl}$ & $\begin{array}{c}19 \mathrm{H}-5(72.76) \text { to } 23 \mathrm{H}-1(66-69) \\
163.0-197.0 \mathrm{mbsf}\end{array}$ & $\begin{array}{c}20 \mathrm{H}-2(72-75) \text { to } 23 \mathrm{H}, \mathrm{CC} \\
161.2-192.4 \mathrm{mbsf}\end{array}$ & $\begin{array}{c}2 X-1 \text { (73-75) to } 2 X-6(73-75) \\
189.8-198.1 \mathrm{mbsf}\end{array}$ & - & - \\
\hline & $\mathrm{C} 2$ & $\begin{array}{c}23 \mathrm{H}-2(66-69) \text { to } 25 \mathrm{H}, \mathrm{CC} \\
198.2-221.1 \mathrm{mbsf}\end{array}$ & $\begin{array}{c}24 \mathrm{H}-2(78-81) \text { to } 24 \mathrm{H}, \mathrm{CC} \\
194.7-199.6 \mathrm{mbsf} \\
\end{array}$ & $\begin{array}{l}2 \mathrm{X}, \mathrm{CC} \text { to } 10 \mathrm{X}, \mathrm{CC} \\
199.6-276.8 \mathrm{mbsf} \\
\end{array}$ & $\begin{array}{c}11 \mathrm{H}-4(76-80) \text { to } 35 \mathrm{X}, \mathrm{CC} \\
97.6-326.5 \mathrm{mbsf}\end{array}$ & - \\
\hline & D & - & - & & $\begin{array}{c}36 \mathrm{X}-1(80-84) \text { to } 53 \mathrm{X}-3(75-78) \\
333.8-502.3 \mathrm{mbsf}\end{array}$ & - \\
\hline & $\mathrm{E}$ & - & - & & $\begin{array}{c}53 \mathrm{X}-4 \text { (75-78) to } 57 \mathrm{X}-6 \text { (75-78) } \\
503.7-545.4 \mathrm{mbsf}\end{array}$ & - \\
\hline \multirow{5}{*}{ 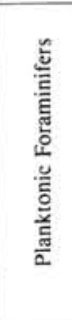 } & $\begin{array}{l}\text { Neogloboquadrina pachy- } \\
\text { derma (sin-enc'd) }\end{array}$ & $\begin{array}{c}1 \mathrm{H}-1(39-41) \text { to } 7 \mathrm{H}-2(130-132) \\
0.4-50.1 \mathrm{mbsf} \\
\end{array}$ & $\begin{array}{c}1 \mathrm{H}-1(04-06) \text { to } 6 \mathrm{H}-2, \mathrm{CC} \\
0-50.5 \mathrm{mbsf}\end{array}$ & - & $\begin{array}{c}1 \mathrm{H}-1(20) \text { to } 6 \mathrm{H}-2(82) \\
0.2-45.2 \mathrm{mbsf}\end{array}$ & $\begin{array}{c}1 \mathrm{H}-1(20-22) \text { to } 18 \mathrm{H}-7(59-61) \\
0.2-168.3 \mathrm{mbsf}\end{array}$ \\
\hline & N. pachyderma (dex.) & - & - & - & - & $\begin{array}{c}19 \mathrm{H}-2(22) \text { to } 19 \mathrm{H}-4(100) \\
169.9-173.7 \mathrm{mbsf}\end{array}$ \\
\hline & $\begin{array}{l}\text { N. atlantica (dex.) } \\
\text { upper }\end{array}$ & - & - & - & - & $\begin{array}{c}20 \mathrm{H}-1(102) \text { to } 26 \mathrm{H}-1(102) \\
178.4-211.5 \mathrm{mbsf}\end{array}$ \\
\hline & N. atlantica $(\sin )$. & $\begin{array}{c}9 \mathrm{H}-2(27-29) \text { to } 13 \mathrm{H}-6(105-107) \\
68.1-112.8 \mathrm{mbsf}\end{array}$ & $\begin{array}{c}9 \mathrm{H}-1(103-105) \text { to } 15 \mathrm{H}-1(112-114) \\
60.8-112.1 \mathrm{mbsf}\end{array}$ & - & $\begin{array}{c}7 \mathrm{H}-1 \text { (125-127) to } 7 \mathrm{H}-5(11-13) \\
54.1-59.4 \mathrm{mbsf}\end{array}$ & \\
\hline & $\begin{array}{l}\text { N. allantica (dex.) } \\
\text { lower }\end{array}$ & $\begin{array}{c}15 \mathrm{H}-1(112-114) \text { to } 17 \mathrm{H}-3(113-115) \\
124.8-143.7 \mathrm{mbsf}\end{array}$ & $\begin{array}{c}16 \mathrm{H}-2(103-105) \text { to } 17 \mathrm{H}-6(80-82) \\
123.0-138.3 \mathrm{mbsf}\end{array}$ & - & $\begin{array}{c}\text { to } 9 \mathrm{H}-1 \text { ( }(39-41) \\
-72.2 \mathrm{mbsf}\end{array}$ & \\
\hline
\end{tabular}




\begin{tabular}{|c|c|c|c|c|c|c|}
\hline & Zone/Assemblage & Hole $642 \mathrm{~B}(\mathrm{~cm})$ & Hole $642 \mathrm{C}(\mathrm{cm})$ & Hole 642D $(\mathrm{cm})$ & Hole $643 \mathrm{~A}(\mathrm{~cm})$ & Hole $644 \mathrm{~A}(\mathrm{~cm})$ \\
\hline \multirow{4}{*}{ 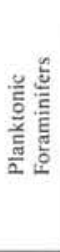 } & N. acostaensis & $\begin{array}{c}17 \mathrm{H}-6(113-115) \text { to } 19 \mathrm{H}-2(104-106) \\
146.7-160.3 \mathrm{mbsf}\end{array}$ & $\begin{array}{c}19 \mathrm{H}-1(56-58) \text { to } 19 \mathrm{H}, \mathrm{CC} \\
149.6-158.0 \mathrm{mbsf}\end{array}$ & - & $\begin{array}{c}11 \mathrm{H}-6 \text { (39-41) to } 11 \mathrm{H}-7 \text { (15-17) } \\
\quad 98.7-100.0 \mathrm{mbsf}\end{array}$ & \\
\hline & N. mayeri & $\begin{array}{c}19 \mathrm{H}-4(71-73) \text { to } 20 \mathrm{H}-1(102-104) \\
162.9-168.4 \mathrm{mbsf}\end{array}$ & $\begin{array}{l}19 \mathrm{H}, \mathrm{CC} \text { to } 20 \mathrm{H}-1(80-82) \\
158.0-159.3 \mathrm{mbsf}\end{array}$ & - & - & - \\
\hline & Globigerinoides trilobus & $\begin{array}{c}23 \mathrm{H}-2(10-12) \\
199.1 \mathrm{mbsf}\end{array}$ & - & - & - & - \\
\hline & $\begin{array}{l}\text { Neogloboquadrina nana/ } \\
\text { N. continuosa }\end{array}$ & - & - & - & $\begin{array}{c}16 \mathrm{H}-3(37-39) \\
141.7 \mathrm{mbsf}\end{array}$ & \\
\hline \multirow{17}{*}{ 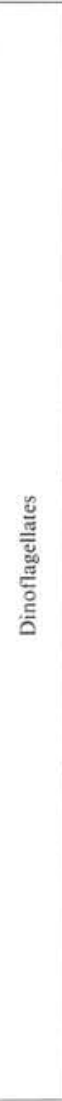 } & $\begin{array}{l}\text { Multispinula minutal } \\
\text { Brigantedinium } \\
\text { simplex }\end{array}$ & $\begin{array}{c}1 \mathrm{H}-1 \text { ( } 42) \text { to } 5 \mathrm{H}, \mathrm{CC} \\
0.4-38.9 \mathrm{mbsf}\end{array}$ & - & - & $\begin{array}{l}1 \mathrm{H}-1 \text { ( ) }) \text { to } 4 \mathrm{H}, \mathrm{CC} \\
-33.8 \mathrm{mbsf}\end{array}$ & $\begin{array}{l}7 \mathrm{H}-1 \text { (18) to } 10 \mathrm{H}-3 \text { ( } 35) \\
54.4-86.0 \mathrm{mbsf}\end{array}$ \\
\hline & Filisphaera filifera & $\begin{array}{c}6 \mathrm{H}-1(42) \text { to } 9 \mathrm{H}, \mathrm{CC} \\
39.3-75.9 \text { mbsf } \\
\end{array}$ & $\begin{array}{c}10 \mathrm{H}-6(43) \text { to } 11 \mathrm{H}-3(42) \\
71.4-76.4 \mathrm{mbsf} \\
\end{array}$ & - & $\begin{array}{c}5 \mathrm{H}, \mathrm{CC} \text { to } 7 \mathrm{H}, \mathrm{CC} \\
43.2-61.0 \mathrm{mbsf}\end{array}$ & $\begin{array}{c}10 \mathrm{H}-3(85) \text { to } 34 \mathrm{H}-6(137) \\
86.5-254.9 \mathrm{mbsf}\end{array}$ \\
\hline & $\begin{array}{l}\text { Achomosphaera andalou- } \\
\text { siensis }\end{array}$ & $\begin{array}{l}10 \mathrm{H}, \mathrm{CC} \text { to } 16 \mathrm{H}, \mathrm{CC} \\
85.4-138.0 \mathrm{mbsf}\end{array}$ & $\begin{array}{c}12 \mathrm{H}-1(78-80) \text { to } 15 \mathrm{H}-1(79-81) \\
83.3-111.8 \mathrm{mbsf}\end{array}$ & - & $\begin{array}{c}8 \mathrm{H}-6(48-50) \text { to } 12 \mathrm{H}-1(31-33) \\
70.3-100.6 \mathrm{mbsf}\end{array}$ & - \\
\hline & $\begin{array}{l}\text { Impagidinium aquaeduc- } \\
\text { tum }\end{array}$ & $\begin{array}{c}17 \mathrm{H}, \mathrm{CC} \text { to } 20 \mathrm{H}, \mathrm{CC} \\
147.7-177.1 \mathrm{mbsf}\end{array}$ & $\begin{array}{c}17 \mathrm{H}-1 \text { (69-72) to } 20 \mathrm{H}-7(67-70) \\
130.7-167.6 \mathrm{mbsf}\end{array}$ & - & $\begin{array}{c}12 \mathrm{H}-4(31-33) \text { to } 12 \mathrm{H}-5(31-33) \\
105.1-106.6 \mathrm{mbsf}\end{array}$ & - \\
\hline & $\begin{array}{l}\text { Labyrinthodinium trunca- } \\
\text { tum }\end{array}$ & - & $\begin{array}{c}21 \mathrm{H}-6(81-84) \text { to } 23 \mathrm{H}-2(81-84) \\
176.3-186.6 \mathrm{mbsf}\end{array}$ & - & $\begin{array}{c}13 \mathrm{H}-6(31-33) \text { to } 14 \mathrm{H}-5(32-34) \\
117.6-125.6 \mathrm{mbsf}\end{array}$ & - \\
\hline & Emslandia spiridoides & - & $\begin{array}{c}24 \mathrm{H}-3(81-84) \\
196.2 \mathrm{mbsf}\end{array}$ & $\begin{array}{l}3 X-2(80-82) \\
201.9 \mathrm{mbsf}\end{array}$ & $\begin{array}{c}15 \mathrm{H} \cdot 6(28-30) \text { to } 20 \mathrm{X}-6(30-32) \\
136.6-184.1 \mathrm{mbsf} \\
\end{array}$ & - \\
\hline & Impagidinium patulum & - & - & $\begin{array}{c}5 \mathrm{X}-6(80-82) \text { to } 12 \mathrm{X}-6(81-84) \\
277.2-294.8 \mathrm{mbsf}\end{array}$ & $\begin{array}{c}22 X-5(30-32) \text { to } 27 X-5(31-33) \\
201.6-250.6 \mathrm{mbsf}\end{array}$ & - \\
\hline & $\begin{array}{l}\text { Evittosphaerula paratabu- } \\
\text { lata }\end{array}$ & - & - & $\begin{array}{l}13 \mathrm{X}-1 \text { (81-84) } \\
297.1 \mathrm{mbsf}\end{array}$ & $\begin{array}{c}28 \mathrm{X}-7(30-32) \text { to } 34 \mathrm{X}-2(30-32) \\
263.4-314.7 \mathrm{mbsf}\end{array}$ & - \\
\hline & Ascostomocystis granosa & - & - & - & $\begin{array}{c}36 \mathrm{X}-5(30-32) \text { to } 42 \mathrm{X}-4(19-21) \\
338.8-295.4 \mathrm{mbsf}\end{array}$ & - \\
\hline & Systematophora sp. 1 & - & - & - & $\begin{array}{c}44 \mathrm{X}-1 \text { (30-32) to } 45 \mathrm{X}-5(29-31) \\
410.5-426.0 \mathrm{mbsf}\end{array}$ & - \\
\hline & Impagidinium sp. 1 & - & - & - & $\begin{array}{l}46 \mathrm{X}-1(82-84) \text { to } 46 \mathrm{X}-5(82-84) \\
430.2-436.2 \mathrm{mbsf}\end{array}$ & - \\
\hline & $\begin{array}{l}\text { Areosphaeridium actino. } \\
\text { corunatum }\end{array}$ & - & - & - & $\begin{array}{c}47 \mathrm{X}-1 \text { ( }(90-92) \text { to } 48 \mathrm{X}-5(90-92) \\
440.0-455.6 \mathrm{mbsf}\end{array}$ & - \\
\hline & $\begin{array}{l}\text { Chiropteridium lobospino- } \\
\text { sum }\end{array}$ & - & - & - & $\begin{array}{c}48 \mathrm{X}-6(90-92) \text { to } 50 \mathrm{X}-1(30-32) \\
457.1-468.4 \mathrm{mbsf}\end{array}$ & - \\
\hline & $\begin{array}{l}\text { Areosphaeridium ar- } \\
\text { cuatum }\end{array}$ & - & - & - & $\begin{array}{c}51 \mathrm{X}-1(30-32) \text { to } 51 \mathrm{X}-4(30-32) \\
478.0-482.5 \mathrm{mbsf} \\
\end{array}$ & - \\
\hline & Deflandrea sp. B & - & - & - & $\begin{array}{c}52 \mathrm{X}-3(28-30) \text { to } 53 \mathrm{X}-3(30-33) \\
490.6-500.3 \mathrm{mbsf}\end{array}$ & - \\
\hline & $\begin{array}{c}\text { Adnatosphaeridium } \\
\text { vittatum }\end{array}$ & - & - & - & $\begin{array}{l}54 \mathrm{X}-1 \text { ( }(30-32) \text { to } 57 \mathrm{X}-5(30-32) \\
507.0-541.9 \mathrm{mbsf}\end{array}$ & - \\
\hline & Rottnestia borussica & - & - & - & $\begin{array}{c}60 X-2(31-33) \\
556.7 \mathrm{mbsf}\end{array}$ & - \\
\hline \multirow{2}{*}{ 厗 } & Actiniscus pentasterias & - & - & - & - & $\begin{array}{c}2 \mathrm{H}-2(74-75) \text { to } 17 \mathrm{H}-2(66-67) \\
84.9-151.4 \mathrm{mbsf}\end{array}$ \\
\hline & Ammodochium serotinum & - & - & - & - & $\begin{array}{c}21 \mathrm{H}-1 \text { (66-67) to } 23 \mathrm{H}-2 \text { (55-56) } \\
185.5-196.2 \mathrm{mbsf}\end{array}$ \\
\hline
\end{tabular}


Table 2 (continued).

\begin{tabular}{|c|c|c|c|c|c|c|}
\hline & Zone/Assemblage & Hole $642 \mathrm{~B}(\mathrm{~cm})$ & Hole $642 \mathrm{C}(\mathrm{cm})$ & Hole 642D $(\mathrm{cm})$ & Hole $643 \mathrm{~A}(\mathrm{~cm})$ & Hole $644 \mathrm{~A}(\mathrm{~cm})$ \\
\hline \multirow{7}{*}{ 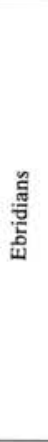 } & Ebriopsis cornuta & - & $\begin{array}{c}9 \mathrm{H}-1(64-65) \text { to } 12 \mathrm{H}-6(65-66) \\
61.3-90.6 \mathrm{mbsf}\end{array}$ & - & - & $\begin{array}{c}30 \mathrm{H}-2(56-57) \text { to } 34 \mathrm{H}-5(66-67) \\
228.2-252.7 \mathrm{mbsf}\end{array}$ \\
\hline & Parathranium clathratum & - & $\begin{array}{c}13 \mathrm{H}-1 \mathrm{1}(66.67) \text { to } 17 \mathrm{H}-4(15-16) \\
92.7-134.6 \mathrm{mbsf}\end{array}$ & - & - & - \\
\hline & Hermesinella schulzii & - & $\begin{array}{c}17 \mathrm{H}-5(50-51) \text { to } 21 \mathrm{H}-5(60-61) \\
136.5-174.6 \mathrm{mbsf}\end{array}$ & - & - & - \\
\hline & Spongebria miocenica & - & $\begin{array}{c}21 \mathrm{H}-6(60-61) \text { to } 24 \mathrm{H}-5(70-72) \\
176.1-199.1 \mathrm{mbsf}\end{array}$ & - & - & - \\
\hline & Hermesinella adriaticum & - & - & $\begin{array}{c}3 \mathrm{X}-1 \text { (160-61) to 6X-4 (66-67) } \\
200.2-233.7 \mathrm{mbsf}\end{array}$ & - & - \\
\hline & Foliactiniscus folia & - & - & $\begin{array}{c}6 \mathrm{X}-5(66-67) \text { to } 10 \mathrm{X}-2(70-71) \\
235.2-269.3 \mathrm{mbsf}\end{array}$ & - & - \\
\hline & Foliactiniscus atlanticus & - & - & $\begin{array}{c}10 \mathrm{X}-3(70-71) \text { to } 11 X-1 \text { (155-56) } \\
270.8-277.4 \mathrm{mbsf}\end{array}$ & - & - \\
\hline \multirow{16}{*}{ 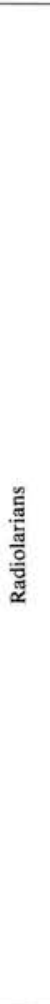 } & $\begin{array}{l}\text { Cycladophora davisiana } \\
\text { davisiana }\end{array}$ & - & - & - & - & $\begin{array}{c}\text { Top to } 30 \mathrm{H}-3 \text { (25-27) } \\
0-229.4 \mathrm{mbsf}\end{array}$ \\
\hline & Spongaster?tetras & - & - & - & - & $\begin{array}{c}31 \mathrm{H}-3(25-27) \text { to } 34 \mathrm{H}, \mathrm{CC} \\
236.9-252.8 \mathrm{mbsf}\end{array}$ \\
\hline & $\begin{array}{l}\text { Pseudodictyophimus } \\
\text { gracilipes tetracanthus }\end{array}$ & $\begin{array}{c}9 \mathrm{H}-1(75-77) \text { to } 10 \mathrm{H}-1 \text { ( }(75-77) \\
67.2-76.7 \mathrm{mbsf}\end{array}$ & $\begin{array}{l}9 \mathrm{H}, \mathrm{CC} \text { to } 11 \mathrm{H}-3(70-72) \\
63.5-76.7 \mathrm{mbsf}\end{array}$ & - & - & - \\
\hline & Antarctissa whitei & $\begin{array}{c}10 \mathrm{H}-2(25-27) \text { to } 11 \mathrm{H}-6(25-27) \\
77.7-93.2 \mathrm{mbsf}\end{array}$ & $\begin{array}{c}11 \mathrm{H}-4(70-72) \text { to } 12 \mathrm{H}, \mathrm{CC} \\
78.2-92.0 \mathrm{mbsf}\end{array}$ & - & - & - \\
\hline & Liriospyris cricus & $\begin{array}{c}11 \mathrm{H}-7(25-27) \text { to } 12 \mathrm{H}, \mathrm{CC} \\
94.7-104.2 \mathrm{mbsf}\end{array}$ & $\begin{array}{c}13 \mathrm{H}-1 \text { ( } 70-72) \text { to } 14 \mathrm{H}-2(70-72) \\
92.7-103.7 \mathrm{mbsf}\end{array}$ & - & - & - \\
\hline & Tessarastrum thiedei & $\begin{array}{c}13 \mathrm{H}-1(24-26) \text { to } 15 \mathrm{H}-1(27-29) \\
104.4-123.8 \mathrm{mbsf}\end{array}$ & $\begin{array}{c}14 \mathrm{H}-3(70-72) \text { to } 15 \mathrm{H}-6(25-27) \\
105.2-118.8 \mathrm{mbsf}\end{array}$ & - & $\begin{array}{c}8 \mathrm{H}-1(103-105) \text { to } 8 \mathrm{H}-5(103-105) \\
? 67.0-69.3 \mathrm{mbsf} ?\end{array}$ & - \\
\hline & Larcospira bulbosa & - & $\begin{array}{c}15 \mathrm{H}-7(25-27) \text { to } 15 \mathrm{H}, \mathrm{CC} \\
120.3-120.5 \mathrm{mbsf}\end{array}$ & - & - & - \\
\hline & Hexalonche esmarki & $\begin{array}{c}15 \mathrm{H}-2(27-29) \\
125.3 \mathrm{mbsf}\end{array}$ & $\begin{array}{c}16 \mathrm{H}-1(25-27) \text { to } 16 \mathrm{H}-3(25-27) \\
120.8-123.8 \mathrm{mbsf}\end{array}$ & - & $\begin{array}{c}8 \mathrm{H}-6(103-105) \text { to } 9 \mathrm{H}, \mathrm{CC} \\
70.8-81.3 \mathrm{mbsf}\end{array}$ & - \\
\hline & Spongurus cauleti & $\begin{array}{c}15 \mathrm{H}-3(27-29) \text { to } 16 \mathrm{H}-2(31-33) \\
126.8-129.9 \mathrm{mbsf}\end{array}$ & $\begin{array}{c}16 \mathrm{H}-4(25-27) \text { to } 16 \mathrm{H}-5(25-27) \\
125.3-126.8 \mathrm{mbsf}\end{array}$ & - & $\begin{array}{c}10 \mathrm{H}-1 \text { (105-107) to } 10 \mathrm{H}-5(105-107) \\
82.4-88.4 \mathrm{mbsf}\end{array}$ & - \\
\hline & Corythospyris reuschi & $\begin{array}{c}16 \mathrm{H}-3(31-33) \text { to } 16 \mathrm{H}-7 \text { (31-33) } \\
131.4-137.4 \mathrm{mbsf}\end{array}$ & $\begin{array}{c}16 \mathrm{H}-6(25-27) \text { to } 17 \mathrm{H}-2(25-27) \\
128.3-131.8 \mathrm{mbsf}\end{array}$ & - & $\begin{array}{c}10 \mathrm{H}-6(105-107) \text { to } 11 \mathrm{H}-1 \text { (106-108) } \\
89.9-91.9 \mathrm{mbsf} \\
\end{array}$ & - \\
\hline & $\begin{array}{l}\text { E. fridtjofnanseni/C. } \\
\text { reuschi }\end{array}$ & $\begin{array}{c}16 \mathrm{H}, \mathrm{CC} \text { to } 18 \mathrm{H}-4(24-26) \\
138.0-152.5 \mathrm{mbsf}\end{array}$ & $\begin{array}{c}17 \mathrm{H}-3(25-27) \text { to } 19 \mathrm{H}-2(25-27) \\
133.3-150.8 \mathrm{mbsf}\end{array}$ & - & $\begin{array}{c}11 \mathrm{H}-2(106-108) \text { to } 11 \mathrm{H}, \mathrm{CC} \\
93.4-100.3 \mathrm{mbsf}\end{array}$ & - \\
\hline & Eucoronis fridtjofnanseni & $\begin{array}{c}18 \mathrm{H}-5(24-26) \text { to } 19 \mathrm{H}-5(24-26) \\
154.0-163.9 \mathrm{mbsf}\end{array}$ & $\begin{array}{c}19 \mathrm{H}-3(25-27) \text { to } 20 \mathrm{H}-2(25-27) \\
152.3-160.3 \mathrm{mbsf}\end{array}$ & - & - & - \\
\hline & Clathrospyris vogti & - & - & - & $\begin{array}{c}12 \mathrm{H}-1(105-107) \text { to } 12 \mathrm{H}-2(105-107) \\
101.4-102.9 \mathrm{mbsf}\end{array}$ & - \\
\hline & $\begin{array}{l}\text { Pseudodictyophimus } \\
\text { horrida }\end{array}$ & $\begin{array}{c}20 \mathrm{H}-1 \text { (24-26) to } 21 \mathrm{H}-5(24-26) \\
167.6-183.3 \mathrm{mbsf}\end{array}$ & $\begin{array}{c}20 \mathrm{H}-7(25-27) \text { to } 22 \mathrm{H}-3(25-27) \\
167.8-180.8 \mathrm{mbsf}\end{array}$ & - & $\begin{array}{c}12 \mathrm{H}-3\left(\begin{array}{c}(105-107) \text { to } 13 \mathrm{H}-3(105-107) \\
104.4-113.8 \mathrm{mbsf}\end{array}\right. \\
\end{array}$ & - \\
\hline & Actinomma plasticum & $\begin{array}{c}21 \mathrm{H}-6(24-26) \text { to } 22 \mathrm{H}-1(24-26) \\
184.8-187.0 \mathrm{mbsf}\end{array}$ & $\begin{array}{c}22 \mathrm{H}-4(25-27) \text { to } 23 \mathrm{H}-2(24-26) \\
182.3-186.0 \mathrm{mbsf} \\
\end{array}$ & - & - & - \\
\hline & $\begin{array}{l}\text { Cyrtocapsella kladaros } \\
\text { Subzone b }\end{array}$ & $\begin{array}{c}22 \mathrm{H}-2(75-77) \text { to } 22 \mathrm{H}-3(75-77) \\
188.5-190.0 \mathrm{mbsf}\end{array}$ & $\begin{array}{c}23 \mathrm{H}-3(24-26) \text { to } 23 \mathrm{H}, \mathrm{CC} \\
187.5-192.4 \mathrm{mbsf}\end{array}$ & $\begin{array}{l}2 \mathrm{X}-1(25-27) \\
190.2 \mathrm{mbsf}\end{array}$ & - & - \\
\hline
\end{tabular}


Table 2 (continued).

\begin{tabular}{|c|c|c|c|c|c|c|}
\hline & Zone/Assemblage & Hole $642 \mathrm{~B}(\mathrm{~cm})$ & Hole $642 \mathrm{C}(\mathrm{cm})$ & Hole $642 \mathrm{D}(\mathrm{cm})$ & Hole $643 \mathrm{~A}(\mathrm{~cm})$ & Hole $644 \mathrm{~A}(\mathrm{~cm})$ \\
\hline \multirow{12}{*}{ 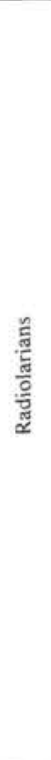 } & $\begin{array}{l}\text { Cyrtocapsella kladaros } \\
\text { Subzone a }\end{array}$ & $\begin{array}{c}22 \mathrm{H}-4(75-77) \text { to } 22 \mathrm{H}-5(75-77) \\
191.5-193.0 \mathrm{mbsf}\end{array}$ & $\begin{array}{c}24 \mathrm{H}-1(25-27) \text { to } 24 \mathrm{H}-2(25-27) \\
192.7-194.2 \mathrm{mbsf}\end{array}$ & $\begin{array}{c}2 X-2(25-27) \text { to } 2 X-4(25-27) \\
191.7-194.7 \mathrm{mbsf}\end{array}$ & $\begin{array}{l}13 \mathrm{H}-4(104-106) \text { to } 13 \mathrm{H}, \mathrm{CC} \\
115.4-119.3 \mathrm{mbsf}\end{array}$ & - \\
\hline & Ceratocyrtis broeggeri & $\begin{array}{l}22 \mathrm{H}-6 \text { (75-77) to } 22 \mathrm{H}, \mathrm{CC} \\
194.5-196.0 \mathrm{mbsf}\end{array}$ & $\begin{array}{c}24 \mathrm{H}-3(25-27) \text { to } 24 \mathrm{H}-4(25-27) \\
195.7-197.2 \mathrm{mbsf}\end{array}$ & $\begin{array}{l}2 X-6(25-27) \\
197.7 \mathrm{mbsf}\end{array}$ & $\begin{array}{c}14 \mathrm{H}-1 \text { (109-111) to } 15 \mathrm{H}-4 \text { (15-17) } \\
120.4-133.6 \mathrm{mbsf}\end{array}$ & - \\
\hline & Cyrtocapsella eldholmi & $\begin{array}{c}23 \mathrm{H}-1 \text { (75-77) to } 23 \mathrm{H}-3 \text { (75-77) } \\
196.8-199.8 \mathrm{mbsf}\end{array}$ & $\begin{array}{l}24 \mathrm{H}-5(25-27) \text { to } 24 \mathrm{H}, \mathrm{CC} \\
198.7-199.6 \mathrm{mbsf}\end{array}$ & $\begin{array}{l}2 X, C C \text { to } 3 X-2(25-27) \\
199.7-201.4 \mathrm{mbsf}\end{array}$ & - & - \\
\hline & Ceratocyrtis manumi & - & - & - & $\begin{array}{l}\text { 15H-5 (105-107) to } 17 \mathrm{X}, \mathrm{CC} \\
135.9-148.5 \mathrm{mbsf}\end{array}$ & - \\
\hline & $\begin{array}{l}\text { Cycladophora davisiana } \\
\text { cornutoides }\end{array}$ & - & - & - & $\begin{array}{c}18 \mathrm{X}-1(105-107) \text { to } 20 \mathrm{X}-2(105-107) \\
158.4-178.9 \mathrm{mbsf}\end{array}$ & - \\
\hline & Spongotrochus vitabilis & - & - & - & $\begin{array}{c}20 \mathrm{X}-3(105-107) \text { to } 20 \mathrm{X}-5(105-107) \\
180.4-183.4 \mathrm{mbsf}\end{array}$ & - \\
\hline & $\begin{array}{l}\text { Pseudodictyophimus } \\
\text { amundseni }\end{array}$ & $\begin{array}{l}23 \mathrm{H}-4(75-77) \text { to } 23 \mathrm{H}, \mathrm{CC} \\
201.3-205.6 \mathrm{mbsf}\end{array}$ & - & $\begin{array}{l}3 \mathrm{X}-3(25-27) \text { to } 3 \mathrm{X}, \mathrm{CC} \\
202.9-207.5 \mathrm{mbsf}\end{array}$ & $\begin{array}{l}21 X-1 \text { (35-37) to } 23 X-4 \text { (105-107) } \\
186.2-210.7 \mathrm{mbsf}\end{array}$ & - \\
\hline & $\begin{array}{l}\text { Corythospyris jabata } \\
\text { sverdrupi }\end{array}$ & $\begin{array}{c}24 \mathrm{H}-1 \quad(75-77) \text { 10 } 24 \mathrm{H}-5(75-77) \\
206.4-212.4 \mathrm{mbsf}\end{array}$ & - & 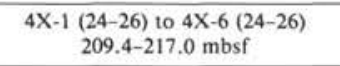 & 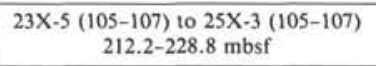 & - \\
\hline & Clathrospyris sandellae & $\begin{array}{c}24 \mathrm{H}, \mathrm{CC} \text { to } 25 \mathrm{H}, \mathrm{CC} \\
213.0-221.1 \mathrm{mbsf}\end{array}$ & - & $\begin{array}{l}4 X, C C \text { to } 5 X, C C \\
218.9-228.5 \mathrm{mbsf}\end{array}$ & $\begin{array}{c}25 \mathrm{X}-4(105-107) \text { to } 27 \mathrm{X}, \mathrm{CC} \\
230.3-254.0 \mathrm{mbsf}\end{array}$ & - \\
\hline & $\begin{array}{l}\text { Gondwanaria japonica } \\
\text { kiaeri }\end{array}$ & - & - & $\begin{array}{c}6 \mathrm{X}-1 \text { (30-32) to } 8 \mathrm{X}-3(25-27) \\
228.8-251.5 \mathrm{mbsf}\end{array}$ & $\begin{array}{c}28 \mathrm{X}-1 \text { (105-107) to } 30 \mathrm{H}, \mathrm{CC} \\
255.2-274.2 \mathrm{mbsf}\end{array}$ & - \\
\hline & Eucyrtidium saccoi & - & - & $\begin{array}{c}8 X-4(25-27) \text { to } 9 X, C C \\
253.0-267.1 \mathrm{mbsf}\end{array}$ & - & - \\
\hline & $\begin{array}{l}\text { Actinomma hennings- } \\
\text { moeni }\end{array}$ & - & - & $\begin{array}{c}10 X-1(25-27) \text { to } 11 X-1 \text { (65-67) } \\
267.4-277.5 \mathrm{mbsf}\end{array}$ & - & - \\
\hline \multirow{11}{*}{ 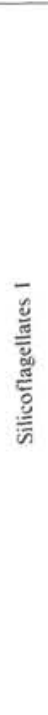 } & Distephanus speculum & - & - & - & - & $\begin{array}{c}32 \mathrm{H}-1(70-72) \text { to } 34 \mathrm{H}-5(70-72) \\
240.3-252.7 \mathrm{mbsf}\end{array}$ \\
\hline & $\begin{array}{l}\text { Distephamus jimlingii } \\
\text { Subzone } \mathrm{b}\end{array}$ & - & $\begin{array}{l}9 \mathrm{H}-2(103-105) \\
63.2 \mathrm{mbsf}\end{array}$ & - & - & - \\
\hline & $\begin{array}{l}\text { Distephanus jimlingii } \\
\text { Subzone a }\end{array}$ & - & $\begin{array}{l}10 \mathrm{H}-2(124-126) \text { to } 11 \mathrm{H}-5(14 \mathrm{l}-143) \\
66.2-80.4 \mathrm{mbsf}\end{array}$ & - & - & - \\
\hline & Distephanus boliviensis & - & $\begin{array}{c}12 \mathrm{H}-2(120-122) \text { to } 15 \mathrm{H}-2(125-127) \\
85.2-113.8 \mathrm{mbsf}\end{array}$ & - & - & - \\
\hline & $\begin{array}{l}\text { Bachmannocena diodon } \\
\text { nodosa }\end{array}$ & - & $\begin{array}{c}\text { 15H-5 (125-127) to } 17 \mathrm{H}-2(126-129) \\
118.3-132.8 \mathrm{mbsf}\end{array}$ & - & $\begin{array}{l}8 \mathrm{H}-5(67-69) \text { to } 10 \mathrm{H}-5(68-70) \\
70.0-88.0 \mathrm{mbsf}\end{array}$ & - \\
\hline & $\begin{array}{l}\text { Distephanus crux scutula- } \\
\text { tus }\end{array}$ & - & $\begin{array}{c}17 \mathrm{H}-5(125-127) \text { to } 19 \mathrm{H}-5(125-128) \\
137.3-156.3 \mathrm{mbsf}\end{array}$ & $\begin{array}{ll}- \\
-\end{array}$ & $\begin{array}{c}11 \mathrm{H}-1 \text { (70-72) to } 11 \mathrm{H}-2(70-72) \\
91.5-93.0 \mathrm{mbsf}\end{array}$ & - \\
\hline & $\begin{array}{l}\text { Bachmannocena circulus } \\
\text { var. apiculata/Caryo- } \\
\text { cha }\end{array}$ & - & $\begin{array}{l}20 \mathrm{H}-2(125-128) \\
161.3 \mathrm{mbsf}\end{array}$ & - & $\begin{array}{l}12 \mathrm{H}-2(70-72) \\
102.5 \mathrm{mbsf}\end{array}$ & - \\
\hline & Caryocha ernestinae & - & $\begin{array}{c}20 \mathrm{H}-5(125-128) \text { to } 21 \mathrm{H}-2(125-128) \\
165.8-170.8 \mathrm{mbsf}\end{array}$ & - & $\begin{array}{l}12 \mathrm{H}-5(70-72) \\
107.0 \mathrm{mbsf}\end{array}$ & - \\
\hline & $\begin{array}{l}\text { Distephanus speculum } \\
\text { hemisphaericus }\end{array}$ & - & $\begin{array}{c}21 \mathrm{H}-5(125-128) \text { to } 24 \mathrm{H}-5(125-128) \\
175.3-199.7\end{array}$ & $\begin{array}{c}3 \mathrm{X}-1 \text { (125-127) to } 6 \mathrm{X}-2(125-128) \\
191.2-231.3 \mathrm{mbsf} \\
\end{array}$ & $\begin{array}{c}13 \mathrm{H}-2(70-72) \text { to } 27 \mathrm{H}-6(70-72) \\
112.0-252.5 \mathrm{mbsf}\end{array}$ & - \\
\hline & Naviculopsis ponticula & - & - & $\begin{array}{l}6 \mathrm{XX}-4(115-117) \\
234.2 \mathrm{mbsf}\end{array}$ & $\begin{array}{c}27 X, \mathrm{CC} \\
254.0 \mathrm{mbsf}\end{array}$ & - \\
\hline & Naviculopsis quadrata & - & - & $\begin{array}{c}7 \mathrm{X}-2(120-122) \text { to } 8 \mathrm{X}-2(122-124) \\
240.9-250.5 \mathrm{mbsf}\end{array}$ & $\begin{array}{c}28 \mathrm{X}-6 \text { (70-72) to } 29 \mathrm{X}-5 \text { (70-72) } \\
262.3-270.6 \mathrm{mbsf}\end{array}$ & - \\
\hline
\end{tabular}


Table 2 (continued).

\begin{tabular}{|c|c|c|c|c|c|c|}
\hline & Zone/Assemblage & Hole $642 \mathrm{~B}(\mathrm{~cm})$ & Hole $642 \mathrm{C}(\mathrm{cm})$ & Hole $642 \mathrm{D}(\mathrm{cm})$ & Hole $643 \mathrm{~A}(\mathrm{~cm})$ & Hole $644 \mathrm{~A}(\mathrm{~cm})$ \\
\hline - & Naviculopsis lata & - & - & $\begin{array}{c}8 \mathrm{X}-5(122-124) \text { to } 10 \mathrm{X}-5(110-113) \\
253.9-274.2 \mathrm{mbsf}\end{array}$ & & \\
\hline \multirow{10}{*}{ 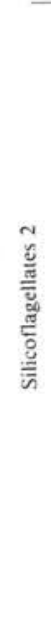 } & Mesocena quadrangula & - & - & - & - & $\begin{array}{c}10 \mathrm{H}-3,74-75) \text { to } 12 \mathrm{H}-5(66-67) \\
86.4-108.4 \mathrm{mbsf}\end{array}$ \\
\hline & Distephanus speculum & - & - & - & - & $\begin{array}{c}10 \mathrm{H}-2(74-75) \text { to } 23 \mathrm{H}-2(55-56) \\
84.9-196.2 \mathrm{mbsf}\end{array}$ \\
\hline & Distephanus aculeatus & - & $\begin{array}{c}9 \mathrm{H}-1 \text { (64-65) to } 13 \mathrm{H}-2 \text { (66-67) } \\
61.3-94.2 \mathrm{mbsf}\end{array}$ & - & - & $\begin{array}{c}30 \mathrm{H}-2(56-57) \text { to } 34 \mathrm{H}-5(66-67) \\
228.2-252.7 \mathrm{mbsf}\end{array}$ \\
\hline & Mesocena diodon & - & $\begin{array}{c}13 \mathrm{H}-3(30-31) \text { to } 15 \mathrm{H}-3(66-67) \\
95.3-114.7 \mathrm{mbsf}\end{array}$ & - & - & - \\
\hline & $\begin{array}{l}\text { Paramesocena circulus } \\
\text { apiculata }\end{array}$ & - & $\begin{array}{c}15 \mathrm{H}-4(66-67) \text { to } 19 \mathrm{H}-4(50-51) \\
116.2-154.0 \mathrm{mbsf}\end{array}$ & - & - & - \\
\hline & Distephanus stauracanthus & - & $\begin{array}{l}19 \mathrm{H}-5(50-51) \\
155.5 \mathrm{mbsf}\end{array}$ & - & - & - \\
\hline & $\begin{array}{l}\text { Upper Corbisema triacan- } \\
\text { tha }\end{array}$ & - & $\begin{array}{c}19 \mathrm{H}-5(50-51) \text { to } 22 \mathrm{H}-2(66-67) \\
155.5-179.7 \mathrm{mbsf}\end{array}$ & - & - & - \\
\hline & $\begin{array}{l}\text { Lower Corbisema triacan- } \\
\text { tha }\end{array}$ & - & $\begin{array}{c}22 \mathrm{H}-3(66-67) \text { to } 24 \mathrm{H}-5(70-71) \\
181.2-199.1 \mathrm{mbsf}\end{array}$ & $\begin{array}{c}3 \mathrm{X}-1(60-61) \text { to } 6 \mathrm{X}-2(66-67) \\
200.2-230.7 \mathrm{mbsf}\end{array}$ & - & - \\
\hline & Naviculopsis navicula & - & & $\begin{array}{c}6 \mathrm{X}-3(66-67) \text { to } 9 \mathrm{X}-4(70-71) \\
232.2-267.7 \mathrm{mbsf}\end{array}$ & - & - \\
\hline & Naviculopsis lata & - & & $\begin{array}{l}\text { 9X-5 (70-71) to 11X-1 (55-56) } \\
264.2-277.4 \mathrm{mbsf}\end{array}$ & - & - \\
\hline
\end{tabular}


foraminifers and calcareous nannofossils have been studied in greater detail in Hole 642B than in Hole 642C. Radiolarians are the only group of siliceous microfossils that have been investigated in Hole 642B for this volume. Dinoflagellates have been examined by Mudie (this volume) only for the upper $167.4 \mathrm{~m}$ of the hole (Cores 104-642B-1H to -642B-19H).

The first occurrence of Neogloboquadrina mayeri (planktonic foraminifers) at $167 \mathrm{mbsf}$ is approximately $3 \mathrm{~m}$ below the bases of the other calcareous microfossil zones (the boundary between lithologic Units IID and III). This horizon is also marked by the abrupt base of the Eucoronis fridtjofnanseni Zone, which is inferred to be unconformable with the underlying Interzone B. The base of lithologic Unit IIB (105 mbsf) is approximately coincident with the base of the Liriospyis cricus Zone. Other approximately coeval horizons include: the bases of the Filisphaera filifera Zone (dinoflagellates) and Pseudodictyophimus gracilipes tetracanthus Zones (radiolarians) at 76-78 mbsf and the bases of the Achomosphaera andalousiensis Zone (dinoflagellates) and Corythospyris reuschi Zone (radiolarians) at 138 mbsf. The top of the E. fridtjofnanseni Zone (radiolarians) is approximately coeval with the top of the Bolboforma reticulata Zone at 155 mbsf. The youngest occurrence of significant radiolarians in Hole 642B (66 mbsf) falls within the Pseudodictyophimus gracilipes Zone, which is approximately equivalent to the tops of the Cassidulina laevigata/Epistominella exigua Zone (benthic foraminifers) and Neogloboquadrina atlantica (sin.) Zone (planktonic foraminifers).

Skogseid and Eldholm (this volume) identified two seismic reflectors above the Unit II/III unconformity. The upper reflector, UP, is regarded as representing the base of Unit I (65.7 mbsf). This contact is approximately coincident with the tops of the $N$. atlantica (sin.) Zone (planktonic foraminifers) and Pseudodictyophimus gracilipes tetracanthus Zone (radiolarians). Although this horizon in Hole 642B is interpreted in this synthesis as the location of a $0.5-\mathrm{m} . \mathrm{y}$. hiatus, its status as a regional unconformity is uncertain. If reflector UP is a sequence boundary, however, an alternative location is in the interval 112-130 mbsf (Cores 104$642 \mathrm{~B}-14 \mathrm{H}$ to $-642 \mathrm{~B}-15 \mathrm{H})$, which is marked by the approximate tops of the Bolboforma metzmacheri Zone (Bolboforma) and Neogloboquadrina atlantica dex. Zone (planktonic foraminifers) as well as the top of the Hexalonche esmarki Zone. The $H$. esmarki Zone is regarded by Goll and Bjørklund (this volume) as occupying an interval of rapid turnover in the radiolarian assemblage. The poor recovery in Core 104-642B-14H may be a further manifestation of an unconformity within this interval. The lower reflector, MM, is positioned at approximately 200 mbsf (mid Core 104-642B-23H, which is interpreted in this synthesis as occupied by a $1.5-\mathrm{m}$.y.-hiatus. This horizon is distinguished by the bases of the Martinottiella communis zone (benthic foraminifers) and Cyrtocapsella eldholmi Zone (radiolarians). The $C$. eldholmi Zone is regarded as an interval of rapid turnover in the radiolarian assemblage by Goll and Bjørklund (this volume).

\section{Hole $642 C$}

Two separate silicoflagellate biozonations are presented by Ciesielski, Hasson, and Turner (this volume) and Locker and Martini (this volume). Dinoflagellates below 84 mbsf (Cores $104-642 C-12 X$ to $-642 C-24 X)$ have been investigated by Manum et al. (this volume). The Pliocene-Pleistocene dinoflagellate zones of Mudie (this volume, the Multispinula minuta/Brigantedinium simplex and Filisphaera filifera Zones) are not recorded for Hole $642 \mathrm{C}$.

The bases of the calcareous microfossil zones at approximately 160 mbsf are coeval with the bases of the $E$. fridtjofnanseni Zone (radiolarians) and Distephanus crux scutulatus Zone (silicoflagellates). Slightly higher at $158 \mathrm{mbsf}$, the base of Zones
NN7-NN15 (calcareous nannofossils) appears to be synchronous with the bases of the Neogloboquadrina acostaensis Zone (planktonic foraminifers) and the upper Corbisema triacantha Zone (silicoflagellates).

Coincidence of the bases of the A. andalousiensis Zone (dinoflagellates) and $C$. reuschi Zone (radiolarians) observed in Hole $642 \mathrm{~B}$ is not evident in Hole $642 \mathrm{C}$ because of a palynomorph-barren interval, but the base of the latter zone appears to be very closely coeval with the base of the $B$. diodon nodosa Zone (silicoflagellates), and is approximately coeval with the top of the Bolboforma fragori Zone. As in Hole 642B, the top of the E. fridtjofnanseni Zone (radiolarians) at $152 \mathrm{mbsf}$ in Hole $642 \mathrm{C}$ is approximately concident with the top of the $B$. reticulata Zone, and the base of lithologic Unit IIA is approximately coincident with the base of the $L$. cricus Zone (radiolarians).

The base of the Bolboforma fragori Zone is approximately coeval with the base of the $P$. clathratum Zone (ebridians). Interestingly, the base of the $M$. communis Zone (benthic foraminifers) is not coincident with the base of the C. eldholmi Zone in Hole 642C, as was observed in Hole 642B. The boundary between lithologic Units IIA and IIB is located just above the top of the Liriospyris cricus Zone (designated as the Miocene/Pliocene boundary criterion for Leg 104) and is approximately coeval with the top of the Parathranium clathratium Zone (ebridians).

The youngest preservation of significant quantities of siliceous microfossils at approximately 62 mbsf occurs within the Ebriopsis cornuta Zone (ebridians), Pseudodictyophimus gracilipes tetracanthus Zone (radiolarians), and Distephanus jimlingii and Distephanus aculeatus Zones (silicoflagellates), and is approximately coincident with the tops of the $C$. laevigata/E. exigua Zone (benthic foraminifers) and $N$. atlantica (sin.) Zone (planktonic forminifers).

Within the depth interval 114-124 mbsf, there are zonal boundaries for all the biozonations except Bolboforma (generally poorly preserved above $125 \mathrm{mbsf}$ ) and ebridians-actiniscidians. Approximately coincident zone bases in this interval include: the Cassidulina laevigata/Epistominella exigua, Neogloboquadrina atlantica (sin.), Achomosphaera andalousiensis, Tessarastrum thiedei, Distephanus boliviensis, and Mesocena diodon Zones. This is the depth range suggested as the possible alternative position for reflector UP in the discussion of Hole 642B. The upper interval of rapid turnover in the radiolarian assemblages $(C$. reuschi to $H$. esmarki Zones) is generally characterized by poor preservation of both calcareous microfossils and palynomorphs. Poor palynomorph preservation is prevalent throughout much of the older interval of rapid radiolarian assemblage turnover in the $C$. eldholmi Zone as well. The location of reflector MM is probably just below the bottom of Hole $642 \mathrm{C}$.

\section{Hole $642 D$}

In Hole 642D, the same fossil groups have been examined by the same specialists as in Hole $642 \mathrm{C}$. Bolboforma, calcareous nannofossils, and planktonic foraminifers are barren throughout this hole, and benthic foraminifers are absent below 272 mbsf (mid Core 104-642D-10X). Although sparse silicoflagellates have been found in upper lithologic Unit IV (Cores 104642D-11X to 642D-12X), they are not regarded as in situ, and siliceous microfossils are assigned to zones only to the base of lithologic Unit III at 278 mbsf. Below this depth, only dinoflagellates have been studied biostratigraphically for this volume, and the lower Miocene Evittosphaerula paratabulata Zone is recorded as resting unconformably on lower Eocene sediments.

The bases of Clathrospyris sandellae Zone (radiolarians), Distephanus speculum hemisphaericus, and lower Corbisema triacantha Zones (silicoflagellates) are approximately coeval at 


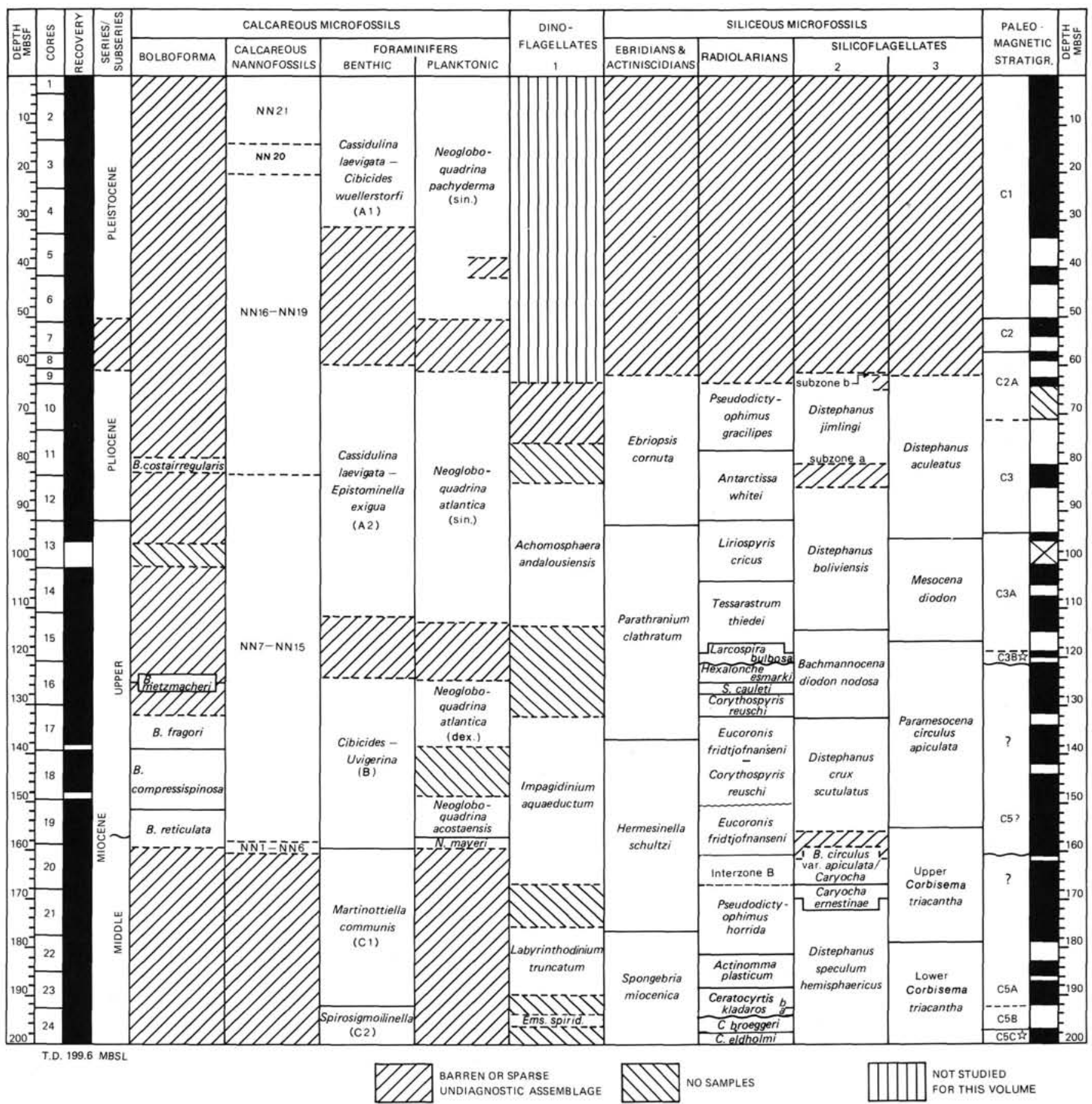

Figure 3. Comparison of biozonations presented in this volume for Hole 642C. 1, Manum et al. (this volume); 2, Cielsielski, Hasson and Turner (this volume); TD, total depth. The paleomagnetic stratigraphy follows Bleil (this volume). Stars in the chron column indicate that the age attributed to the specific chron by Berggren et al. (1985) is not consistent with the age assigned to these sediments in Figure 9.

228-232 mbsf, and this horizon is interpreted in this synthesis as probably representing a $0.4-\mathrm{m} . \mathrm{y}$. hiatus. Coincidence for the bases of the Gondwanaria japonica kiaeri Zone (radiolarians) and the Naviculopsis quadrata Zone (silicoflagellates) at 250 $252 \mathrm{mbsf}$ is also inferred as resulting from a 1.1-m.y. hiatus.

Reflector MM of Skogseid and Eldholm (this volume) at approximately 200 mbsf (mid-Core 104-642D-3X) is marked by the bases of the $M$. communis (benthic foraminifers) Zone and C. eldholmi Zone (radiolarians).

\section{Site 643}

Lat.: $67^{\circ} 42.9^{\prime} \mathrm{N}$

Long: $1^{\circ} 02.0^{\prime} \mathrm{E}$

Water depth: $2753 \mathrm{~m}$

\section{Hole $643 \mathrm{~A}$}

Ebridians and actiniscidians in Hole 643A have not been examined for this volume. The silicoflagellate biozonation of Ciesi- 


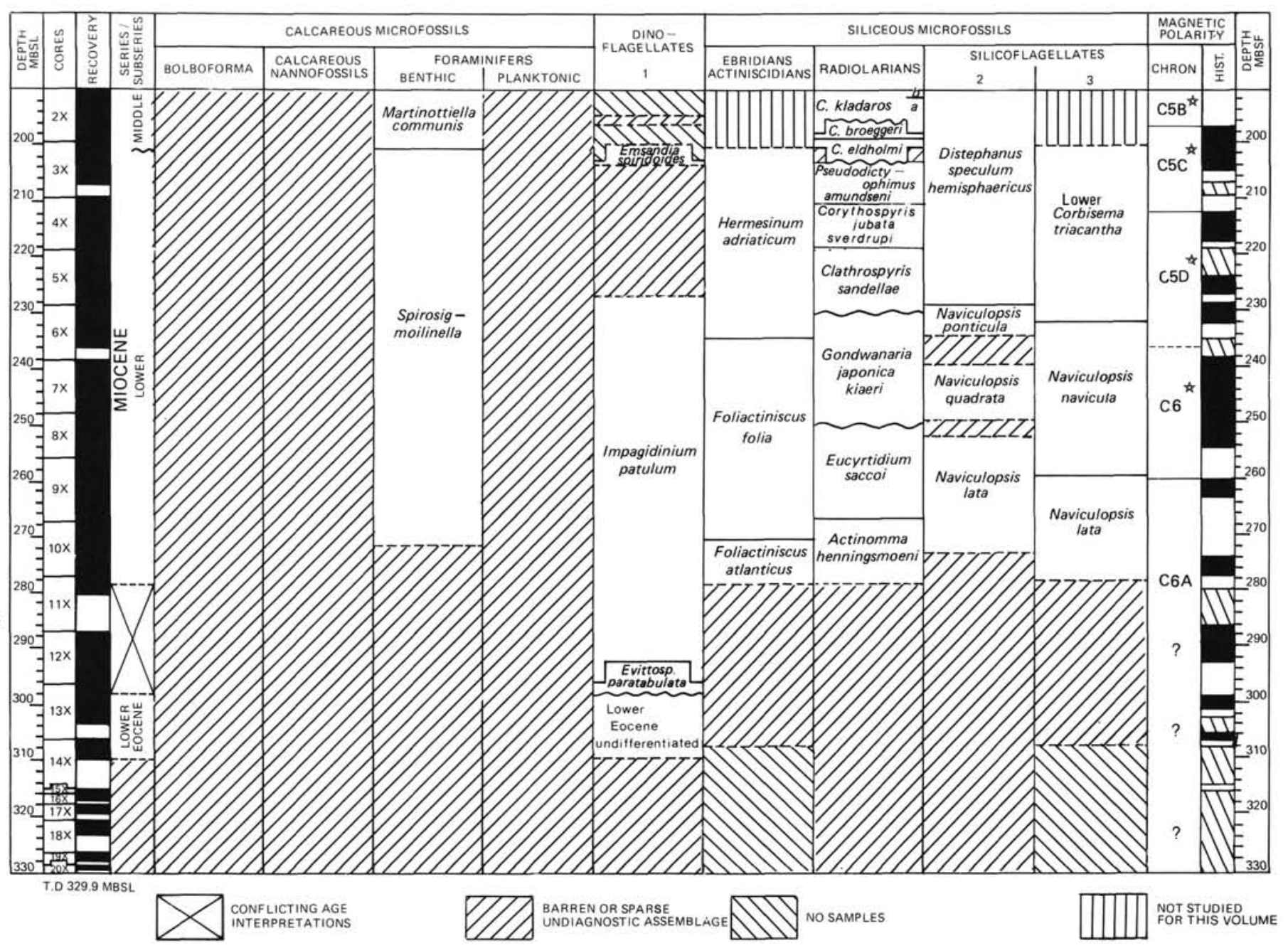

Figure 4. Comparison of biozonations presented in this volume for Hole 642D. 1, Manum et al. (this volume); 2, Ciesielski, Hasson, and Turner (this volume); 3, Locker and Martini (this volume); TD, total depth. The paleomagnetic stratigraphy follows Bleil (this volume). Stars in the chron column indicate that the age attributed to the specific chron by Berggren et al. (1985) is not consistent with the age assigned to these sediments in Figure 9.

elski, Hasson, and Turner (this volume) is presented in Figure 5. All 17 dinoflagellate zones proposed by Mudie (this volume) and Manum et al. (this volume) have been recorded for Hole 643A. The Multispinula minuta/Brigantedinium simplex and Filisphaera filifera Zones have been recognized by Mudie (this volume) for the upper $65 \mathrm{~m}$ of the hole (Cores 104-643A-1H to $-643 \mathrm{~A}-6 \mathrm{H})$. The succession of dinoflagellate zones ranging from the Achomosphaera andalousiensis to the Rottnestia borussica Zones are taken from Manum et al. (this volume). Occurrences of Bolboforma are restricted largely to lithologic Unit IIC but range up into the lower part for Unit IIB. Bolboforma are not recorded in more carbonate-rich Unit IIA. The base of consistent carbonate preservation at 102 mbsf (upper Core 104-643A-12H) is approximately coeval with the bases of the Achomosphaera andalousiensis Zone (dinoflagellates), Eucoronis fridtjofnanseni/ Corythspyris reuschi Zone (radiolarians) and Distephanus crux scutulatus Zone (silicoflagellates). The E. fridtjofnanseni Zone (radiolarians) is not recorded in Hole 643A. The coincidence of so many biostratigraphic boundaries is regarded as evidence of a major hiatus. The lowest occurrence of calcareous benthic foraminifers (marked by the base of the Cibicides/Uvigerina Zone) appears to be slightly above the lowest occurrence of other calcareous microfossil groups, but this may be a sampling artifact. The great thicknesses of the Spirosigmoilinella and Haplophrag- moides walteri Zones (benthic foraminifers) of Osterman and Qvale (this volume) are apparent in Figure 5. The base of the Spirosigmoilinella Zone does not coincide with a lithologic or chronostratigraphic unit boundary, but it is approximately coincident with the base of the Evittosphaerula paratabulata Zone (dinoflagellates). The boundary between calcareous nannofossil zones NNI-NN6 and NP25 is approximately coincident with the contact between lithologic Units IV and V.

The bases of the oldest radiolarians and silicoflagellate zones are approximately coincident with the base of lithologic Unit III, which occurs in the upper part of the E. paratabulata Zone (dinoflagellates). The youngest siliceous microfossils that have been treated biostratigraphically [the tops of the $H$. esmarki (radiolarians) and Bachmannocena diodon nodosa (silicoflagellate) Zones at 62 and $68 \mathrm{mbsf}$, respectively] are approximately coeval with the tops of the Cibicides/Uvigerina Zone (benthic foraminifers), $N$. atlantica (dex.) Zone (planktonic foraminifers) and $A$. andalousiensis Zone (dinoflagellates). Thus, termination of opal preservation occurs five radiolarian zones and two silicoflagellate zones (Ciesielski) lower in Hole 643A than in Hole 642C.

Four middle to lower Miocene radiolarian zones, Ceratocyrtis broeggeri, Ceratocyrtis manumi, Cycladophora davisiana cornutoides, and Spongotrochus vitabilis, are recognized only in Hole 
$643 \mathrm{~A}$, and their occurrence is largely restricted to the E. spiridoides Zone (dinoflagellates). The top of the $E$. fridtjofnanseni/C. reuschi Zone (radiolarians) is coeval with the top of the Bolboforma fragori Zone.

Reflector UP of Skogseid and Eldholm (this volume), which is thought to represent the contact between lithologic Units I and II, is recognizable biostratigraphically only by the base of the Neogloboquadrina pachyderma (sin.) Zone. Reflector MM is regarded as occupying a depth of approximately $200 \mathrm{mbsf}$, which is distinguished biostratigraphically only by the top of the Impagidinium patulum Zone (dinoflagellates). If reflector MM represents a sequence boundary, however, its location is more probably at 134 mbsf. This horizon is marked by the approximate bases of the Ceratocyrtis broeggeri Zone (radiolarians) and Labyrinthodinium truncatum Zone (dinoflagellates). A 0.3-m.y. hiatus is inferred to occur at this depth, but the hiatus may have a longer duration. The lower Miocene Reflector A (upper lithologic Unit IV) is not recognizable biostratigraphically. Reflector TO is distinguished by the bases of zones NN1-NN6 (calcareous nannofossils) and the Ascostomocystis granosa Zone (dinoflagellates). Reflectors $\mathrm{A}^{\prime}$ and $\mathrm{ME}$ are possibly distinguishable by the bases of the Impagidinium sp. 1 and Chiropteridium lobospinosum Zones.

\section{SITE 644}

Lat.: $66^{\circ} 40.7^{\prime} \mathrm{N}$

Long.: $4^{\circ} 34.6^{\prime} \mathrm{E}$

Water depth $1227 \mathrm{~m}$

\section{Hole $644 \mathrm{~A}$}

The silicoflagellate biostratigraphy of Hole $644 \mathrm{~A}$ has been investigated by both Ciesielski et al. (this volume) and Locker and Martini (this volume). The dinoflagellate biostratigraphy of this hole has been the subject of study by Mudie (this volume).

With the exception of a single specimen of Bolboforma costairregularis (? contamination) in Core 104-644A-14H, Bolboforma are absent in Hole 644A. The upper $N$. atlantica (dex.) Zone (planktonic foraminifers) have been recognized only at Site 644. The youngest occurrences of biostratigraphically significant siliceous microfossils at approximately 85 mbsf are coeval with the base of the $M$. minuta/B. simplex Zone (dinoflagellates) and the base of lithologic Unit IIB. The base of lithologic Unit IA is approximately coincident with the base of Zone NN20 (calcareous nannofossils). The base of lithologic Unit IC is approximately coincident with the youngest occurrences of the Ebriopsis cornuta Zone (ebridians), Spongaster ?tetra Zone (radiolarians), and Distephanus speculum and Distephanus aculeatus Zones (silicoflagellates).

Skogseid and Eldholm (this volume) regard the depth of reflector UP at Site 644 as coincident with the contact between lithologic Units I and II. If this reflector is assumed to represent a sequence boundary and regional unconformity, however, then it alternatively might be located somewhat below the base of Hole $644 \mathrm{~A}$, where a major hiatus equivalent to that of Hole 341 may exist (equivalent to reflector UP of Site 341).

\section{PALEOGENE BIOSTRATIGRAPHY}

Paleogene sections $932.0 \mathrm{~m}$ and $155.2 \mathrm{~m}$ thick were penetrated at Sites 642 and 643, respectively. Sediments of this age at Site 642 are restricted to shale partings intercalated into the upper and lower basalt series and to the overlying pyroclastic muds (Unit IV). Sparse local occurrences of siliceous microfossils as well as numerous occurrences of palynomorphs have been reported for these strata. Eocene and Oligocene compaction-laminated mudstones comprise the lower member of the sediment column at Hole 643A. Although calcareous and siliceous microfossils are present very sporadically in these strata, only palyno- morphs and agglutinated foraminifers have persistent occurrences and provide primary biostratigraphic control. Age determinations for the Paleogene intervals are partially contradictory, and it has been necessary to attempt to draw the most reasonable conclusion from conflicting lines of evidence.

\section{Site 642}

Biostratigraphic data pertaining to the Paleogene succession of Site 642 , as well as the chronostratigraphic interpretations based on these data, are compiled in Figure 7. The palynological studies of the Paleocene succession of Site 642 described in Eldholm, Thiede, Taylor, et al. (1987b) and in this volume are at variance in many important aspects. Rare to moderately common dinocysts were found in 41 of 49 shale parting samples from the upper and lower basalt series Sections (104-642D-15X, CC to -642E-109R-1) by P. Mudie (Eldholm, Thiede, Taylor, et al., 1987b), and the succession was divided into three dinocyst Zones (PM7-PM9). Nine taxa identified in the oldest unit, the Cerebrocysta bartonensis Zone (PM9, Sections 104-642E-55R-2 to -642E-109R-1) include Polysphaeridum congregatum (calcareous nannofossil Zones NP18-NP24 according to Williams and Bujak, 1985) and Polysphaeridum subtile (Zones NP12-NP17), which have not been previously reported to have overlapping ranges. This assemblage was correlated to the middle Eocene Barton Beds (Zones NP16-NP17, according to Aubry, 1985). The eight taxa reported for the overlying unit, the Batiacasphaera compta-Phthanoperidinium echinatum Zone (PM8, Sections 104-642E-4R-1 to -642E-55R-2) represent a significantly different flora. If the zonal boundary critera have stratigraphic ranges in the Norwegian Sea equivalent to their reported ranges from other localities (Williams and Bujak, 1985), this zone would extend from the lower Eocene to the lower Oligocene (Zones NP13-NP21), but a late middle Eocene age was preferred. A second major flora transition marks the base of the third unit, the Chiropteridium dispersum Zone (PM7, Sections 104-642E$4 \mathrm{R}-1$ to $-642 \mathrm{D}-15 \mathrm{X}-\mathrm{CC})$, in which eight species were identified. If the zonal boundary criteria have stratigraphic ranges in the Norwegian Sea equivalent to their reported ranges from other localities (Williams and Bujak, 1985), this zone would extend from the middle to upper Eocene (Zones NP16-NP2O), but a late Eocene age was preferred. The taxa list recorded for this zone includes one species, Melitasphaeridium choanophorum (Zones NP23-NN13), which is anomalously younger than the other flora, and if properly identified, must represent caving contamination.

Assemblages of moderately well-preserved siliceous microfossils in three samples from the upper basalt series (Cores 104642E-35R, -642E-42R, and -642E-55R) were also discussed in Eldholm, Thiede, Taylor, et al. (1987b) by P. Ciesielski. These occurrences are composed mainly of diatoms and silicoflagellates constituted in distinctive floras that were judged to be of probable middle Eocene age based primarly on correlations to antarctic DSDP sites. Unfortunately, further documentation of these important assemblages is not available for this volume.

As a result of a new investigation of palynomorphs in 12 samples from the shale partings of the lower basalt series (Cores 104-642E-102R to -642E-109R), Boulter and Manum (this volume) identified 16 species, only two of which bear the same names as those of the taxa lists of Mudie (Polysphaeridium subtile and Thalassiphora delicata). The authors assign this flora to the Apectodinium hyperacanthum Zone, which is judged to be coeval with lower calcareous nannofossil Zone NP10. This determination is accepted as the best biostratigraphic indication of the age of the lower basalt series, although three of the species included in their taxa list, Hystrichokolpoma rigaudae, Lejeunecysta hyalina, and Polysphaeridium subtile, are reported to range no older than calcareous nannofossil Zones NP11 and NP12 by 


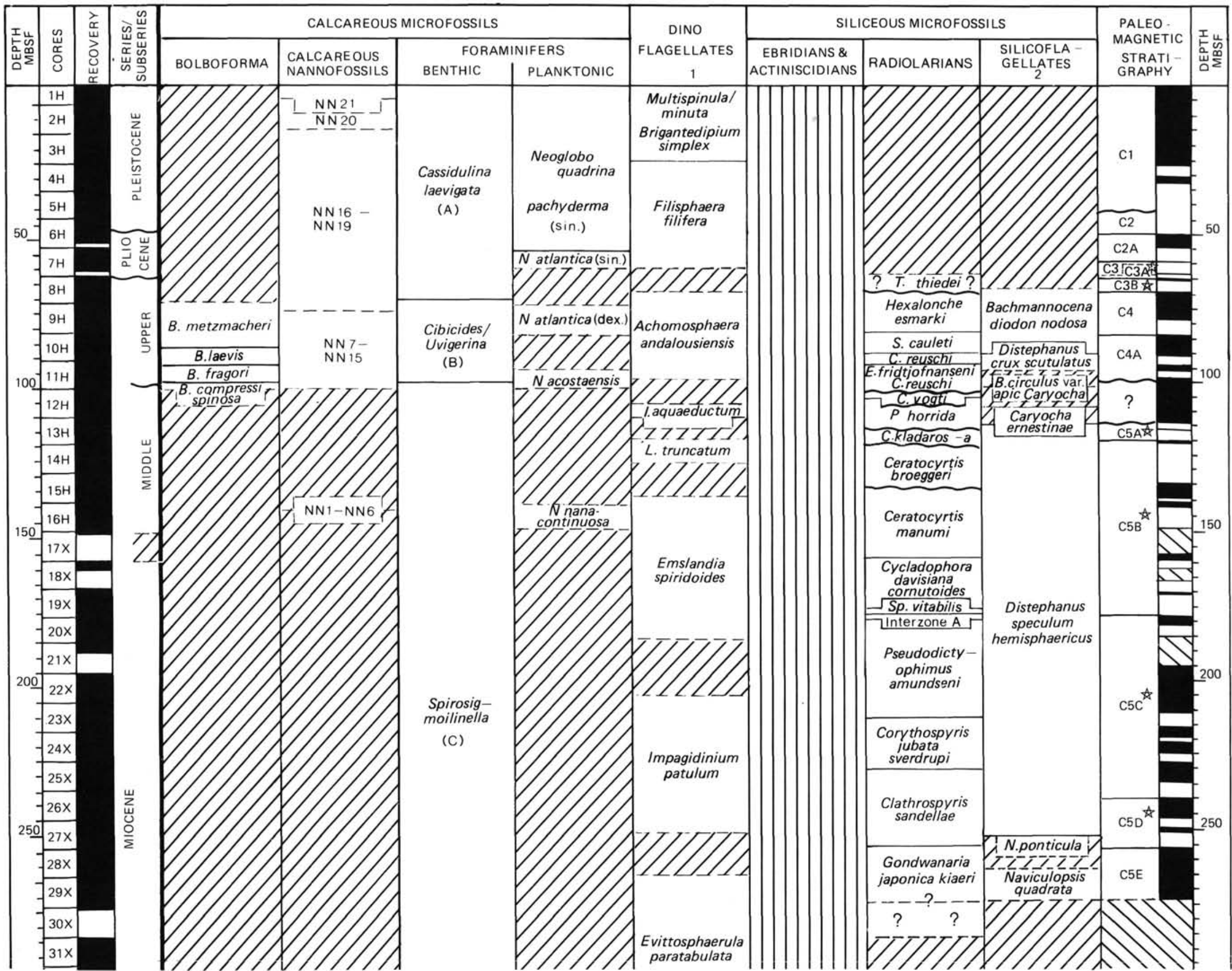




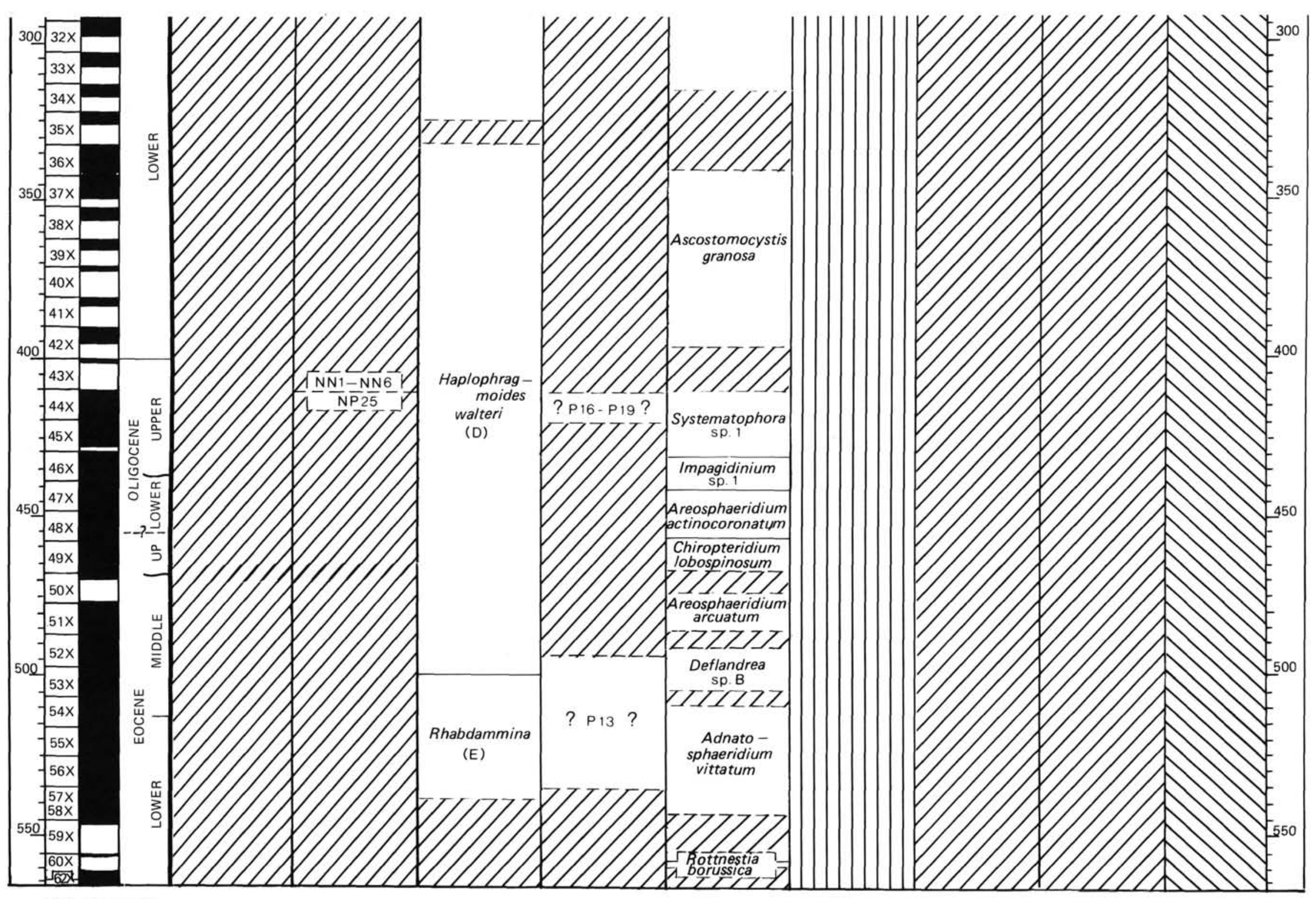

T.D. $565.2 \mathrm{MBSL}$
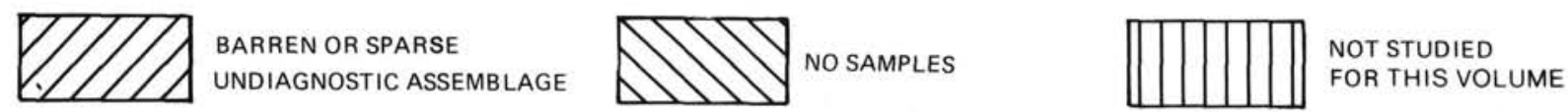

Figure 5. Comparison of biozonations presented in this volume for Hole 643A. 1, Mudie (this volume) for Cores 104-643A-1H to -643A-7H and Manum et al. (this volume) for Cores 104 $643 \mathrm{~A}-8 \mathrm{H}$ to $-643 \mathrm{~A}-62 \mathrm{X} ; 2$, Ciesielski, Hasson, and Turner (this volume); TD, total depth. The paleomagnetic stratigraphy follows Bleil (this volume). Stars in the chron column indicate that the age attributed to the specific chron by Berggren et al. (1985) is not consistent with the age assigned to these sediments in Figure 9. 


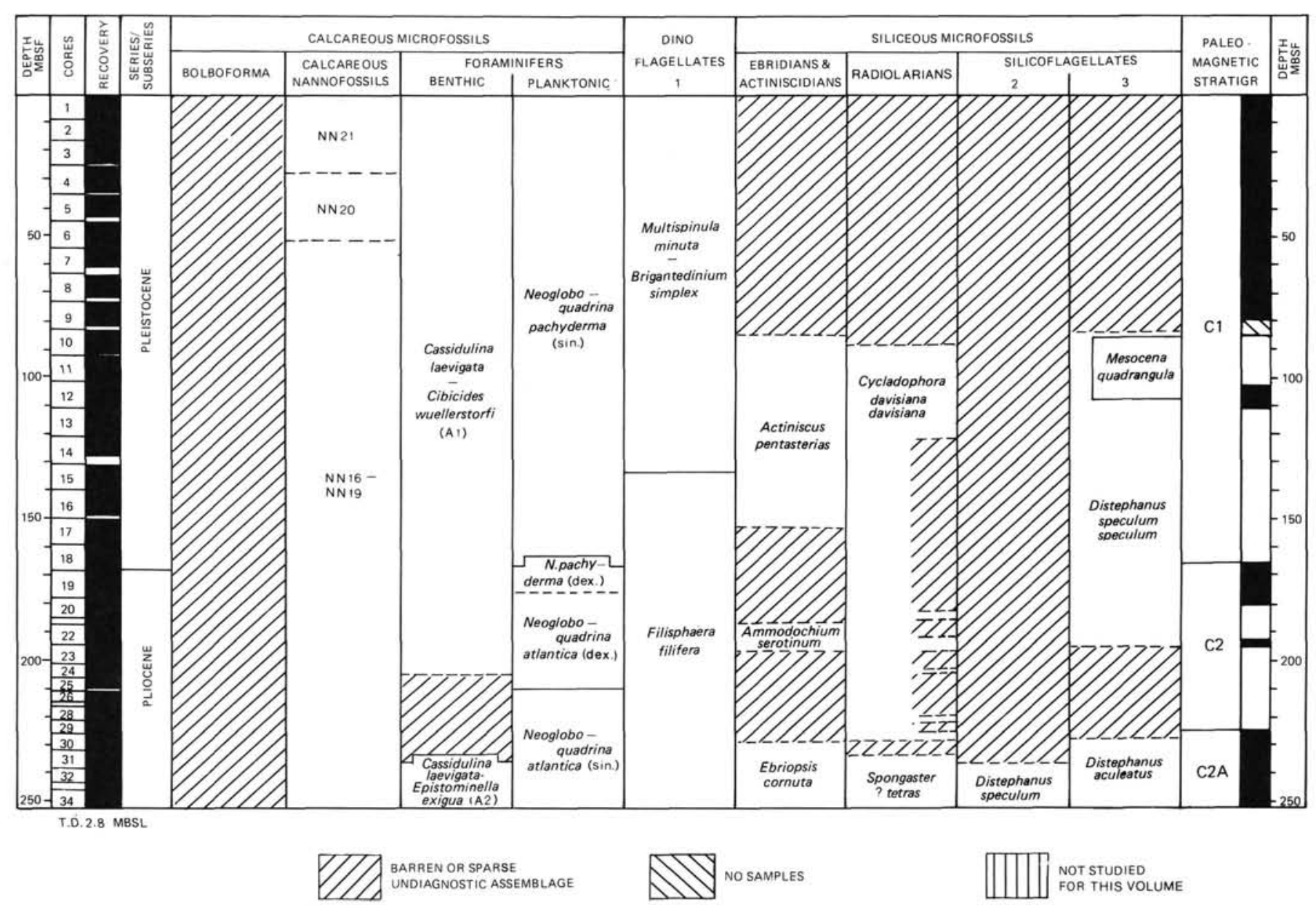

Figure 6. Comparison of the biozonations presented in this volume for Hole 644A. 1, Mudie (this volume); 2, Ciesielski, Hasson, and Turner (this volume); 3, Locker and Martini (this volume); TD, total depth. The paleomagnetic stratigraphy follows Bleil (this volume).

Williams and Bujak (1985). Boulter and Manum made palynologic examinations of numerous (more than 25) independent samples from higher levels of the basalt series, but all of these samples were barren. Unfortunately, there is no verification of the floral transitions for both dinocysts and siliceous microfossils recorded for these intercalations in Eldholm, Thiede, Taylor et al. (1987b).

Resolution of these contradictory biostratigraphic interpretations cannot be achieved without a well-coordinated re-examination of these important rocks. Because the study of Boulter and Manum (this volume) is more thoroughly documented and benefits from more confident taxonomy, the correlation to calcareous nannofossil zone NP10 is accepted for the lower basalt series. With the exception of a weak positive polarity interval in the lower series of Hole 642E, the entire basalt series exhibits negative paleomagnetic polarity, and it seems most reasonable to assume that the thick upper series formed during a short interval of time. Such an assumption is not consistent with the floral fluctuations and younger age determinations (middle to late Eocene) reported by P. Mudie in Eldholm, Thiede, Taylor et al. (1987b) for the sediments from the basalt series above those studied by Boulter and Manum (this volume). Until detailed analyses of these fossils are available, the view of Eldholm, Thiede, and Taylor (this volume) that the entire upper basalt series formed during Chron C24-R2 (56-58.6 Ma) is adopted here.

The basalt series at Site 642 is immediately overlain by $37.6 \mathrm{~m}$ of volcaniclastic and altered volcaniclastic muds, sandy muds, and sand, interpreted as quiet-water shelf to proximal slope deposits (Unit IV, Sections 104-642D-11X-1 to -642D-14X, CC). Cores 104-642D-13X and -642D-14X consist almost entirely of homogeneous and structureless fine-grained muds containing abundant zeolites and glaucony. Sediments in Core 104-642D-12X are more coarse grained than those of Cores 104-642D-13X and $-642 \mathrm{D}-14 \mathrm{X}$ and include numerous thin coarsening-upward beds and cross-bedding structures indicative of mass-flow deposition. The unit is capped by a 10-cm-thick sandy, phosphate-rich hard ground interpreted as having accumulated slowly under weak shallow currents. Similar lithologies occur in the lower sediments of Cores $38-338-30$ to $-338-42$.

In Eldholm, Thiede, Taylor, et al. (1987b), Unit IV was assumed to be Eocene in age, although no fossils were reported for these sediments. Ciesielski, Hasson, and Turner (this volume) and Locker and Martini (this volume) report occurrences of Miocene silicoflagellates and diatoms in Unit IV, which both groups of authors interpret as caving contamination. Samples from this unit are also reported to contain Pleistocene foraminifers (Spiegler and Jansen, this volume), which must represent extreme caving. Manum et al. (this volume) recognize two Miocene dinocyst zones and an unzoned lower Eocene interval in Unit IV. Four samples from the interval 104-642D-13X-3 to $-642 \mathrm{D}-14 \mathrm{X}-2$ contain variably sporadic and more consistent occurrences of 31 dinocyst species, some of which have restricted lower Eocene stratigraphic ranges (including Lanternosphaeridium lanosum, Zones NP10-NP13 according to Williams and 
Bujak, 1985). Particularly noteworthy is the presence of Glaphyrocysta ordinata $(=$ Cyclonephelium ordinatum $)$, which occurs in Hole 338 only in lower Zone VIIa (Manum, 1976). Manum et al. (this volume) conclude that this unzoned lower Eocene flora of Hole 642D is older than the oldest dinocyst flora recovered at Site 643, although the differences in flora composition between these sites may be attributed in part to paleoenvironmental factors. As shown in Figure 11, it is here suggested that this lower Eocene flora is only slightly older than the $R$. borussica Zone assemblage of Hole 643A and is probably coeval with the Zone VI floras of Holes 338 and 343.

On the basis of 35 dinocyst species identified in eight samples from the upper part of Unit IV (Sections 104-642D-11X-2 to -642D-13X-1), Manum et al. (this volume) recognize the Evittosphaerula paratabulata Zone and Impagidinium patulum Zone (both regarded as Miocene). Thus, these authors conclude that this interval is Miocene in age and is separated from the underlying pyroclastics by a major unconformity. This interpretation is the basis of a serious disagreement, because the entire pyroclastic unit is most reasonably assumed to have accumulated during a single undisrupted Eocene sedimentary episode. Few of the species recorded by Manum et al. (this volume) for the upper pyroclastics have global stratigraphic ranges restricted to the Neogene, and an older age for these sediments is conceivable if the younger taxa are regarded as displaced. The flora includes Lejeunecysta spp., which are unique occurrences in Leg 104 sediments, although this genus is reported for upper zone III of Site 338 (Manum, 1976). Because of other indications of caving however, we are inclined to regard these Miocene occurrences as contaminants and conclude that the only in-situ fossils in Unit IV are the lower Eocene assemblages in Sections 104-642D$13 \mathrm{X}-2$ to $-642 \mathrm{D}-14 \mathrm{X}-2$.

All fossils in Sections 104-642D-11X-2 to -642D-13X-1 probably have been introduced either by natural or mechanical displacement, and the age of this interval may be biostratigraphically indeterminate. Extensive caving of younger sediments into the upper pyroclastics, which are probably barren of in-situ fossils, may explain the young ages (37-38 Ma) obtained by isotope datings of fossils from Sections 104-642D-12X-4 and -642D$12 \mathrm{X}-5$ by Smalley, Qvale, and Qvale (this volume). Based on this puzzling data set, it is here concluded that the best indications of the age of Unit IV are the lower Eocene dinocysts in the lower sediments and the lithologic similarity to the lower Eocene sediments at Site 338. Because there is no other evidence that the Vøring Plateau experienced a second younger (Miocene) phase of shallow-water deposition associated with intense volcanism, it seems most appropriate to regard Unit IV as coeval with equivalent strata in Hole 338 (approximately dinocyst Zone VIIa of Manum, 1976).

Younger sediments may have become incorporated into the upper portion of Unit IV as a result of mass flow processes associated with loss or destruction of the original fossils. Such sediment redistribution also may have been responsible for the magnetic polarity reversals in Unit IV (Bleil, this volume). These factors lead us to believe that Unit IV was deposited rapidly (perhaps over no more than $0.5 \mathrm{Ma}$ ), and overlying sediments (later removed by erosion) were incorporated into the upper layer, followed by long exposure of the upper erosion surface. On the basis of these considerations, an approximate age of $54.5-55.5 \mathrm{Ma}$ is proposed for Unit IV. It is not presently possible to determine the nature of the basal contact of Unit IV. A $0.5 \mathrm{Ma}$ hiatus is shown between Unit IV and the basalt series on Figure 11, but the existence of this unconformity is largely conjectural. A duration of $32.3 \mathrm{~m} . \mathrm{y}$. is inferred for the hiatus separating Unit IV and the overlying Neogene sediments.

This interpretation poses major problems for the dinoflagellate biozonation of Manum et al. (this volume). The E. parata- bulata Zone, which is lower Miocene at Site 643 , has a lower Eocene occurrence at Site 642 under these conditions, and the $I$. patulum Zone ranges from the lower Eocene to the lower Miocene at Site 642 (duration $=37$ m.y.). This apparent paradox is resolvable if species occurrences in Sections 104-642D-11X-2 to $-642 \mathrm{D}-13 \mathrm{X}-1$ are ignored. So stipulated, the dinoflagellate biostratigraphy of the overlying interval in Hole 642D appears to be in order, with Ascostomocystis granosa ranging discontinuously down to Section 104-642D-11X-1, E. paratabulata having its first occurrence in Section 104-642D-9X-7 (base of the $E$. paratabulata Zone), and $I$. patulum having a first occurrence in Section 104-642D-5X-6 (base of the I. patulum Zone). If these zonal boundaries were to be readjusted in this manner, then the dinoflagellate biozonation would be in good agreement with the siliceous microfossil biostratigraphies as shown in Figure 10 (backpocket).

\section{Site 643}

Biostratigraphic data pertaining to the Paleogene succession of Site 643 , as well as the chronostratigraphic interpretations based on these data, are compiled in Figure 8. Site 643 is positioned on basement magnetic anomaly 23 (Eldholm, Thiede, Taylor, et al., 1987a), which constrains the maximum age of the oldest sediments to approximately $54-54.5 \mathrm{Ma}$. Only low-diversity assemblages of agglutinated foraminifers have been reported for the pyroclastic muds overlying basement breccia in this hole, with the exception of an isolated occurrence of dinocysts in Section 104-643A-60X-2. The oldest agglutinated foraminifers sampled by Kaminski (1988; Section 104-643A-62X-1) include common Cyclammina placenta, which first occurs in the early Eocene. The distinctive dinocyst flora is characterized as the Rottnestia borussica Zone by Manum et al. (this volume). The nominate species first occurs in zone VI of Site 338 (Fig. 9, backpocket), and ranges to the top of zone IV (Manum, 1976). In Hole 643A, however, this species as well as Achilleodinium biformoides, Diphyes colligerum, and Eatonicysta ursulae are restricted to the $R$. borussica Zone. Early to middle Eocene ages are indicated by this taxa association (Manum et al., this volume).

Dinocysts are relatively persistent in the overlying sandy mudstones, and the oldest dinocyst flora in this succession is the $\mathrm{Ad}$ natosphaeridium vittatum Zone (38 m thick; Sections 104-643A$54 \mathrm{X}-1$ to $-643 \mathrm{~A}-57 \mathrm{X}-7$ ). Manum et al. (this volume) prefer a middle Eocene age for this and younger zones, because unequivocal lower Eocene index taxa are absent. Moreover, both $A$. vittatum, whose range in Hole $643 \mathrm{~A}$ is restricted to the lower $A$. vittatum Zone, and Areosphaeridum diktyoplokus, which first occurs at the base of this zone, are regarded by some authorities as meriting this status. Moreover, the occurrence of Wetzeliella articulata in Hole $643 \mathrm{~A}$ is limited to the base of the $A$. vittatum Zone, and this species ranges no higher than lower Zone VI (lower Eocene) at Site 338. Consequently, it is concluded that the dinocyst evidence can be interpreted as consistent with an early Eocene age for the oldest sediments at Site 643, including the basal pyroclastic muds and the immediately overlying sandy mudstones. This conclusion is supported by the presence of lower Eocene Rhabdammina-Cyclammina Assemblage of agglutinated foraminifers (Kaminski, 1988) in the interval from Section 104-643A-62X-1 to -643A-56X-1. Kaminski (1988) reports the presence of Cyclammina placenta, a species first occurring in the early Eocene, at the base of the RhabdamminaCyclammina Assemblage of Hole 643A.

On the basis of a radiolarian peak occurrence horizon correlated from the Labrador Sea, Kaminski (1988) places Core 104$643 \mathrm{~A}-55 \mathrm{X}$ at the base of the Lutetian Stage (52 Ma according to Berggren et al., 1985). The uppermost lower Eocene to lower middle Eocene Glomospira Assemblage of agglutinated foraminifers occurs in Sections 104-643A-54X-5 to $-643 \mathrm{~A}-50 \mathrm{X}-1$ 


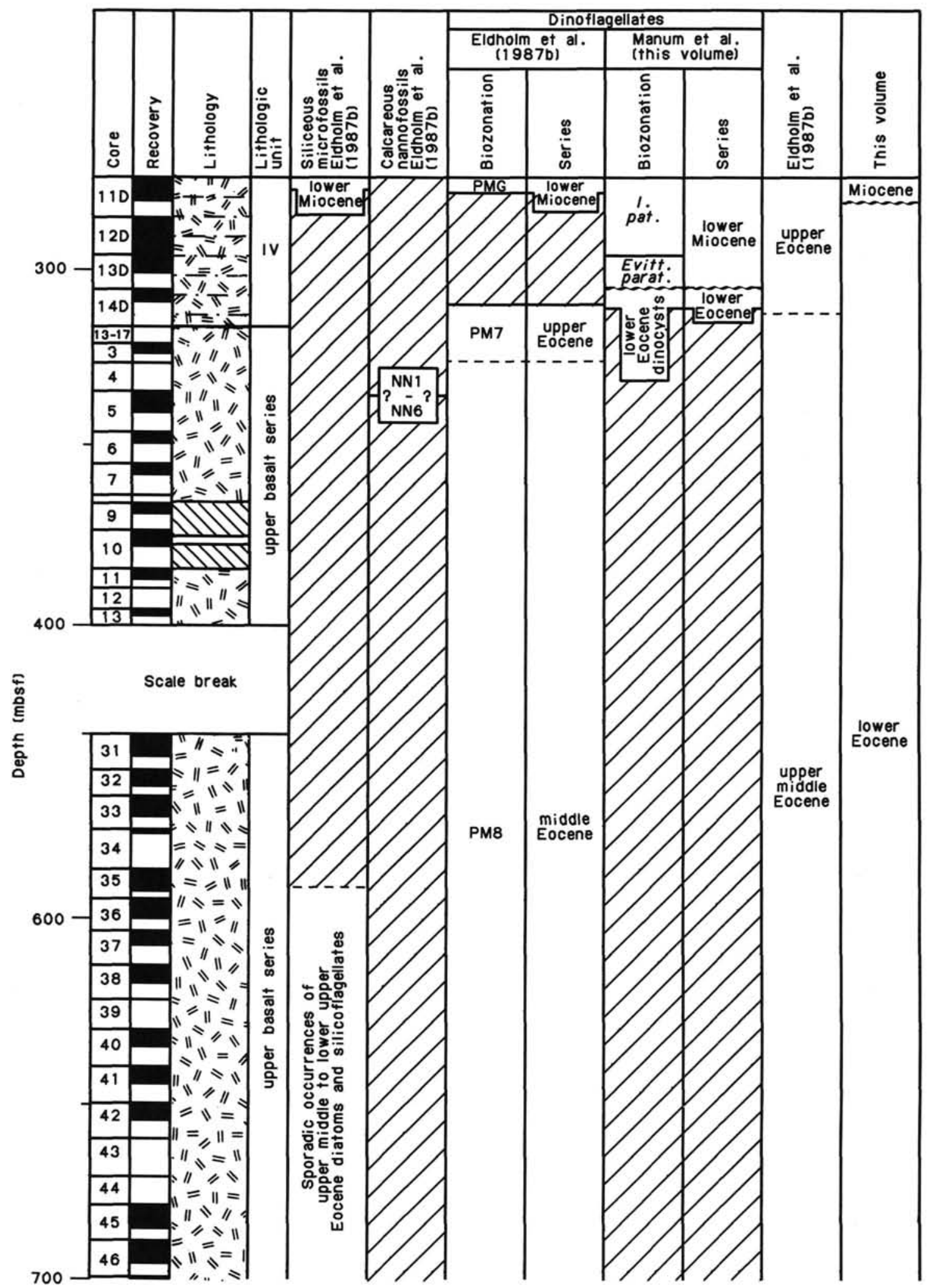

Figure 7. Biostratigraphy and interpreted chronostratigraphy of the Paleogene succession of Site 642, based on results of Eldholm, Thiede, Taylor, et al. (1987b) and papers included in this volume. (Core nomenclature, recovery, and lithologies follow Eldholm, Thiede, Taylor, et al., 1987a.) 


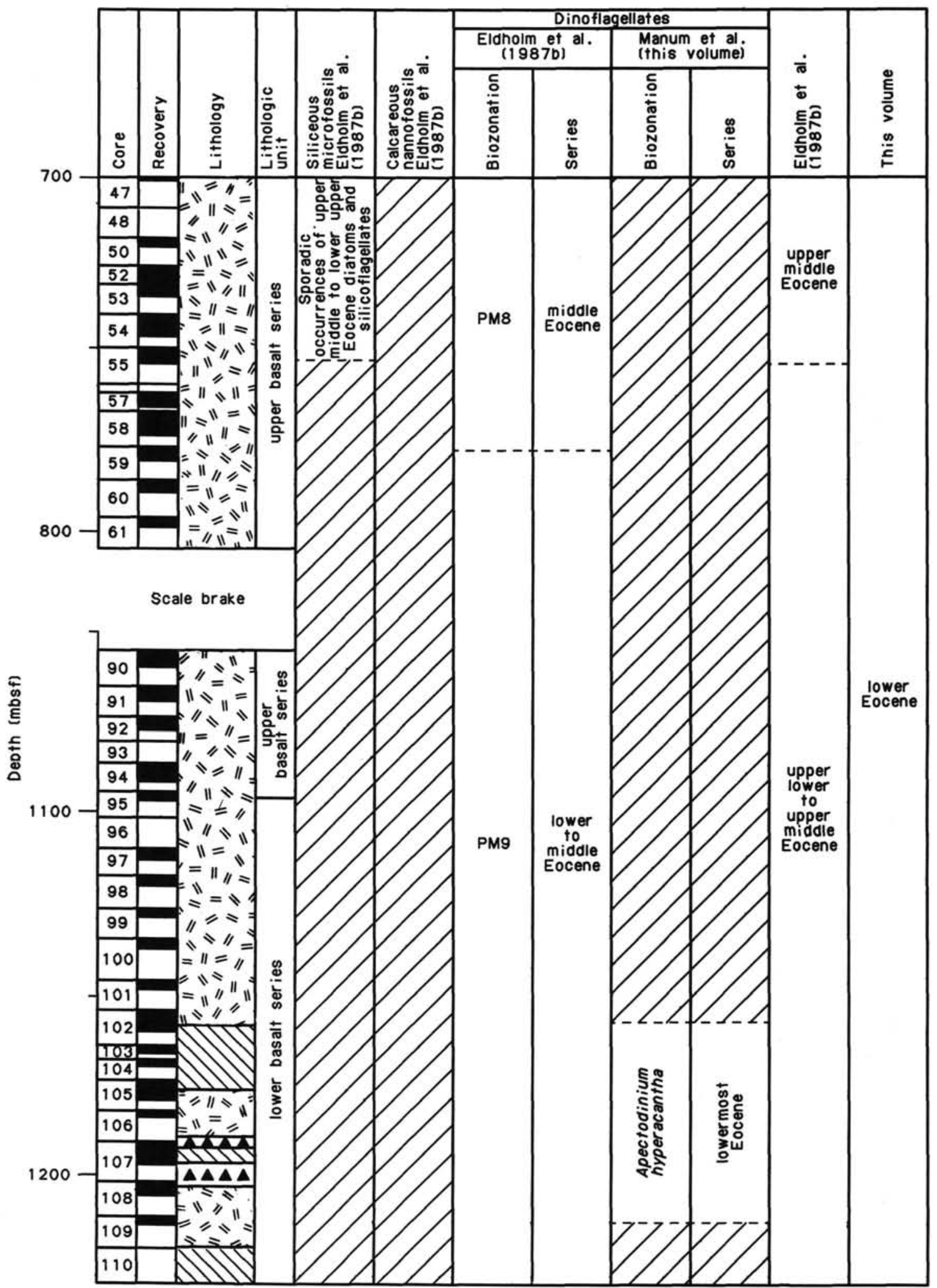

Figure 7 (continued). 


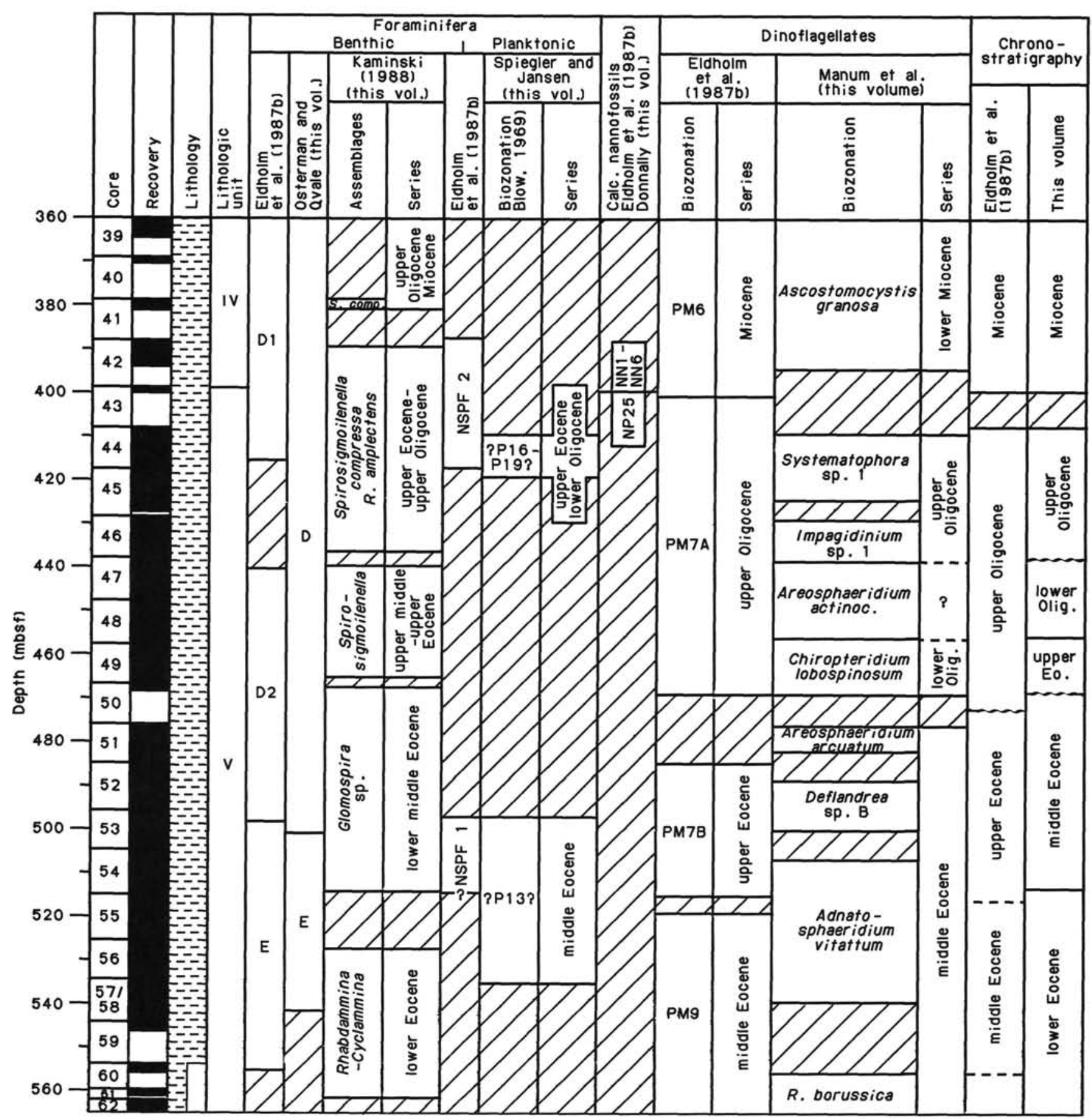

Figure 8. Biostratigraphy and interpreted chronostratigraphy of the Paleogene succession of Site 643, based on results of Eldholm, Thiede, Taylor, et al. (1987b) and papers included in this volume. (Core nomenclature, recovery, and lithologies follow Eldholm, Thiede, Taylor, et al., 1987a.)

(Kaminski, 1988). At Site 647 in the Labrador Sea, this assemblage ranges from mid-calcareous nannofossil zone NP13 to mid Zone CP13b. The Glomospira Assemblage of Site 643 includes Hormosina ovuloides, a species ranging no higher than the lowermost Eocene in the Labrador and North Seas and at localities in Trinidad and Poland (Kaminski, 1988). These sediments are also characterized by dinocyst floras of the Areosphaeridium arcuatum Zone, Deflandrea sp. B Zone, and upper $A$. vittatum Zone, which Manum et al. (this volume) correlate as approximately coeval with dinocyst Zones IV and V of Site 338 (41.0-43.5 Ma, see Leg 38 Correlations section). In fact, there are many dinocyst dissimilarities between these intervals in
Sites 338 and 643. Although present in zone IV and upper Zone V of Site 338, Phthanoperidium amoenum, Leptodinium incompositum, Wetzeliella symmetrica, and Chiropteridium partispinatum, are not reported in Sections 104-643A-54X-5 to -643A-50X-1. The biostratigraphic significance of several of these species is degraded because of taxonomic complexities or environmental sensitivity; however, a judgment is also applicable to Samlandia chlamydophora, which has a very limited occurrence only in Core 104-643A-51X of this sequence. The only dinocyst common to both intervals is $A$. arcuatum, which ranges down to calcareous nannofossil Zone NP14 according to Williams and Bujak (1985). Consequently, we regard this interval in Site 643 
as older than the middle Eocene sequence in Hole 338. The pronounced floral overturn in the middle of the $A$. vittatum Zone (nine dinocyst species first occurrences and nine dinocyst species last occurrences in Core 104-643A-55X) may represent biotic readjustments near the early Eocene/middle Eocene boundary. In the absence of more precise biostratigraphic indications, an age of $50 \mathrm{Ma}$ is arbitrarily assigned to the top of the lowest sequence in Hole 643A. This age is considerably older than the questionable determination of planktonic foraminifer Zone P13, based on badly fragmented specimens of planktonic foraminifers extracted from indurated chalk beds in Cores 104-643A-52X to -643A-56X (Spiegler and Jansen, this volume). A more thorough examination of these chalks is critically needed.

There is disagreement concerning the age of the overlying interval from Sections 104-643A-46X-5 to $-643 \mathrm{~A}-49 \mathrm{X}, \mathrm{CC}$, and it has been necessary to make an arbitrary compromise between conflicting lines of biostratigraphic evidence. Whereas the agglutinated foraminifers in these sediments are correlative with the Eocene of the North Sea, an Oligocene age is indicated on the basis of dinocyst biostratigraphy. Dinocysts such as Distatodinium ellipticum are known to range up to the top of the Eocene elsewhere (Williams and Bujak, 1985), and this species has its last occurrence at the top of Core 104-643A-50X. Chiropteridium lobospinosum and Heteraulacacysta campanula are reported to range no lower than calcareous nannofossil Zone NP23, and these species have first occurrences in Core 104-643A-49X. These considerations and the complete absence of dinocysts regarded as late Eocene markers lead Manum et al. (this volume) to infer a late Eocene hiatus in Core 104-643A-50X and an early Oligocene age for Core 104-643A-49X. Chiropteridium lobospinosum was not recorded in Site 338, however, and $H$. campanula was reported to range down to the base of zone III (upper Oligocene). The biostratigraphic significance of these occurrences is limited by the broad morphological range of both taxa. The lack of comparative sections of equivalent age in the North Sea and Norwegian Sea is a particularly vexing problem in this case.

This interval in Hole $643 \mathrm{~A}$ is also represented by the Spirosigmoilinella sp. Assemblage of agglutinated foraminifers, which includes first occurrences of Budashevaella cf. multicamerata and Dorothia principiensis in Core 104-643A-48X (middle to upper Eocene according to Kaminski, 1988). Additionally, $S$. spectabilis ranges up to $643 \mathrm{~A}-47 \mathrm{X}, \mathrm{CC}$ according to Osterman and Qvale (this volume), and all of the benthic foraminifer specialists who have studied this material agree on the Eocene age of this interval. As a compromise between these conflicting foraminifer and palynologic age interpretations, this short sequence (Sections 104-643A-46X-5 to -643A-49X, CC) is arbitrarily placed in the time range spanning the Eocene/Oligocene boundary (36-38 Ma). The two low-diversity dinocyst zones of this interval, the C. lobospinosum Zone and Areosphaeridium actinocoronatum Zone, are characterized by rapidly shifting floras that may document assemblage readjustments associated with the Eocene/Oligocene boundary.

The overlying interval including Sections 104-643A-43X, CC to $-643 \mathrm{~A}-46 \mathrm{X}-5$ represents the youngest Paleogene sediments at Site 643. Manum et al. (this volume) divide these sediments into two units, the Systematophora sp. 1 Zone and the Impagidinium sp. 1 Zone, which are tentatively correlated with zone III at Site 338. Although present in lower zone III, Chiropteridium dispersum is not recorded in Hole 643A. The association of Impletosphaeridium sp. and Hystrichokolpoma rigaudiae in the absence of $C$. dispersum occurs in Hole 338 only in Section 33823-2 and above. Therefore, we conclude that the Impagidium sp. 1 Zone can be no older than upper zone III and is probably younger than the Oligocene sequence in Hole 338. Because of the absence of Lejeunia taxa in Hole 643A and the apparently gradational biostratigraphic contact at the top of the Systema- tophora sp. 1 Zone (two first occurrences), we conclude that both zones are younger than zone III and that these sediments are conformable with the overlying Miocene section. Consequently, this interval is assigned to the age range $23.5-25.0 \mathrm{Ma}$. The three last occurrences and seven first occurrences at the base of the Impagidium sp. 1 Zone are interpreted as having resulted from the $11 \mathrm{~m} . \mathrm{y}$. hiatus bounding this zone.

Kaminski (1988) combines this interval and the basal Miocene sediments into the Spirosigmoilinella compressa-Reticulophragmium amplectens Assemblage, which is interpreted as a condensed section having a questionable basal age of Eocene. Dinocyst biostratigraphy is preferred for this interval, although the possible Zones P16-P19 assignment based on poorly-preserved planktonic foraminifers extracted from a chalk bed in Core 104-643A-44X by Spiegler and Jansen (this volume) lends weak support for an older age than proposed above.

By convention, the Oligocene/Miocene boundary in high northern latitudes is drawn at the top of calcareous nannofossil zone NP25, which is recognized by a secondary marker (the last occurrence of Discolithina enormis; Martini and Müller, 1985). In Leg 104 sediments, the sole recorded occurrence of this environmentally sensitive species (cold water, neritic) is restricted to one of two closely-spaced samples from Section 104-643A-43X, CC (Donnally, this volume), although the presence of Turrilina alsatica (benthic foraminifers) in Section 104-643A-43X, CC indicates a correlation to the lower Oligocene of the North Sea and Labrador Sea (Kaminski, 1988). The absence of this species in the upper sample may not be biostratigraphically significant, but the inference of a series boundary at this horizon is supported by the presence of Miocene dinocysts in Core 104-643A$42 \mathrm{X}$ (Ascostomocystis granosa Zone).

\section{NEOGENE BIOSTRATIGRAPHY}

Post-Oligocene sections $277.5,400.4$, and $252.8 \mathrm{~m}$ thick were continuously cored at Sites 642,643 , and 644 , respectively. The essentially complete sedimentary record of the past $2.9 \mathrm{~m}$.y. at Site 644 is relatively simple biostratigraphically, the only complication being numerous intervals that are barren of one or more fossil groups. The oldest Neogene sediments recovered at Sites 642 and 643 are interpreted as 21.7 and $23.5 \mathrm{Ma}$ in age, respectively. Although not as controversial as the Paleogene, the biostratigraphy of these successions is nevertheless complicated by the presence of numerous unconformity-bounded sequences and the almost complete absence of lower to middle Miocene calcareous microfossils. The chronostratigraphy of post-middle Miocene sedimentation at both sites is comparatively straightforward, partly as a result of better quality polarity records. Although not consistently present, calcareous microfossils provide adequate local and inter-regional correlation points for confident biostratigraphy in these younger intervals. Ages to the nearest $0.1 \mathrm{Ma}$ assigned to these cores are regarded as reasonably accurate. The lower to middle Miocene biostratigraphies of Sites 642 and 643 pose greater problems, because of obscure polarity records and few firmly-grounded correlation points. Core ages greater than $10.2 \mathrm{Ma}$ are proposed with considerable caution. Although Leg 104 chronostratigraphy is somewhat controversial (as will be explained in the following discussion), the sediment ages indicated in this synthesis are assumed, for the sake of internal consistency among the various contributions to this volume, to be correct.

An interpretation of the Neogene chronostratigraphy of Leg 104 sediments is presented in two summary diagrams (Figs. 910) and in Table 3. Figures 9 and 10 (backpocket) are drawn at the same vertical scale to facilitate comparison, and the two figures can be regarded as a single chart. The chronology of these successions, the criteria used for correlation, and numerous comparative schemes are illustrated in Figure 9. All of the Neo- 
Table 3. Characteristics of the Norwegian Sea Neogene synthemic units proposed in this paper. B, CN, BF, PF, D, E + A, R, and S refer to Bolboforma, calcareous nannofossils, benthic foraminifers, planktonic foraminifers, dinoflagellates, ebridians + actiniscidians, radiolarians, and silicoflagellates. FO, first occurrence; LO, last occurrence.

\begin{tabular}{|c|c|c|c|c|c|c|c|c|c|c|}
\hline $\begin{array}{l}\text { Synthem/ } \\
\text { Subsynthem }\end{array}$ & Interval & $\begin{array}{c}\text { Depth range } \\
\text { (mbsf) }\end{array}$ & $\begin{array}{l}\text { Thickness } \\
\text { (m) }\end{array}$ & $\begin{array}{l}\text { Age } \\
\text { range } \\
\text { (Ma) }\end{array}$ & $\begin{array}{l}\text { Duration } \\
\text { (m.y.) }\end{array}$ & $\begin{array}{l}\text { Basal } \\
\text { hiatus } \\
\text { (m.y.) }\end{array}$ & $\begin{array}{l}\text { Lithologic } \\
\text { unit }\end{array}$ & & Biozones & $\begin{array}{l}\text { Age-diagnostic species } \\
\text { and correlation criteria }\end{array}$ \\
\hline NSN 2.4 & $\begin{array}{l}104-642 \mathrm{~B}-1 \mathrm{H}-1 \text { to }-8 \mathrm{H}, \mathrm{CC} \\
104-642 \mathrm{C}-1 \mathrm{H}-1 \text { to }-8 \mathrm{H}-1 \\
104-643 \mathrm{~A}-1 \mathrm{H}-1 \text { to }-6 \mathrm{H}-5 \\
104-644 \mathrm{~A}-1 \mathrm{H}-1 \text { to }-34 \mathrm{H}, \mathrm{CC}\end{array}$ & $\begin{array}{l}0-66.4 \\
0-58.6 \\
0-51.5 \\
0-252.8\end{array}$ & $\begin{array}{r}66.4 \\
58.6 \\
51.5 \\
252.8\end{array}$ & $\begin{array}{l}0-2.6 \\
0-2.6 \\
0-2.6 \\
0-2.9\end{array}$ & $\begin{array}{l}2.6 \\
2.6 \\
2.6 \\
2.9\end{array}$ & $\begin{array}{r}0.5 \\
0.5 \\
0.6 \\
-\end{array}$ & $\begin{array}{c}1 \\
1 \\
1 \\
1-111\end{array}$ & $\begin{array}{l}\text { D } \\
\text { E\&A } \\
\text { R } \\
S\end{array}$ & 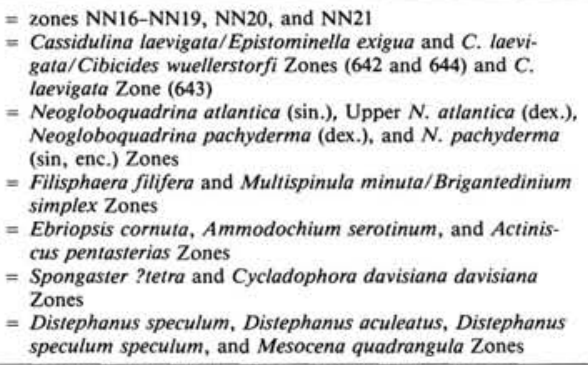 & 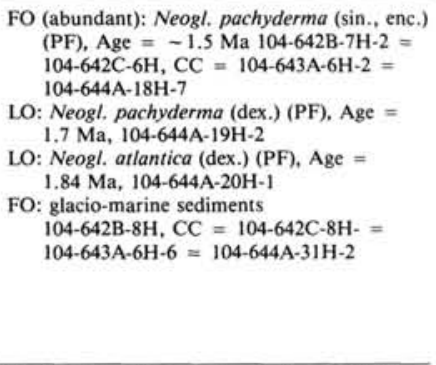 \\
\hline $\begin{array}{l}\text { NSN } 2.21 \\
\text { NSN } 2.3\end{array}$ & $\begin{array}{l}104-642 \mathrm{~B}-9 \mathrm{H}-1 \text { to }-15 \mathrm{H}-1 \\
104-642 \mathrm{C}-8 \mathrm{H}-2 \text { to }-15 \mathrm{H}, \mathrm{CC}\end{array}$ & $\begin{array}{l}66.4-125.0 \\
58.6-120.5\end{array}$ & $\begin{array}{l}58.6 \\
61.9\end{array}$ & $\begin{array}{l}3.1-6.1 \\
3.1-6.1\end{array}$ & $\begin{array}{l}3.0 \\
3.0\end{array}$ & $\begin{array}{l}1.5 \\
1.5\end{array}$ & $\begin{array}{l}\text { IIA-up. IIC } \\
\text { IIA-up. IIC }\end{array}$ & $\begin{array}{l}\mathrm{B} \\
\mathrm{CN} \\
\mathrm{BF} \\
\mathrm{PF} \\
\mathrm{D} \\
\mathrm{E} \& \mathrm{~A} \\
\mathrm{R}\end{array}$ & 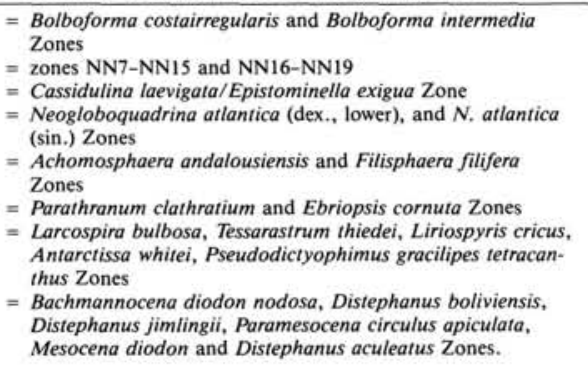 & 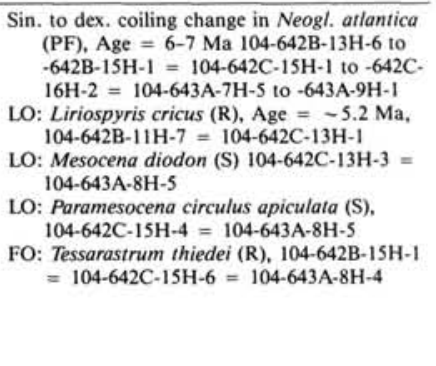 \\
\hline $\begin{array}{l}\text { NSN } 2.3 \\
\text { NSN } 2.2\end{array}$ & $\begin{array}{l}104-643 \mathrm{~A}-6 \mathrm{H}-5 \text { to }-7 \mathrm{H}-\mathrm{CC} \\
104-643 \mathrm{~A}-8 \mathrm{H}-1 \text { to }-8 \mathrm{H}-5\end{array}$ & $\begin{array}{l}51.5-62.3 \\
62.3-69.3\end{array}$ & $\begin{array}{r}10.8 \\
6.0\end{array}$ & $\begin{array}{l}3.2-4.2 \\
5.6-6.0\end{array}$ & $\begin{array}{l}1.0 \\
0.4\end{array}$ & $\begin{array}{l}1.3 \\
0.9\end{array}$ & $\begin{array}{l}\text { up. IIa } \\
\text { low IIA-up. IIB }\end{array}$ & & & \\
\hline NSN 2.1 & $\begin{array}{l}104-642 \mathrm{~B}-15 \mathrm{H}-2 \text { to }-19 \mathrm{H}-2 \\
104-642 \mathrm{C}-16 \mathrm{H}-1 \text { to }-19 \mathrm{H}-6 \\
104-643 \mathrm{~A}-8 \mathrm{H}-5 \text { to }-11 \mathrm{H}, \mathrm{CC}\end{array}$ & $\begin{array}{r}125.0-160.3 \\
120.5-158.0 \\
69.3-100.3\end{array}$ & $\begin{array}{l}35.3 \\
37.5 \\
31.0\end{array}$ & $\begin{array}{l}7.6-10.2 \\
7.6-10.2 \\
6.9-8.8\end{array}$ & $\begin{array}{l}2.6 \\
2.6 \\
1.9\end{array}$ & $\begin{array}{l}3.2 \\
3.2 \\
4.9\end{array}$ & $\begin{array}{l}\text { IIC-up. III } \\
\text { IIC-up. III } \\
\text { low IIB-IIC }\end{array}$ & $\begin{array}{l}\mathrm{CN} \\
\mathrm{BF} \\
\mathrm{PF} \\
\mathrm{D} \\
\mathrm{E} \& A \\
\mathrm{R}\end{array}$ & 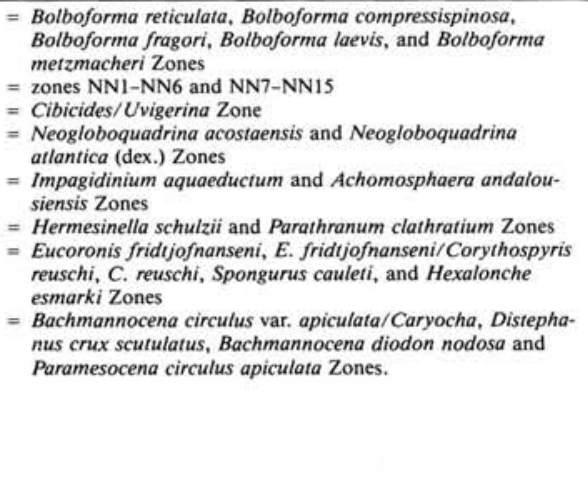 & 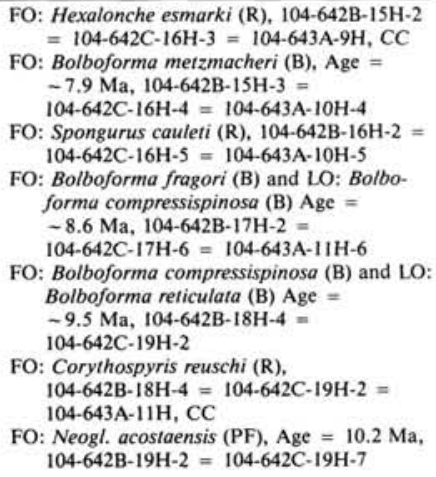 \\
\hline
\end{tabular}




\begin{tabular}{|c|c|c|c|c|c|c|c|c|c|c|}
\hline NSN 1.6 & $\begin{array}{l}104-642 \mathrm{~B}-19 \mathrm{H}-2 \text { to }-19 \mathrm{H}-5 \\
104-642 \mathrm{C}-19 \mathrm{H}-6 \text { to }-20 \mathrm{H}-2 \\
104-643 \mathrm{~A}-12 \mathrm{H}-1 \text { to }-12 \mathrm{H}-2\end{array}$ & $\begin{array}{l}160.3-164.7 \\
158.0-161.0 \\
100.3-102.6\end{array}$ & $\begin{array}{l}4.3 \\
3.0 \\
2.3\end{array}$ & $\begin{array}{l}\sim 13.4-13.6 \\
\sim 13.4-13.6 \\
\sim 13.7\end{array}$ & $\begin{array}{l}-0.2 \\
-0.2 \\
<0.1\end{array}$ & $\begin{array}{l}-0.3 \\
-0.3 \\
-0.4\end{array}$ & $\begin{array}{l}\text { III } \\
\text { III } \\
\text { III }\end{array}$ & $\begin{array}{l}\mathrm{B} \\
\mathrm{CN} \\
\mathrm{BF} \\
\mathrm{PF} \\
\mathrm{D} \\
\mathrm{E} \& \mathrm{~A} \\
\mathrm{R} \\
\mathrm{S}\end{array}$ & $\begin{array}{l}=\text { Bolboforma reticulata } \\
=\text { zone NN1-NN6 } \\
=\text { Cibicides/Uvigerina Zone } \\
=\text { Neogloboquadrina mayeri Zone } \\
=\text { Achomosphaera andalousiensis Zone } \\
=\text { Hermesinella schulzii Zone } \\
=\text { Clathrospyris vogiti and Eucoronis fridtiofnanseni Zone } \\
=\text { Bachmannocena circulus var. apiculata/Caryocha, and } \\
\text { Upper Corbisema triacantha Zones. }\end{array}$ & $\begin{array}{l}\text { LO: Cannopilus depressus }(\mathrm{S}) \mathrm{Age}=\mathrm{NN} 6 \\
104-642 \mathrm{C}-19 \mathrm{H}-5 \\
\text { F: Clathrospyris vogti }(\mathrm{R}) 104-643 \mathrm{~A}-12 \mathrm{H}-2\end{array}$ \\
\hline NSN 1.5 & $\begin{array}{l}104-642 \mathrm{~B}-19 \mathrm{H}-6 \text { to }-22 \mathrm{H}-5 \\
104-642 \mathrm{C}-20 \mathrm{H}-3 \text { to }-24 \mathrm{H}, \mathrm{CC} \\
104-642 \mathrm{D}-2 \mathrm{X}-1 \text { to }-3 \mathrm{X}-2 \\
104-643 \mathrm{~A}-12 \mathrm{H}-3 \text { to }-13 \mathrm{H}-3\end{array}$ & $\begin{array}{l}164.7-193.0 \\
161.0-194.2 \\
189.9-196.2 \\
102.9-114.2\end{array}$ & $\begin{array}{r}28.3 \\
33.2 \\
6.3 \\
11.3\end{array}$ & $\begin{array}{l}-13.9-14.9 \\
\sim 13.9-14.9 \\
-14.8-14.9 \\
\sim 14.1-14.5\end{array}$ & $\begin{array}{l}-1.0 \\
-1.0 \\
-0.1 \\
-0.4\end{array}$ & $\begin{array}{l}-0.5 \\
-0.5 \\
-0.5 \\
-0.3\end{array}$ & $\begin{array}{l}\text { III } \\
\text { III } \\
\text { III } \\
\text { III }\end{array}$ & $\begin{array}{l}\text { BF } \\
D \\
\text { E\&A } \\
\text { R } \\
\text { S }\end{array}$ & $\begin{array}{l}=\text { Spirosigmoilinella }(643 \mathrm{~A}) \text { and Martinottiella communis (642) } \\
\text { Zones } \\
=\text { Labyrinthodinium truncatum and Impagidinium aquaeduc- } \\
\text { tum Zones } \\
=\text { Spongebria miocenica and Hermesinella schulzii Zones } \\
=\text { Ceratocyrtis ampullacea Subzone and Pseudodictyophimus } \\
\text { horrida Zone } \\
=\text { Distephanus speculum hemisphaericus, Caryocha ernestinae } \\
\text { and lower Corbisema triacantha Zones. }\end{array}$ & 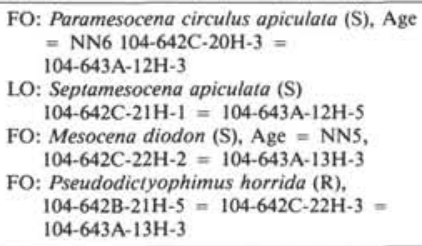 \\
\hline NSN 1.4 & $104-643 \mathrm{~A}-13 \mathrm{H}-4$ to $-15 \mathrm{H}-4$ & $114.2-134.4$ & 20.2 & $-14.8-15.3$ & -0.5 & -0.3 & III & $\begin{array}{l}\text { BF } \\
\text { D } \\
\text { R } \\
S\end{array}$ & $\begin{array}{l}=\text { Spirosigmoilinella Zone } \\
=\text { Labyrinthodinium truncatum Zone } \\
=\text { Ceratocyrtis broeggeri Zone and Ceratocyrtis kladaros } \\
\text { Subzone } \\
=\text { Distephanus speculum hemisphaericus }\end{array}$ & $\begin{array}{l}\text { FO: Cyrtocapsella kladaros (R), } \\
\text { 104-643A -13H, CC } \\
\text { FO: Spongebria miocenica (E), } \\
\text { 104-6433-15H-4 }\end{array}$ \\
\hline NSN 1.3 & $\begin{array}{l}104-642 \mathrm{~B}-22 \mathrm{H}-6 \text { to }-23 \mathrm{H}-3 \\
104-642 \mathrm{C}-24 \mathrm{H}-3 \text { to }-24 \mathrm{H}, \mathrm{CC} \\
104-642 \mathrm{D}-2 \mathrm{X}-6 \text { to }-3 \mathrm{X}-2\end{array}$ & $\begin{array}{l}193.0-199.8 \\
194.2-199.6 \\
196.2-201.4\end{array}$ & $\begin{array}{l}6.8 \\
5.4 \\
5.2\end{array}$ & $\begin{array}{l}\sim 15.4-15.7 \\
-15.4-15.7 \\
\sim 15.4-15.7\end{array}$ & $\begin{array}{l}-0.3 \\
-0.3 \\
-0.3\end{array}$ & $\begin{array}{l}-1.5 \\
-1.5\end{array}$ & $\begin{array}{l}\text { III } \\
\text { III } \\
\text { III }\end{array}$ & $\begin{array}{l}\text { BF } \\
\text { D } \\
\text { E } \\
\text { R } \\
\text { S }\end{array}$ & $\begin{array}{l}=\text { Spirosigmoilinella and Martinottiella communis Zones } \\
=\text { Emsiandia spiridoides Zone } \\
=\text { Spongebria miocenica Zone } \\
=\text { Cyrtocapsella eldholmi and Ceratocyrtis broeggeri Zone } \\
=\text { Distephanus speculum hemisphaericus and lower Corbisema } \\
\text { triacantha Zones }\end{array}$ & $\begin{array}{l}\text { FO: Ceratocyrtis stroermeri }(\mathrm{R}), \\
\text { 104-642B-22H, CC }=104-642 \mathrm{C}-24 \mathrm{H}-4= \\
\text { 104-642D-2X-6 }=104-643 \mathrm{~A}-15 \mathrm{H}-4 \\
\text { FO: Cyrtocapsella eldholmi (R), } \\
\text { 104-642B-23H-3 }=104-642 \mathrm{C}-24, \mathrm{CC}= \\
\text { 104-642D-3X-2 }\end{array}$ \\
\hline NSN 1.2 & $\begin{array}{l}\text { 104-642B-23H, CC to }-25 \mathrm{H}, \mathrm{CC} \\
104-642 \mathrm{D}-3 \mathrm{X}-3 \text { to }-8 \mathrm{X}-3 \\
104-643 \mathrm{~A}-15 \mathrm{H}-5 \text { to }-29 \mathrm{X}, \mathrm{CC}\end{array}$ & $\begin{array}{l}199.8-221.1 \\
201.4-251.0 \\
134.4-273.8\end{array}$ & $\begin{array}{r}21.3 \\
41.8 \\
139.4\end{array}$ & $\begin{array}{l}\sim 17.2-18.1 \\
\sim 17.2-19.3 \\
\sim 15.6-19.0\end{array}$ & $\begin{array}{l}-0.9 \\
-2.1 \\
-3.6\end{array}$ & $\begin{array}{r}\overline{-0.9} \\
\sim 0.7\end{array}$ & $\begin{array}{l}\text { III } \\
\text { III } \\
\text { III }\end{array}$ & $\begin{array}{l}\text { BF } \\
\text { D } \\
\text { A } \\
\text { R }\end{array}$ & $\begin{array}{l}=\text { Spirosigmoilinella Zone } \\
=\text { Impagidinium patulum and Emslandia spiridoides Zones } \\
=\text { Foliactiniscus folia and Hermesinium adriaticum Zones } \\
=\text { Gondwanaria japonica kiaeri, Clathrospyris sandellae, } \\
\text { Corythospyris jubata sverdrupi, Pseudodictyophimus } \\
\text { amundseni, Spongotrochus vitabilis, Cycladophora davisiana } \\
\text { cornutoides, and Ceratocyrtis manumi Zones } \\
=\text { Naviculopsis quadrata, Naviculopsis ponticula, Distephanus } \\
\text { speculum hemisphaericus, and lower Corbisema triacantha } \\
\text { Zones }\end{array}$ & 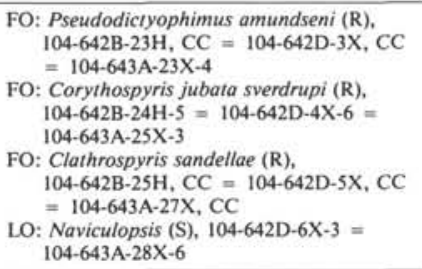 \\
\hline NSN 1.1 & $\begin{array}{l}104-642 D-8 X-4 \text { to }-11 X-1 \\
104-643 \mathrm{~A}-30 \mathrm{X}-1 \text { to }-42 \mathrm{X}, \mathrm{CC}\end{array}$ & $\begin{array}{l}251.0-277.5 \\
273.8-400.4\end{array}$ & $\begin{array}{r}26.5 \\
126.6\end{array}$ & $\begin{array}{l}-20.4-21.7 \\
-19.7-23.5\end{array}$ & $\begin{array}{l}-1.3 \\
-3.8\end{array}$ & -32.0 & $\begin{array}{l}\text { III } \\
\text { IIII }\end{array}$ & $\begin{array}{l}\text { BF } \\
\text { D } \\
\text { A } \\
\text { R } \\
\text { S }\end{array}$ & $\begin{array}{l}=\text { Haplophragmoides walteri and Spirosigmoilinella Zones } \\
=\text { Ascostomocystis granosa, Evittosphaerula paratabulata and } \\
\text { Impagidinium patulum Zones } \\
=\text { Foliactiniscus atlanticus and Foliactiniscus folia Zones } \\
=\text { Eucyrtidium saccoi, Actinomma henningsmoeni, and } \\
\text { Gondwanaria japonica kieari Zones } \\
=\text { Naviculopsis lata and Naviculopsis navicula Z Znes }\end{array}$ & $\begin{array}{l}\text { FO: Actinomma henningsmoeni (R), Age }= \\
-22 \text { Ma, 104-642D-11X-1 } \\
\text { LO: Naviculopsis lata }(\mathrm{S}), \mathrm{Age}=-23 \mathrm{Ma}, \\
\text { 104-642D-8X-5 }\end{array}$ \\
\hline
\end{tabular}


gene biozonations proposed for the microfossil groups treated in Eldholm, Thiede, Taylor, et al. (1987b) and in this volume are compiled in Figure 10.

The post-Oligocene sediments of Holes $642 \mathrm{~B}, 642 \mathrm{C}, 642 \mathrm{D}$, $643 \mathrm{~A}$, and $644 \mathrm{~A}$ are plotted against time in the center columns of Figure 9 (backpocket). Information concerning the sediments recovered in each hole are presented in sets of seven columns. Chron assignments for the polarity records of the left-hand columns are not specifically identified, to avoid further confusion with the alternative interpretations of some intervals as proposed by Bleil (this volume). Core statistics and lithologic data have been taken from Eldholm, Thiede, Taylor, et al. (1987b). The arrows of the right-hand columns point to the base of each core and record its depth (mbsf) and age (nearest $0.1 \mathrm{Ma}$ ). The hole data columns are bordered on the left by Leg 104 hiatus/synthem nomenclature, standard magnetostratigraphy (from Berggren et al., 1985), and the sequence stratigraphic curve of Haq, Hardenbol, and Vail (1987). These columns are in turn flanked to the left by five paleoenvironmental curves for Sites 642 and 643. Burial history curves form the extreme left margin of Figure 9 (backpocket), and the right margin consists of the biostratigraphic events used for correlation and two standard calcareous microfossil biozonations (from Berggren et al., 1985) for convenient reference.

A tentative system of ten Norwegian Sea Neogene synthemic units (NSN 1.1 to NSN 2.4) is proposed here for Leg 104 sequences. The intervening hiatuses are designated by the bounding synthems/subsynthems. The major middle Miocene hiatus divides the successions of both Sites 642 and 643 into two major synthems (NSN 1.0 and NSN 2.0), which differ significantly in sediment character and thus in mode of correlation. The first occurrence of the planktonic foraminifer Neogloboquadrina acostaensis (10.2 Ma) marks the base of Synthem NSN 2.0 at Site 642 (Spiegler and Jansen, this volume). The chronology of Synthem NSN 2.0 cores at both sites is based almost exclusively on biostratigraphy and magnetostratigraphy. The principal biostratigraphic inconsistency is the last occurrences of the calcareous nannofossil Cyclicargolithus abisectus, and Cyclicargolithus floridanus, above the $N$. acostaensis datum in Hole 642B (but below this datum in Hole 642C; see Donnally, this volume). Because these species are regarded as having extinction levels at the top of zone NN6 (approximately 13.4 Ma according to Berggren et al., 1985), the location of this event above the $N$. acostaensis datum is anomalous. This inverted sequence is explained as resulting from sediment reworking, which was also responsible for the anomalously young last occurrence of Neogloboquadrina mayeri at Hole $642 \mathrm{C}$. The basal sediments of Subsynthem NSN 2.1 at Site 642 are regarded as a lag deposit including minor components of the fossil assemblages in Subsynthem NSN 1.6. The top of Synthem NSN 1.0 is taken as $13.4 \mathrm{Ma}$, based on the inferred actual extinction levels of C. floridanus and $C$. abisectus (calcareous nannofossils).

This interpretation is contested by Goll and Bjørklund (this volume), who find no evidence of mixed radiolarian faunas in Subsynthem NSN 2.1 and question the age of Subsynthem NSN 1.6. According to these authors, Subsynthem NSN 1.6 is younger than shown in Figure 9 (backpocket) and may represent the base of Subsynthem NSN 2.1. Although only a thin sliver of sediment is involved in this controversy $(4.3 \mathrm{~m}$ in Hole $642 \mathrm{~B}$ and $3.0 \mathrm{~m}$ in Hole $642 \mathrm{C}$ ), the age of Subsynthem NSN 1.6 at Site 642 is nevertheless important because it represents the oldest record of significant Neogene calcite preservation on the Vøring Plateau. As shown in Figure 9, the fall of the lysocline associated with the onset of calcite preservation occurred at 13.6-13.9 $\mathrm{Ma}$, whereas Goll and Bjørklund suggest a younger age, possibly as young as $10.4 \mathrm{Ma}$.
Interpretation of Synthem NSN 1.0 chronostratigraphy at Sites 642 and 643 is tenuous and will doubtless require further investigation. The disposition of NSN 1.0 sediments in Figure 9 (backpocket) represents a difficult compromise between magnetostratigraphy and the loosely constrained tie points. The general procedures used to correlate Synthem NSN 1.0 sediments are outlined in the section on Paleomagnetic Stratigraphy and Sedimentation Rates, and specific criteria are treated in the following discussion.

\section{Subsynthem NSN 1.1}

This unit is regarded as completely developed at Site 643, where it consists of $126.6 \mathrm{~m}$ of compaction-laminated mudstones poorly recovered in 13 cores, and there are no magnetic polarity records. Although sparse siliceous microfossils occur in the upper sediments, biostratigraphic control is based almost exclusively on benthic foraminifers and dinoflagellates. Goll and Bjorklund (this volume) report a questionable occurrence of the Gondwanaria japonica kiaeri Zone (radiolarians) in the top of Core 104-643A-30X, but these specimens may have been mechanically displaced from the Subsynthem NSN 1.2 sediments of Core 104-643A-29X. Subsynthem NSN 1.1 is regarded as conformable with the underlying Oligocene mudstones in the absence of contravening biostratigraphic evidence. Kaminski (1988) refers the agglutinated benthic foraminifers of Core 104$643 \mathrm{~A}-41 \mathrm{X}$ to the Spirosigmoilinella compressa-Reticulophragmium amplectens Assemblage, and those of Core 104-643A$41 \mathrm{X}$ to the Spirosigmoilinella compressa Assemblage. The presence of Karreriella siphonella, Ammodiscus cretaceus, and Cyclammina acutidorsata in the latter assemblage suggests a correlation with Site 345 at a depth no higher than Section 38-345-12, CC. Such an inferred age (30-31 Ma, according to Fig. 9, backpocket) is at variance with the early Miocene age for Subsynthem NSN 1.1 adopted for this synthesis.

Because none of the fossils observed in this sequence presently have chronostratigraphic correlation potential, the constant sedimentation rate $(33.3 \mathrm{~m} / \mathrm{m} . \mathrm{y}$.) applied to this interval has been adjusted only such that the first occurrence of Evittosphaerula paratabulata is approximately coeval with this event in Hole 642D. A $0.7 \mathrm{Ma}$ hiatus is suggested for the top of Subsynthem NSN 1.1 at Site 643, based on this constant sedimentation rate. The presence of such a hiatus in the interval including Cores 104-643A-28X to -643A-31X (upper Evittosphaerula paratabulata Zone) is supported by dinoflagellate biostratigraphy (Manum et al., this volume). A discontinuity in this interval is suggested by eleven dinocyst first occurrences and nine last occurrences, although it is not possible to discriminate which among these range terminations were environmentally induced, from those having chronostratigraphic significance. No well-established chronostratigraphic marker taxa have been recognized in upper Subsynthem 1.1 to confirm such a hiatus, and sedimentation may have been continuous across this marked facies transition, which is not clearly differentiated in the benthic foraminifer assemblages reported by Osterman and Qvale (this volume). An explanation for such a conformable contact is proposed in the Discussion section.

The questionable hiatus bounding the top of Subsynthem NSN 1.1 in Hole 643A is thought to be the equivalent of a more biostratigraphically distinguishable hiatus in Core 104-642D-8X, which is represented by changes in both the radiolarian and silicoflagellate assemblages. The underlying $26.5 \mathrm{~m}$ of muddy siliceous ooze constitute the only Subsynthem NSN 1.1 sediments recovered at Site 642. Ciesielski, Hasson, and Turner (this volume) propose a correlation of Cores 104-642D-9X and -642D-10X to lower Chron C6B or upper Chron C6C. Goll and Bjørklund (this volume) suggest an approximate age of $22 \mathrm{Ma}$ for the $A$. hen- 
ningsmoeni Zone. The age here assigned to Subsynthem NSN 1.1 is taken as a compromise between these similar indications and the polarity record.

Manum et al. (this volume) regard Subsynthem NSN 1.1 in Hole $642 \mathrm{D}$ as no older than Core 104-643A-27X, on the basis of the recognition of the Impagidinium patulum Zone (dinoflagellates). In fact, I. patulum (the basal boundary criterion of the nominate zone) is not recorded for Subsynthem NSN 1.1. Occurrences of this species in Hole 642D are restricted to Subsynthem NSN 1.2 (where they are here regarded as in place) and Core 104-642D-12X, which is here interpreted as Eocene age (see the Paleogene Biostratigraphy section for a more detailed discussion of this problem). The dinoflagellate biostratigraphy of Hole 642D is partly obscured by flora reworking, and maximum ages are more reliable under these conditions. Correlations with the upper Ascostomocystis granosa Zone and lower Evittosphaerula paratabula Zone of Site 643 are preferred in this synthesis for Subsynthem NSN 1.1 at Site 642.

\section{Subsynthem NSN 1.2}

At Site 643, Subsynthem NSN 1.2 consists of $139.4 \mathrm{~m}$ of siliceous ooze that are interpreted as representing a continuous record of sedimentation across the lower Miocene-middle Miocene boundary, although biostratigraphic control is very limited. Goll and Bjørklund (this volume) report radiolarians regarded as originating approximately $19 \mathrm{Ma}$ in Core 104-643A-29X, which is in agreement with the Naviculopsis datum. Additionally, ages of $16.4,16.8,17.6$, and $17.9 \mathrm{Ma}$ are reported by Ciesielski and Case (this volume) for first occurrences of Cestodiscus peplum and Actinocyclus ingens and last occurrences of Triceratium pileus and Thalassiosira spinosa, respectively, in Sections 104$643 \mathrm{~A}-15 \mathrm{H}-4$ to $-643 \mathrm{~A}-29 \mathrm{X}-5$. These ages are in rough accord with core ages shown in Figure 9. However, the age of the top of Subsynthem NSN 1.2 at Site 643 is poorly constrained, and the constant sedimentation rate derived for this sequence as correlated in Figure 9 (backpocket) is very high $(39.7 \mathrm{~m} / \mathrm{m} . \mathrm{y}$., postcompaction). Further study is necessary to obtain adequate biostratigraphic control for this sequence.

The calcareous layer in Core 104-643A-16H, which bears Neogloboquadrina nana/N.continuosa (planktonic foraminifers) and Zones NN1-NN6 calcareous nannofossils, is approximately correlative with the Globigerinoides trilobus-bearing bed in Core 104-642B-23H, although the latter occurrence is referred to Subsynthem NSN 1.3.

Subsynthem 1.2 was also penetrated in Holes 642B and 642D, where the sequence is coeval only with the lower half of Subsynthem NSN 1.2 at Site 643. The Spongotrochus vitabilis, Cycladophora davisiana cornutoides, and Ceratocyrtis manumi Zones (radiolarians) are not present at Site 642. Subsynthem 1.2 is interpreted as broken by a short hiatus (ca. 0.3 m.y.) between Cores 104-642D-5X and -642D-6X on the basis of the absence of the lower Cladrospyris sandellae Zone (radiolarians).

\section{Subsynthem NSN 1.3}

Subsynthem 1.3 was recovered only at Site 642 , where it is present in Holes 642B, 642C, and 642D. This sequence (5.2$6.8 \mathrm{~m}$ thick) is recognized as a unique Subsynthem on the basis of the Cyrtocapsella eldholmi Zone (radiolarian), which occurs at Site 642 but is absent at Site 643. Smalley, Qvale, and Qvale (this volume) report isotope ages of $17.0 \pm 1.0 \mathrm{Ma}$ and $16.8 \pm$ 0.6 Ma for Sections 104-642B-22H-6 and -643B-23H-1, respectively. These ages are 1.6 and $1.3 \mathrm{~m} . \mathrm{y}$. older than those indicated in Figure 9. Presently, there are no other biostratigraphic indicators of its age. Subsynthem NSN 1.2 is shown in Figure 9 (backpocket) as almost completely filling a hiatus in Core 104$643 \mathrm{~A}-15 \mathrm{H}$. The $0.1-\mathrm{m} . \mathrm{y}$. overlap with the top of Subsynthem NSN 1.2 of Site 643 may be exaggerated or nonexistent. The hi- atus in Core 104-643A-15H may be significantly larger than indicated in Figure 9, and Subsynthem NSN 1.3 at Site 642 may represent only a small portion of its total duration.

\section{Subsynthem NSN 1.4}

This sequence occurs only at Site 643 . The relative biostratigraphic position of Subsynthem NSN 1.4 in Figure 9 (backpocket) is based primarily on the Ceratocyrtis broeggeri Zone (radiolarian), which is $13.2 \mathrm{~m}$ thick at Site 643 and only $1.5 \mathrm{~m}$ thick at Site 642 . The indicated $0.1 \mathrm{~m} . \mathrm{y}$. overlap with the base of Subsynthem NSN 1.5 at Site 642 may be exaggerated or incorrect. Ciesielski and Case (this volume) report ages of 13.9 to 15.0 Ma for the first occurrences of Denticulopsis hustedti (main and isolate), D. punctatum hustedti and D. hyalina and the last occurrence of Cestodiscus peplum between Sections $104-643 \mathrm{~A}-13 \mathrm{H}-1$ and $-643 \mathrm{~A}-14 \mathrm{H}-6$. The maximum of this age range is closer to the core ages shown on Figure 9.

\section{Subsynthem NSN 1.5}

Sequences of unequal length and duration at Sites 642 and 643 are referred to Subsynthem NSN 1.5. Ciesielski and Case (this volume) report first occurrences of Denticulopsis hustedti, D. punctatum hustedii and D. hyalina (13.7-15.0 Ma) in Sections $104-642 \mathrm{C}-21 \mathrm{H}-5$ to $-642 \mathrm{C}-23 \mathrm{H}-2$ (also reported for Subsynthem NSN 1.4). The first occurrence of Coscinodiscus plicatus $(13.9 \mathrm{Ma})$ is reported for Sections $104-643 \mathrm{~A}-12 \mathrm{H}-2$ to $-643 \mathrm{~A}$ $12 \mathrm{H}-3$. These ages are in general agreement with the chronology of Subsynthem NSN 1.5 in Figure 9 (backpocket).

\section{Subsynthem NSN 1.6}

Sediments from both Sites 642 and 643 are classified as Subsynthem NSN 1.6. At Site 643, Subsynthem NSN 1.6 is composed of slump and debris flow deposits representing not more than 0.1 m.y. of sedimentation. Ciesielski, Hasson, and Turner (this volume) assign Subsynthem NSN 1.6 at Sites 642 and 643 to the Bachmannocena circulus var. apiculata/Caryocha Zone, and they propose the existence of a major hiatus separating this sequence from the underlying sediments on the basis of silicoflagellate biostratigraphy. Goll and Bjørklund (this volume) assign Subsynthem NSN 1.6 at Site 643 to the Clathrospyris vogti Zone and Subsynthem NSN 1.6 at Site 642 to the somewhat younger Eucoronis fridtjofnanseni Zone (radiolarians). Because of the obviously disturbed nature of Subsynthem NSN 1.6 sediments in Hole 643A, this biostratigraphic distinction is moot. Both silicoflagellate and radiolarian biostratigraphy suggest a major hiatus at the base of Subsynthem NSN 1.6. The interpretation of calcareous nannofossil biostratigraphy adopted for this synthesis requires that Subsynthem NSN 1.6 can be no younger than calcareous nannofossil Zone NN6, however. A reexamination of Leg 104 calcareous nannofossils presently in progress by Jan Bachmann (pers. commun.) reveals that Subsynthem NSN 1.6 may be younger than Zone NN6. If confirmed, this result may necessitate a reinterpretation of Leg 104 chronostratigraphy. Last occurrences of the diatoms, Craspedodiscus coscinodiscus and Coscinodiscus lewisianus (10.7-12.9 Ma), are reported for Sections $104-642 \mathrm{C}-19 \mathrm{H}-5$ to $-642 \mathrm{C}-20 \mathrm{H}-2$ by Ciesielski and Case (this volume).

\section{Subsynthem NSN 2.1}

Sequences of unequal age and duration at Sites 642 and 643 are classified as Subsynthem NSN 2.1, which is older and of longer duration at Site 642. The chronostratigraphy is supported by the polarity record at Site 643 and Bolboforma biostratigraphy at both sites. Subsynthem NSN 2.1 at Site 643 differs biostratigraphically from Site 643 in the presence of the Spirosigmoilinella Zone (benthic foraminifers) below the Cibicides/Uvigerina Zone. Additionally, the I. aquaeductum Zone (dinoflagellates), Bolbo- 
forma reticulata Zone and part of the $B$. compressispinosa Zone are missing. A younger top for Subsynthem NSN 2.1 at Site 643 is indicated by the thickness of the Hexalonche esmarki Zone (radiolarian), which is $3 \mathrm{~m}$ thick in Hole $642 \mathrm{C}$ and $10.5 \mathrm{~m}$ thick in Hole 643A. Ciesielski and Case (this volume) report last occurrences of $C$. yabei, C. plicatus, and D. lauta (7.3-8.7 Ma) and the first occurrence of $R$. barboi $(11.2 \mathrm{Ma})$ in Sections 104$642 \mathrm{C}-16 \mathrm{H}-4$ to $-642 \mathrm{C}-17 \mathrm{H}-1$. The latter three events are also reported for Sections 104-643A-11H-5 to $-643 \mathrm{~A}-11 \mathrm{H}-6$. The middle of this age range is in general agreement with core ages assigned to Subsynthem NSN 2.1 in Figure 9 (backpocket). The boundary between lithologic Units IIC and IID is heterochronous in Holes 642B and 642C, and this contact should be reset to the top of the calcareous unit in Core 104-642C-17H.

\section{Subsynthems NSN 2.2-NSN 2.3}

A complete and uninterrupted record of Subsynthems NSN 2.2 and NSN 2.3 appears to be present at Site 642 on the basis of local biostratigraphic criteria and magnetostratigraphy. There is no reference section to verify this conclusion, however, and a short lacuna correlative with the hiatus at Site 643 may be present at the base of the Liriospyris cricus Zone, as indicated by the abrupt occurrence (without a precursor) of $L$. cricus. Siliceous microfossils become decreasingly frequent and more poorly preserved toward the top of Subsynthems NSN 2.2-2.3 at Site 642. In Figure 9 (backpocket), Subsynthems NSN 2.2-2.3 are shown occupying the same range in Holes 642B and 642C, but the sequence may be somewhat older in Hole $642 \mathrm{C}$, which includes at its base the thin Larcospira bulbosa Zone (missing in Hole 642B). First occurrences of Thalassiosira oestrupii, Nitzschia reinholdi, and $N$. miocenica $(5.3-6.8 \mathrm{Ma}$ ) are reported for Sections $104-642 \mathrm{C}-11 \mathrm{H}-5$ to $-642 \mathrm{C}-15 \mathrm{H}-5$ by Ciesielski and Case (this volume). The minimum of this age range is in closer agreement with the ages assigned to Subsynthems NSN $2.2-2.3$ in Figure 9. The mud layer in Core $104-642 \mathrm{~B}-10 \mathrm{H}$ is probably correlative with a similar unit in Core $104-642 \mathrm{C}-11 \mathrm{H}$.

In Hole $643 \mathrm{~A}$, the chronostratigraphy of Subsynthem NSN 2.2 is not clearly understood, because of the paucity of fossil criteria, but the sequence is clearly older than the $L$. cricus Zone. Subsynthems NSN 2.2 and 2.3 are distinguished biostratigraphically in that Subsynthem NSN 2.2 includes the lower $N$. atlantica (dex.) and $A$. andalousiensis Zones and Subsynthem NSN 2.3 includes the $N$. atlantica (sin.) and $F$. filifera Zones. The thin calcareous layer in upper Core $104-643 \mathrm{~A}-8 \mathrm{H}$ is probably correlative with the similar units in Cores 104-642B$13 \mathrm{H}$ and $-642 \mathrm{C}-14 \mathrm{H}$.

\section{Subsynthem NSN 2.4}

Subsynthem 2.4 was penetrated at Sites 642, 643, and 644, and correlations are based on lithologic criteria as well as magnetostratigraphy and calcareous microfossil biostratigraphy. Siliceous microfossils are abundant in lithologic Unit II and occur sporadically in Unit IC. These siliceous microfossil assemblages do not occur in Subsynthem NSN 2.4 at Sites 642 and 643. Consequently, all of the siliceous microfossil zones listed for Subsynthem NSN 2.4 in Table 3 occur in whole or in part only at Site 644. Additionally, the upper Neogloboquadrina atlantica (dex.) and N. pachyderma (dex.) Zones (planktonic foraminifera) occur in Leg 104 recovery only at Site 644.

\section{LEG 38 CORRELATIONS}

Now that we have formulated an interpreted chronostratigraphy for Leg 104 sediments, it is of interest to compare these results with sediments from Leg 38 drill Sites. Such an attempt is presented in Figure 11, with the recoveries from 17 Leg 38 and Leg 104 sites plotted against time in the center columns. Fourteen of the 17 Leg 38 sites are included in this figure. Site 347 , which penetrated an almost identical section as that of Site 346, is not included here nor is Site $\mathbf{3 4 4}$ from the Knipovich Ridge, where only poorly-studied Neogene turbidites were recovered. No sediments were recovered at Site 351 . The geographic distribution of the studied sites approximates a circle (Fig. 1), with Sites 346 and 349 on the Jan Mayen Ridge, Sites 348 and 350 on the Iceland Plateau and in the Norway Basin, Sites 336, 352, and 337 on the Iceland-Faeroe Ridge and Aegir Ridge, Sites 338-343 on the Vøring Plateau, and Site 345 in the Lofoten Ba$\sin$. For illustrative purposes, this circle has been broken between Sites 345 and 346 and extended linearly onto the plane of the page, with Site 346 on the extreme left and Site 345 on the extreme right. Standard calcareous microfossil biozonations as correlated by Berggren et al. (1985) and the global cycle chart of Haq, Hardenbol, and Vail (1987) have been included at the far left margin of Figure 11 to facilitate comparison. The timing of cycles in the Paleogene portion of this curve have been adjusted such that they are consistent with the accompanying calcareous nannofossil chronology. These columns are flanked on the right by six biozonations that characterize Leg 38 sediments. The benthic foraminifers and dinoflagellate biozonations on the far right margin are the only Leg 104 biozonations represented on Figure 11, because they include portions of the Paleogene interval. The five other Leg 104 biozonations are restricted to the Neogene.

Although a synthesis of Leg 38 biostratigraphic data was presented by Schrader et al. (1976), we have attempted to update their results on the basis of more recent interpretations of Cenozoic chronology. Furthermore, direct comparison of stratigraphic range data between sediments from Legs 38 and 104 has led to revised age assignments for some intervals. We hope that the present correlation chart benefits from improved precision, although extensive interpretation has been necessary for some of the Leg 38 sites, as will be discussed in the following pages.

The chronology of Neogene Leg 104 sediments in Figure 11 is consistent with Figure 9 (backpocket), but we have been forced to make selections between differing age interpretations of the Paleogene intervals of Sites 642 and 643. The reasoning for these decisions has been previously discussed. The pyroclastic unit overlying the basalt sequence at Site 642 (Sections 104642D-11-2 to $-642 \mathrm{D}-14, \mathrm{CC}$ ) is inferred to be exclusively lower Eocene. The interval between lower Core 104-643A-47X and Core 104-643A-59X is also interpreted to be Eocene in age. Additionally, the ages of the interval from Sections 104-642D-6X-1 to $-642 \mathrm{D}-11 \mathrm{X}-1$ are based on siliceous microfossil data.

A simple convention has been adopted to implement biostratigraphic correlation of Leg 38 sediments. Because of the extensive analyses to which Leg 104 sediments have been subjected and their proximity to Leg 38 sites, we have used Leg 104 biostratigraphy as a correlation standard to the maximum degree possible. This is exemplified by the correlation of Neogene biosiliceous sediments in Holes $338,341,342$, and 348 by means of radiolarians (Goll and Bjørklund, this volume). If such comparisons are imprecise or impossible, we have recognized a priority of microfossil correlations to more distant localities. Where present, calcareous nannofossils have first priority as correlation indexes because of the broad zoogeographic distribution of some taxa and relatively precise chronostratigraphic knowledge of range data. In the absence of these fossils, silicoflagellates have priority in the Neogene, but diachronism is apparent in the middle Eocene silicoflagellate biozonation. Diatoms in particular as well as the other fossil groups have been useful in sorting out these problems. Silicoflagellates are again of importance in establishing the age of the oldest biosiliceous sediments in Hole 343 by means of correlation to European localities.

The diatom biozonation for the Norwegian Sea by Schrader and Fenner (1976) provided important biostratigraphic control 
for Leg 38 sediments, but it is based in part on provincial species that can be correlated to other regions only with difficulty. A revised biozonation for the Cenozoic of the Norwegian Sea based on both radiolarians and diatoms from Leg 38 material was proposed by Dzinoridze et al. (1978) (Zones I-XVI, see Fig. 9, backpocket). Fenner (1985) accepted the revisions by these authors for the Paleogene diatom zones, and she indicated that the boundary between Zones II/III (the approximate equivalent of the $C$. oblongus Zone/ $T$. barbadense Zone contact) is essentially coeval with the Brightwellia imperfecta Zone/Asterolampra marylandica Zone boundary of the low-latitude scheme (here regarded as $42 \mathrm{Ma}$; lower calcareous nannofossil Zone NP17 according to Fenner, 1984). Because of the paucity of other fossil data, this correlation is of particular importance for Norwegian Sea biostratigraphy. Fenner (1985) indicated the succession including the $T$. irregulata to $S$. pupa Zones as ranging generally over the interval from calcareous nannofossil Zone NP23 to NP25, the more conservative view that these diatom zones must be restricted to Zone NP24 and lower Zone NP25 is accepted in this synthesis. Ages in Figure 11 for the $P$. elegans and younger Zones are in reasonable agreement with the the correlations of Barron (1985a), with the exception of the hiatuses at the bases of the $C$. bihariensis, $T$. gravida var. fossilis, and $R$. bulbosa Zones. Additionally, the T. oestrupii Zone is given a longer range ( $4 \mathrm{~m} . \mathrm{y}$.) and the base of the $C$. marginatus Zone is regarded as 5-5.5 Ma as opposed to 9.5 Ma of Barron (1985a). The chronology of Neogene diatom zones in Figure 11 applies only to Sites 338 and 348 , which serve as their reference localities. The chronology of zones proposed by Dzinoridze et al. (1978) is in general accord with Figure 11, although Zone V is regarded as upper Eocene as opposed to lower Oligocene and the correlation of Sites 338 and 340 by these authors is not accepted here.

The disposition of Paleogene radiolarian zones in Figure 11 is consistent with the succession proposed by Bjørklund (1976), with the exception that the Lithomitra sp. A Zone is shown as having two occurrences in the upper Oligocene and lower Oligocene separated by the Ceratocyrtis robustus Zone and Phorticium sp. A Zone. Dzinoridze et al. (1978) also proposed an early Oligocene age (their Zone VI) for the Lithomitra sp. A Zone sediments of Site 337. Recognition of the Lithomitra sp. A Zone is here suggested as resulting from diversity-impoverished faunas in which thin-walled species have been preferentially dissolved and only a few species with massive skeletons remain (i.e., Lithomitra).

A brief biostratigraphic synopsis of each Leg 38 hole represented in Figure 11 will be followed by some conclusions concerning the geologic history of the Norwegian Sea based on the recoveries of both Legs 38 and 104. Although the upper Pliocene-Pleistocene glaciomarine sediments in each hole are approximately represented in Figure 11, these remarks will be focused largely on the Tertiary strata. For brevity, citations for each biostratigraphic determination have been omitted, but authorship is attributed for each fossil group in Figure 11. Sediment descriptions as well as general discussions of foraminifer assemblages in each hole (contributed by J. E. van Hinte) are taken from Talwani et al. (1976).

\section{Site 346}

A 187.0-m sedimentary section was continuously cored at Site 346 on the Jan Mayen Ridge (water depth, $732.0 \mathrm{~m}$ ), and drilling was terminated before basement was reached. A glaciomarine interval $32.3 \mathrm{~m}$ thick (rock Unit 1A) overlies the Tertiary succession, which was divided into six rock units and is presented as three unconformity-bounded sequences in Figure 9 (backpocket). Biostratigraphic control is poor in all three sequences and becomes increasingly worse with depth.
The upper sequence (rock Units 1B-2C) consists of $69.2 \mathrm{~m}$ (32.3-101.5 mbsf) of alternating terrigenous sandy mud and biosiliceous sandy mud beds, which are locally intensively bioturbated and contain abundant sponge spicules as well as other generally poorly preserved siliceous microfossils (Sections 38$346-4-5$ to $38-346-11, C C)$. The age of this sequence is not easy to determine. The sparse diatom assemblage of Sections 38-3469-5 to -346-11-4 was referred to the Coscinodiscus plicatus Group Zone, although the boundary criteria taxa were not identified. Six long-ranging silicoflagellate species in Sections 38-346-5-3 to -346-6-2 were referred to the Corbisema triacantha Zone, although the same assemblage could be as old as the upper Naviculopsis lata Zone. The few radiolarians reported for this sequence range no higher than the Stichocorys biconica Zone of Site 338. The best age indicators are the presence of zone IIa dinocysts in Cores 38-346-5 to -346-7. There is no other biostratigraphic information for Cores $38-346-8$ to $-346-11$, which are included in this sequence because of the lithologic association and the presence of Miocene diatoms. Thus, the top of the sequence can be dated as approximately $19 \mathrm{Ma}$ with relative confidence, but its base is only arbitrarily assigned an age of $22 \mathrm{Ma}$. This sequence is separated from the overlying glacial sediments by a hiatus of approximately $18 \mathrm{~m} . \mathrm{y}$.

The middle sequence (rock Unit 2D) consists of $20.3 \mathrm{~m}$ (101.5-121.8 mbsf) of terrigenous muds (Sections 38-346-12-1 to -346-14-2). There are two occurrences of the calcareous benthic foraminifers, Angulogerina gracilis, near the base of the sequence. This species is restricted to Zones NSB6A and NSB9 in the North Sea according to King (1983). A dinocyst flora questionably correlated to zone III occurs sporadically in Core 38346-12. This flora includes Operculodinium centrocarpum, which has discontinuous occurrences beginning in the Impagidium sp. 1 Zone at Site 643 and is abundant in the Ascostomocystis granosa Zone. Therefore, this sequence is assigned an age of 29-30 Ma in Figure 11, although it may be somewhat younger. As shown, the upper and middle sequences are separated by an $8-m$.y. hiatus.

The lower sequence (rock Unit 3) consists of $65.2 \mathrm{~m}$ (121.8$187.0 \mathrm{mbsf}$ ) of interbedded massive and generally lithified sandy mudstones and graded turbidites (Sections 38-346-14-2 to -34620, CC). The mudstones are intensively bioturbated. The entire sequence was assigned to the Spiroplectammina spectabilis Zone (benthic foraminifers), but $S$. spectabilis has only rare and sporadic occurrences above Core 38-346-20. The last occurrence of this species is an index marker for the middle Eocene/upper Eocene boundary in Norwegian offshore regions (Skarbø and Verdenius, 1986), and King (1983) places this datum somewhat lower (mid calcareous nannofossil Zone NP16). In contrast, $S$. spectabilis ranges throughout the Eocene of the Labrador Sea (Miller et al., 1982). Kaminski (1988) attributed biostratigraphic significance to the first occurrences of Budashevaella cf. multicamerata and Dorothia principiensis in the lower Spirosigmoilinella $\mathrm{sp}$. Zone in Hole 643A. However, B. cf. multicamerata is consistently present to the base of Hole 346 in the absence of both $D$. principiensis and Spirosigmoilinella sp. Consequently, this lowest sequence in Hole 346 is here assumed to be older than the Spirosigmoilinella sp. Zone of Hole 643A. Because of a similar faunal association, we assume that these strata in Hole 346 may be approximately coeval with the sequence from Sections 345 $22-1$ to $-345-32-4$, a conclusion shared by Kaminski (1988). Although characterized by numerous displaced specimens, the zone IV/V dinocyst flora in Cores $38-346-15$ to $-346-16$ includes Areosphaeridium arcuatum which is restricted to the $A$. arcuatum Zone and Chiropteridium lobospinosum Zone of Site 643. However, a 12-m.y. hiatus between these zones has been inferred in this chapter, and the interval including both zones spans most of the middle and late Eocene. For this reason, the 
lower sequence is assigned an age of 38-40 Ma in Figure 11, and it is separated by an 8-m.y. hiatus from the middle sequence. This age is consistent with the sparse Reticulofenestra umbilica Zone calcareous nannofossils observed in equivalent sediments at Site 347 (Cores 38-347-2 and -3). The presence of S. spectabilis may be attributed to the reworking processes so apparent in these sediments. There are no recorded co-occurrences in the Norwegian Sea of this species with $B$. cf. multicamerata or other species restricted to the Spirosigmoilinella-Karreriella siphonella Zone.

\section{Site 349}

A 319.5-m sedimentary section was discontinuously cored at Site 349 on the Jan Mayen Ridge (water depth, $915 \mathrm{~m}$ ), and the hole was terminated before basement was reached. The sediments recovered from this hole have been described in three rock units, which are all predominantly terrestrial clastics. Because of the paucity of fossils, the sequence divisions of this succession follow these rock units. The glaciomarine interval (Unit 1; Gephyrocapsa oceanica Zone and younger) is $59.3 \mathrm{~m}$ thick and is separated from the underlying sediments by a $28-\mathrm{m}$.y. hiatus.

The upper sequence of the pre-glacial Cenozoic succession (rock Unit 2) consists of $60.3 \mathrm{~m}$ (59.3-119.6 mbsf) of massive hemipelagic muds, which are glauconitic throughout and contain abundant volcanic ash in the upper part (Sections 38-349$2-4$ to -349-5-4). This sequence is barren of all siliceous and calcareous microfossils, except for a thin bed (Sections 38-349-3, $\mathrm{CC}$ to $-349-4-1$ ) bearing a calcareous benthic foraminifer assemblage including Turrilina alsatica. This species ranges throughout the Oligocene of the North Sea according to King (1983). The zone III dinocyst flora in Section 38-349-3-2 includes $O$. centrocarpum, which has its oldest occurrence at Site 643 in the Impagidium sp. 1 Zone. Therefore, the sequence is regarded as coeval with the Oligocene sequences of Site 346 , and these sediments are assigned an age of 29-30 Ma. A conglomerate bed (unobserved on the core $\log$ ) is reported to separate this sequence from the underlying Unit 3 , and we infer a hiatus of 4 m.y.

The lower sequence (rock Unit 3) consists of 119.9 m (119.6$319.5 \mathrm{mbsf}$ ) of indurated and locally bioturbated sandy mudstones and mudstones interbedded with conglomerates, breccias and sandstones (Sections 38-349-5-4 to $-349-13$, CC). Graded bedding is common. A restricted and occasionally etched flora of Isthmolithus recurvus interval calcareous nannofossils is recorded in Sections 38-349-5-6 to -349-12-4. The sequence is largely barren of all benthic foraminifers, but a horizon at Section 38-349-10, CC contains a calcareous assemblage including Cancris subconicus, which has its extinction level in the early Oligocene (top of zone NSB7a of King, 1983). The entire sequence was assigned to the $S$. spectabilis Zone on the basis of rare occurrences of the nominate species in Cores 38-349-8 and $-349-13$, and a pre-late Eocene age is supported by sporadic occurrences of zone IV/V dinocysts floras in Sections 38-349-6-2 to $-349-10-2$, which include Deflandrea phosphoritica and Cribroperidinium giuseppei. These two species co-occur in Hole 643 A only in the Adnatosphaeridium vittatum Zone (upper lower to lower middle Eocene). Because of the evidence of extensive reworking in these sediments however, we regard these sparse middle Eocene indicators as displaced and favor a late Eocene to early Oligocene age $(34.5-38 \mathrm{Ma})$ for the lower sequence.

\section{Site 348}

A 526.6-m sedimentary section was discontinuously cored to basement at Site 348 (water depth, $1763 \mathrm{~m}$ ) on the Iceland Plateau. This succession was described as three rock units, includ- ing $63.7 \mathrm{~m}$ of glaciomarine muds with minor calcareous nannofossil muds and a few volcanic ash layers (rock Unit 1; Sections 38-348-1-1 to -348-5-4). Sedimentation was regarded as essentially continuous since possibly the late Oligocene, but Goll and Bjørklund (this volume) recognize at least three Tertiary sequences. The upper two sequences of Figure 11 closely follow the interpretation of these authors.

The upper sequence consists of $101.5 \mathrm{~m}$ (64.0-165.5 mbsf) of biosiliceous mud containing numerous layers of monospecific calcareous nannofossil ooze (Coccolithus pelagicus) (upper rock Unit 2), which are underlain by hemipelagic muds with 10$14 \%$ siliceous microfossils and abundant volcanic ash (Sections 38-338-5-5 to -338-12-3). Thalassiosira oestrupii Zone to Cymatosira biharensis Zone diatoms and Distephanus speculum Zone to Mesocena circulus Zone silicoflagellates are present. Locker and Martini (this volume) refer silicoflagellates in Sections 38348-6-1 to -348-8-3 to their Distephanus aculeatus Zone (2.5$5.4 \mathrm{Ma}$ in Figure 10 [backpocket], this chapter); Sections 38348-9-3 to -348-10, CC to their Mesocena diodon Zone (5.4-6.0 $\mathrm{Ma})$; and questionably refer the sediments below Section 38348-11-1 to the Paramesocena circulus apiculata Zone. The first occurrence of Thalassiosira oestrupii (ca. $4.5 \mathrm{Ma}$ at Site 642) is positioned at the base of the Rhizosolenia barboi Zone at Site 348 . These tie points suggest an age range of 3.5-6.0 Ma for this sequence, which is bounded at its top and base by hiatuses of $3.0 \mathrm{~m} . \mathrm{y}$. and $4.0 \mathrm{~m} . \mathrm{y}$, respectively.

The next sequence consists of $99.5 \mathrm{~m}$ (165.5-265.0 mbsf) of hemipelagic muds (Sections $38-348-12-3$ to $-348-18, \mathrm{CC}$ ). The sequence includes Mesocena circulus Zone silicoflagellates, and the succession of diatom floras ranging from the Goniothecium tenue Zone to the Thalassiosira gravida var. fossilis Zone is known only from these sediments. Radiolarian faunas that have not been observed in Hole 348 range from the Liriospyris cricus Zone to the $E$. fridtjofnanseni/C. reuschi Zone. The dinocyst flora in Sections $38-348-12-2$ to $-348-13-2$ was questionably assigned to zone IIa, but a younger age for the base of this sequence is supported by the first common occurrence of $M$. communis (benthic foraminifers) in Section 38-348-18, CC. The diatom flora of Section 38-348-17-1 includes Coscinodiscus lewisianus, which is reported to range no higher than $12.8 \mathrm{Ma}$ according to Baldauf (1987). Locker and Martini (this volume) questionably identify the Paramesocena circulus apiculata Zone (6.0-?10.2 Ma) in Sections $38-348-12-3$ to $-348-13$, CC and questionably identify the upper Corbisema triacantha Zone (?13.4-14.5 Ma) in Sections $38-348-14-1$ to $-348-17$, CC. The age range $8.5-13.0 \mathrm{Ma}$ is assigned to this sequence, which is bounded at its base by a hiatus of $1.5 \mathrm{~m} . \mathrm{y}$.

The lower sequence (rock Unit 3) consists of $261.3 \mathrm{~m} \mathrm{(265.5-}$ $526.8 \mathrm{mbsf}$ ) of indurated and moderately deep water mud/mudstones and clay/claystones that become increasingly coarse-grained and bioturbated with depth. The sequence is generally poorly fossiliferous, and no fossils were reported for Cores 38-348-19 to $-348-23$ and Cores $38-348-30$ to $-348-32$. The presence of $\mathrm{He}$ licosphaera ampliaperta Zone calcareous nannofossils in Sections 38-348-24-4 to -348-26-5 provides good age control (16-19 $\mathrm{Ma}$ ) for the middle of the sequence. There is no evidence for the age of the top of the sequence, which has been arbitrarily placed at $15 \mathrm{Ma}$. The oldest fossiliferous strata occur in Core 38-348-32, which contains Cyclammina acutidorsata-Cyclammina Subzone agglutinated benthic foraminifers of indeterminate precise age, but indicative of bathyal depths according to Berggren and Schnitker (1981). Sections 38-348-24-1 to -348-30-3 is reported to be correlative with the Evittosphaerula paratabulata Zone (dinocysts) of Site 643 (18.5-21 Ma). The basal age for the sequence is arbitrarily placed at $22 \mathrm{Ma}$, which is significantly older than the 18.2-19.4 Ma isotope ages for Site 348 basalts (Kharin et al., 1976). 


\section{Site 350}

A 364-m sedimentary section was discontinuously cored to basement at Site 350 (water depth, $1275 \mathrm{~m}$ ) on a southern extension of the Jan Mayen Ridge. The sediments in this hole were divided into three rock units, the uppermost of which is $55.5 \mathrm{~m}$ of glacio-marine muds and sandy muds. The older Tertiary succession is also dominated by terrigenous clastics bearing few fossils, and the two sequences shown in Figure 11 are consistent with rock Units 2 and 3 .

The upper sequence consists of $171 \mathrm{~m}$ (55.5-226.5 mbsf) of alternating clay/claystone and mud/mudstone beds that are locally bioturbated volcanic ash beds throughout the unit and distal turbidites are present at the base. Few fossils have been reported for this unit. The presence in Core 38-350-3 of the benthic foraminifer Martinotiella communis, as well as a rare radiolarian assemblage similar to the Actinomma holtedahli Zone suggests an age of $14 \mathrm{Ma}$ for the top of this thick sequence, but there is no biostratigraphic control for its base, which is arbitrarily assigned an age of $19 \mathrm{Ma}$.

The lower sequence consists of $137.5 \mathrm{~m}$ (226.5-364 mbsf) of bioturbated claystone and mudstone interbedded with volcanic ash, recrystallized limestone and breccia (Sections 38-350-9-1 to $-350-14-2$ ). The basal breccia was interpreted as a slump deposit and is overlain by proximal turbidites. These beds grade upwardly into finer grain sizes. Rare specimens of $S$. spectabilis (benthic foraminifers) occur sporadically in Sections 38-35010-2 to -350-13-1. Scattered dinocyst occurrences in Sections 38350-8-3 to -350-14-1 include Thalassiphora pelagica and Deflandrea phosphorica, which range no higher than Core 104-643A47X (lower Areosphaeridium actinocoronatum Zone). Neither of these species is given important biostratigraphic status by Manum (pers. commun.), but the single occurrence of Gonyaulacysta giuseppi (= Cribroperidinium quiseppei) in Core $38-350-11$ is regarded as a reliable Eocene marker. The only other reported biostratigraphic indicators are sparse $I$. recurvus Zone calcareous nannofossils in Section 38-350-14-2 and a poorly preserved assemblage of Oligocene diatoms in Section 38-350-12-1. Consequently, we regard this sequence as approximately coeval with the lower Oligocene sequence at Site 349. These oldest sediments at Site 350 are assigned to the age range $34.5-38 \mathrm{Ma}$ and are bounded above by a 16-m.y. hiatus.

\section{Site 352}

Two holes were drilled with discontinuous coring to a total depth of $122.5 \mathrm{~m}$ at Site 352 (water depth, $990 \mathrm{~m}$ ) on the southern flank of the Iceland-Faeroe Ridge, but the site was abandoned for technical reasons. The sediments recovered at this site were described in two rock units, the upper of which is Pleistocene muds and sandy muds of unknown exact thickness (? $54.5 \mathrm{~m}$ ).

The underlying sequence (rock Unit 2) consists of about $28.5 \mathrm{~m}$ of calcareous nannofossil ooze and chalk containing chert zones (Sections 38-352A-1-1 to -352A-3, CC). Siliceous microfossils are rare and very poorly preserved in this sequence, and dinocysts were not reported. Benthic and planktonic foraminifers are abundant and diverse, and Berggren and Schnitker (1981) proposed a middle to lower bathyal depositional environment. The Sphenolithus distentus Zone calcareous nannofossils establish the probable age of this sequence as $28-30 \mathrm{Ma}$. The lower portion of this age range (29-30 Ma) is inferred here, because of similarities to the base of the Oligocene sequence in Hole 338. A 28-m.y. hiatus separates this sequence from the glacio-marine section.

\section{Site 336}

A $484.5-\mathrm{m}$ sedimentary section was discontinuously cored to basement at Site 336 (water depth, $811.0 \mathrm{~m}$ ) on the northern flank of the Iceland-Faeroe Ridge. This succession was divided into nine sedimentary rock subunits, of which Units $1 \mathrm{~A}-1 \mathrm{C}$ were interpreted as glacio-marine (168.5 m thick; Cores $38-336-1$ to $-336-14$, CC). The interbedded clays, muds, and sandy muds with dropstone of the upper subunit (Gephyrocapsa oceanica Zone) are underlain by graded beds and distal turbidites (Subunit 1B; Sections 38-336-9-4 to -336-11-2), which in turn are underlain by massive muds and sandy muds (Subunit 1C; Sections 38-336-11-2 to $-336-14, \mathrm{CC}$ ). The entire interval may be conformable. The Cycladophora davisiana Zone (radiolarians) extends down to Core 38-336-10, and T. oestrupii Zone to T. kryophila Zone (diatoms) are reported for Cores 38-336-1 to -336-12. An age of $2.5 \mathrm{Ma}$ is assigned to the base of this interval.

A 21-m.y. hiatus separates this youngest interval from the upper Oligocene sequence (rock Unit 2A), which consists of $31.5 \mathrm{~m}$ (168.5-200.0 mbsf) of bioturbated glauconitic mudstones (Sections 38-336-15-1 to -336-18-4). The upper and middle strata bear $7-55 \%$ siliceous microfossils composed primarily of fragmented sponge spicules. Both siliceous and calcareous microfossils are locally poorly preserved, and the biostratigraphic evidence is partially contradictory. Sections $38-336-15-1$ to $-336-$ 18-3 contain Naviculopsis lata Zone silicoflagellates, and Sceptroneis pupa Zone diatoms were reported for Sections 38-33616-2 to -336-19-2. These two zonal assignments appear to be somewhat inconsistent. Abundant but etched $S$. distentus Zone calcareous nannofossils were determined for Sections 38-336$16-3$ to -336-16-5. The advent level of Discolithina enormis in Section 38-336-16-2 marks the base of the Sphenolithus ciperoensis Zone, which ranges up to Section 38-336-15-1. We regard the absence of $D$. enormis in Core $38-336-16$ as a dissolution effect, however, and the entire sequence is correlated to the $S$. ciperoensis Zone. Broken specimens of $M$. communis (benthic foraminifers) in Section 38-336-15-1 probably represent caving contamination in an assemblage also including such Oligocene indexes as $A$. gracilis and T. alsatica. Zone III dinocysts were reported for Section 38-336-16-5. The presence of Tanyosphaeridium sp. I may suggest a younger age restricted to the $E$. paratabulata Zone at Site 643, although this species is not regarded as biostratigraphically significant (Manum, pers. commun). Radiolarians in Sections 38-336-15, CC to -336-19, CC were assigned to the Lithomitra sp. A Zone, but occurrences of Velicucculus oddgurneri and Ceratocyrtis mashae indicate an age no older than Section 38-338-19,CC. As a result of these somewhat conflicting biostratigraphic data, we rather arbitrarily propose an age range of $27-28 \mathrm{Ma}$ for this sequence.

The remainder of the hole (rock Units $2 \mathrm{~B}$ to $3 \mathrm{C}$ ) is provisionally divided into two sequences on the basis of sparse fossil data. The precise horizon separating these two sequences is unknown, but changes in the dinocyst and benthic foraminifer assemblages in lower Core 38-336-27 and Core 38-336-28, respectively, and an increase in the degree of sediment induration in Core $38-336-28$ is regarded as evidence of a hiatus.

The lower Oligocene sequence (rock Units 2B-mid 2C) consists of approximately $96 \mathrm{~m}$ (200.0-296.0 mbsf) of glauconitic mudstones overlying massive and bioturbated mudstones and sandy mudstones (Sections 38-336-18-4 to -336-28-3). The interval from Section 38-336-22-6 to the base of the sequence contains a sparse and restricted flora of calcareous nannofossils, including $I$. recurvus. If the recognized range of this species is to be accepted as the primary age indicator, then the sequence is probably lower Oligocene. Co-occurrences in Sections 38-33618-2 to -336-20-5 of the dinocysts Deflandrea phosphoritica and Thalassiphora pelagica may be the result of either upward reworking, as interpreted for the Oligocene sequence at Site 350 , or the broad morphological ranges of these species. Neither of these species is regarded as biostratigraphically important by Manum (pers. commun.). However, the flora in Site 336 in- 
cludes Hystrichokolpoma rigaudae, and this species complex ranges no lower than the base of the Impagidinium sp. 1 Zone at Site 643. This datum is poorly constrained, however, as the base of the Impagidinium sp. 1 Zone is interpreted in this chapter to be bounded by a 7-m.y. hiatus. Sedimentation represented by Cores 38-336-18 to -336-20 during the older part of this hiatus is inconsistent with the calcareous nannofossil biostratigraphy. Both $H$. rigaudae and $C$. dispersum range down to the base of zone III at Site 338, but they are not recorded in the poorly preserved dinocyst floras of the chalks in Cores 38-338-24 to $-338-25$. As shown in Figure 11, the base of the ranges of these species is approximately $35 \mathrm{Ma}$ (the upper part of the lower Oligocene sequence in Site 336). More problematical are occurrences of reliable Eocene dinocysts, Gonyaulacysta cf. giuseppei and Phthanoperidinium amoenum, in Sections 38-336-21-5 to -336-27-5. The calcareous benthic foraminifers in Sections 38336-22-5 to -336-28, CC are reported to compare with the Asse Clay of Belgium (Zones NP14-NP16 according to Aubry, 1985) and Barton Beds of England (Zones NP16-NP17 according to Aubry, 1985). This fauna was also interpreted by Berggren and Schnitker (1981) as late Eocene neritic, but these ages are in conflict with the calcareous nannofossil floras. This sequence is assigned to the age range $34-37 \mathrm{Ma}$, and the glauconites of the top sediments are assumed to have formed on the upper erosion surface.

Rock Units lower $2 \mathrm{C}$ and $3 \mathrm{~A}-3 \mathrm{C}$ are combined as one sequence (188.5 $\mathrm{m}$ thick; $296.0-484.5 \mathrm{mbsf}$ ) in the absence of contravening fossil evidence (Sections 38-336-28-4 to -336-40-1). The indurated massive mudstones of lower Unit $2 \mathrm{C}$ are underlain by oxidized claystones derived by weathering of the subjacent basalt and showing evidence of soil development (Units $3 \mathrm{~A}-3 \mathrm{C})$. The boundary between this sequence and the one above is difficult to determine biostratigraphically. The continued presence of $I$. recurvus Zone calcareous nannofossils down to Core 38-336-30 implies that Cores 38-336-29 to -336-30 should be placed in the Oligocene sequence. However, sediments as high as Section 38-350-29-1 contain the foraminifer assemblage of the older fossiliferous strata. Cores $38-336-38$ to $-336-40$ are barren of fossils. Marine fossils appear in the succession in Section 336-37, CC in the form of a sparse and restricted flora of Reticulofenestra umbilica Zone calcareous nannofossils. The entire upper portion of this sequence is correlated to this zone despite the presence of $I$. recurvus as low as Section 38-336-30-2. Specimens of this species are regarded as displaced. The benthic foraminifers in Sections 38-336-29-1 to -336-36, CC include $S$. spectabilis among a lower neritic to upper bathyal fauna (Berggren and Schnitker, 1981). The presence of the dinocyst Wetzeliella articulata in Section 38-336-33-5 suggested a correlation to zones VI-VIIb, and this species is abundant in Hole 643A only in the Rottnestia borussica Zone. Wetzeliella articulata is known to be more long ranging elsewhere, however, and Core 38-336-33 is here interpreted as having been deposited during the 11-m.y. hiatus between the middle and lower Eocene sequences in Hole 338. On the basis of this sparse data, we assign the lower sequence to the age range 43-47 Ma.

\section{Site 337}

A 113-m sedimentary section was continuously cored to basement at Site 337 (water depth, $2631.0 \mathrm{~m}$ ) on the Aegir Ridge. The glacio-marine interval includes $47.0 \mathrm{~m}$ of mud and sandy mudstones with volcanic ash and calcareous nannofossil ooze intercalations (Sections 38-337-1-1 to $-337-5, \mathrm{CC}$ ), which are separated from the underlying Tertiary sequence by a 30 m.y. hiatus.

This sequence (rock Unit 2) is composed of $70.8 \mathrm{~m} \mathrm{(47.0-}$ $113.0 \mathrm{mbsf}$ ) of stratified pelagic muds and minor clay with clay balls and clasts, zeolitic patches, and volcanic ash beds (Sec- tions $38-337-6-1$ to $-337-12-5$ ). As pointed out by Kaminski (1988), both geophysical and partially contradictory biostratigraphic evidence suggests an age of 33-34 Ma for the basement basalts and basal sediments of Site 337. Cores 38-337-6 to $-337-8$ are totally barren, and only siliceous microfossils are reported for Cores $38-337-9$ to $-337-12$. Sections $38-337-9-5$ to -337-11-2 were reported to contain a Coscinodiscus oblongus Zone diatom flora, but the index species for this taxon-range zone, $C$. oblongus, was not observed, and the zone was identified on the basis of secondary markers. Of the four diatom taxa recorded for this interval, Navicula udintsevii is restricted to the lower C. oblongus zone of Site 338. Dzinoridze et al. (1978) assign co-occurrences of Rouxia obsea and Huttonia norwegica to early Oligocene Zone VI, however. $N$. biapiculata Zone silicoflagellates were reported for Sections 38-337-9-4 to -337-12, CC. The latter zonal determination is supported by the presence of a radiolarian fauna that is apparently younger than the middle Eocene assemblages at Sites 338 and 340 . Consequently, the sequence is assigned to the age range $31-33 \mathrm{Ma}$.

\section{Sites 339 and 340}

Sedimentary sections $108.0 \mathrm{~m}$ and $104.5 \mathrm{~m}$ thick were continuously drilled at two closely-spaced localities, Site 339 (water depth, $1276.0 \mathrm{~m}$ ) and Site 340 (water depth, $1244.0 \mathrm{~m}$ ), respectively, on or near a diapir on the inner Vøring Plateau. Similar lithologies were penetrated, but both sites are shown in Figure 11 , because of conflicting biostratigraphic determinations. The succession was described as two rock units at each site. The glacio-marine intervals consist of sandy mud with dropstones and clay balls intercalated with authigenic carbonates and calcareous nannofossil and siliceous oozes. At Site 339, this interval is $74.5 \mathrm{~m}$ thick and includes abundant clasts of the underlying sedimentary unit in the lower $19 \mathrm{~m}$ (Sections 38-339-1-1 to $-339-8, \mathrm{CC}$ ). At Site 340 , the glacio-marine unit is only $9.5 \mathrm{~m}$ thick (Core 38-340-1).

Underlying units of diatom ooze $33.5 \mathrm{~m}$ thick (74.5-108 mbsf) and $95 \mathrm{~m}$ thick (95-140.5 mbsf) were cored in Holes 339 and 340 , respectively (Sections 38-339-9-1 to $-339-12$, CC and $38-340-2-1$ to $-340-11, C C)$. Considerable bedding disturbance is apparent in both holes, and structural overturning is biostratigraphically evident in Hole 340 . Under these circumstances with old sediments tectonically injected through younger strata, partial blending of fossil assemblages is highly probable, and biozonations based on last occurrences of index taxa may result in spuriously young age determinations. Calcareous microfossils are essentially absent in these diatom oozes. An early to middle Oligocene age was determined for the ooze sequence in Hole 339 on the basis of $N$. biapiculata Zone silicoflagellates. Corbisema bimucronata Zone to Naviculopsis foliacea Zone silicoflagellates in the ooze sequence in Hole 340 indicated a middle to late Eocene age.

All three siliceous microfossil groups in Hole 340 are in agreement that the Eocene sequence in Hole 340 broadly overlaps and is somewhat older than the middle Eocene sequence in Hole 338. Diatoms in Hole 340 represent the Coscinodiscus oblongus Zone, Triceratium barbadense Zone and an unzoned middle Eocene interval. Lophocorys norvegiensis Zone and $\mathrm{Ca}$ locyclas talwanii Zone radiolarians are also present. This sequence is assigned to the age range 41.5-44.5 Ma.

Diatoms only in Cores $38-339-6$ to $-339-7$ at Site 339 are referrable to the $C$. oblongus Zone and $T$. barbadense Zone, however, and Cores 38-339-10 to -339-12 were regarded as having an older middle Eocene age than was penetrated in the diatom ooze facies of Sites 338 and 340 . Such a determination is in strong contrast to the younger age deduced by means of silicoflagellate biostratigraphy. Dzinoridze et al. (1978) record the presence of Rouxia obsea in this interval (their lower Oligocene 
Zone V), and this species is also present in the Oligocene sediments of Site 337 (their Zone VI). Persistent occurrences of Dictyocha hexacantha (silicoflagellate) in low frequencies throughout this interval indicate a correlation to calcareous nannofossil Zones NP16-NP19, according to Locker and Martini (1987). There are many floral dissimilarities between the $N$. biapiculata Zone of Sites 337 and 340. Radiolarians of the Artostrobus quadriporus Zone in Cores 38-339-10 to -339-12 are distinctively different from the faunas of Sites 338 and 340. In Figure 11 , Cores $38-339-6$ to $-339-7$ are shown as a thin sequence in the age range $42.0-42.5 \mathrm{Ma}$. Cores $38-339-8$ to $-339-9$ (not shown) probably contain mixed fossil assemblages. It is not possible at this time to determine the precise age range of Cores 38-339-10 to $-339-12$, but they are tentatively assigned to the range $37.0-$ $38.5 \mathrm{Ma}$, largely on the basis of silicoflagellate biostratigraphy.

\section{Site 341}

A 456.0-m sedimentary section was discontinuously cored at Site 341 (water depth, $1439 \mathrm{~m}$ ) on the inner Vøring Plateau, and the hole was terminated for safety reasons before reaching basement. This succession was described in seven rock units, the upper $352.3 \mathrm{~m}$ of which (rock Units $1 \mathrm{~A}-3 \mathrm{~A}$ ) consist of glacio-marine muds and calcareous muds with dropstones and ooze intercalations. Pleistocene and reworked calcareous nannofossils and dinocysts as old as Eocene and Cretaceous are present in these sediments as well as Distephanus speculum Zone silicoflagellates and Rhizosolenia barboi Zone and Nitzschia sp. 8 Zone diatoms. The assignment of Section 38-341-7-2 to the Bolboforma intermedia Zone by Qvale and Spiegler (this volume) appears to be anomalously young. The Pleistocene interval is separated from the underlying sediments by a hiatus of $6 \mathrm{~m}$.y.

On the basis of criteria discussed by Goll and Bjørklund (this volume), the Miocene strata are divided into two sequences that are not consistent with rock Units 3B-3C. Both sequences contain Mesocena circulus Zone silicoflagellates and Reticulofenestra pseudoumbilica Zone calcareous nannofossils.

The upper sequence consists of $75.2 \mathrm{~m}$ (352.3-427.5 mbsf) of calcareous diatomite and calcareous diatomaceous mudstones with $40-50 \%$ siliceous microfossils and $20-30 \%$ carbonates (rock Unit 3B) overlying massive, lithified mudstones with $30-50 \%$ siliceous microfossils (upper rock Unit 3C) (Sections 38-341-26-1 to $-341-31, C C)$. Differentiation of this sequence from the underlying strata is supported by the dinocyst floras (unspecified) in Cores $38-341-25$ to $341-31$, which are distinctively younger than the zone Ia assemblage. Qvale and Spiegler (this volume) assign Sections 38-341-26-3 to -341-27-2 to the Bolboforma fragori and Bolboforma compressispinosa Zones (8.3-9.5 Ma in Fig. 10, backpocket) and Section 38-341-28-2 to the Bolboforma reticulata Zone $(9.5-13.6 \mathrm{Ma})$. This sequence is assigned an age of $8-11 \mathrm{Ma}$ and is separated from the lower sequences by a 1.5 -m.y. hiatus.

The lower sequence (lower rock Unit 3C) consists of $28.5 \mathrm{~m}$ (427.5-456.0 mbsf) of massive lithified mudstones (Sections 38$341-32-1$ to $-341-34, \mathrm{CC}$ ). The dinocyst flora (unspecified) of Sections 38-341-32-2 to -341-33-5 was correlative with zone Ia. The sequence is assigned to the age range 12.5-13.5 Ma.

\section{Site 338}

A 401.8-m sedimentary section was essentially continuously cored to basement breccia at Site 338 (water depth, $1297 \mathrm{~m}$ ) just west of the Vøring Escarpment. This succession was described as six rock subunits, including $57.0-66.5 \mathrm{~m}$ of glacio-marine muds and sandy muds with dropstones and calcareous ooze intercalations containing Pseudoemiliania lacunosa Zone to Emiliania huxleyi Zone calcareous nannofossils (rock Unit 1; Sections 38-338-1-1 to 38-338-6, CC). The underlying strata (beginning with Core $38-338-8$ ) are divided into eight sequences, the upper five of which have been recognized on the basis of the revised radiolarian biozonation of Goll and Bjørklund (this volume, not shown in Fig. 9, backpocket). Calcareous nannofossils are absent in these upper sequences. Core 38-338-7, consisting only of a core catcher, is probably an additional sequence that is not treated here.

The upper sequence (lower rock Unit 2A) consists of $21.6 \mathrm{~m}$ (76.0-97.6 mbsf) of massive muddy diatom ooze (Sections 38$338-8-1$ to $-338-10-2$ ). Fossil assemblages include: zone Ia and zone Ib dinocysts, $M$. circulus Zone and $C$. triacantha Zone silicoflagellates and A.ingens Zone to $C$. plicatus Group Zone diatoms. The first common occurrence of the diatom Denticulopsis hustedti in Section 38-338-10-2 indicates an age of 13.8 Ma. Goll and Bjørklund (this volume) record radiolarians of the Pseudodictyophimus horrida Zone (ca. 14.0-14.5 Ma), Actinomma plasticum Zone (ca. 14.5-14.7 Ma) and Cyrtocapsella kladaros Subzone A (ca. 14.8-14.9 Ma) in this sequence. Locker and Martini (this volume) refer Sections $38-338-8-3$ to $-338-10-1$ to the upper Corbisema triacantha Zone (silicoflagellates; 13.414.5 Ma), and the lower Corbisema triacantha Zone (14.5-18.6 $\mathrm{Ma}$ ) is present from Section 38-338-10-2 to the base of the sequence. The sequence is assigned to the age range 14.0-14.8 Ma.

The second sequence (upper rock Unit 2B) consists of $19.4 \mathrm{~m}$ (97.6 to $117.0 \mathrm{mbsf}$ ) of diatom ooze (Sections 38-338-10, CC to -338-12-2). Fossil assemblages include: zone Ic dinocysts and $C$. triacantha Zone to $N$. navicula Zone silicoflagellates. Diatoms assigned to the $D$. hyalina and $R$. bulbosa Zones include first occurrences of Denticulopsis hyalina (15.0 Ma) in Section 38338-11-3 and Denticulopsis lauta (ca. 16.0 Ma) in Section 38338-11-4. The lowest occurrence of the benthic foraminifer Martinottiella communis (Section 338-11-3) is recorded in this sequence. Goll and Bjørklund (this volume) report the presence of radiolarians referable to the Ceratocyrtis broeggeri Zone (ca. 14.9-15.5 Ma) and C. eldholmi Zone (ca. 15.5-15.7 Ma). Locker and Martini (this volume) correlate this sequence with their lower Corbisema triacantha Zone (silicoflagellates; 14.518.6 Ma). An age of approximately $15.5-16.0 \mathrm{Ma}$ is assigned to this sequence, which is bounded at its top and base by 0.7 and 1.0 m.y. hiatuses, respectively.

The third sequence (mid rock Unit 2B) consists of $2 \mathrm{~m}$ (117.0$119.0 \mathrm{mbsf}$ ) of diatom ooze (Sections 38-338-12-2 to $-338-12, \mathrm{CC}$ ). Fossil assemblages include zone Ic dinocysts and $N$. navicula Zone silicoflagellates. The diatom assemblage assigned to the $R$. bulbosa Zone includes Thalassiosira fraga, which has its last occurrence at 16.1-16.3 Ma. Goll and Bjørklund (this volume) report the presence of radiolarians referable to the Pseudodictyophimus amundseni Zone (ca. 16.9-17.5 Ma). An age of 17.0 $\mathrm{Ma}$ is assigned to this very short sequence.

The fourth sequence (mid rock Unit 2B) consists of $40.4 \mathrm{~m}$ (124.5-164.9 mbsf) of diatom ooze (Sections 38-338-13-1 to $-338-17-3)$. Fossil assemblages include: zone IIb dinocysts, $N$. navicula Zone silicoflagellates, and $T$. fraga Zone to $R$. norwegica Zone diatoms. Goll and Bjørklund (this volume) assign Sections 38-338-13-1 to -338-13, CC to the Gondwanaria japonica kiaeri Zone (radiolarians; ca. 18.5-21.0 Ma) and Sections 38-338-14-1 to -338-17-3 to the Eucyrtidium saccoi Zone (ca. 21.0-21.6 Ma). Locker and Martini (this volume) correlate Sections 38-338-12-2 to -338-17-4 to the Naviculopsis navicula Zone (silicoflagellates; 18.6-20.9 Ma). The age range 19.0-20.5 Ma is assigned to this sequence, which is bounded above and below by $2.0-$ and $1.0-\mathrm{m} . \mathrm{y}$. hiatuses, respectively.

The fifth sequence (lower rock Unit 2B) consists of $15.1 \mathrm{~m}$ (167.1-182.2 mbsf) of diatom ooze (Sections 38-338-17-4 to -338-19-2). Fossil assemblages include: zone IIb dinocysts, $N$. navicula Zone to $N$. lata Zone silicoflagellates and Synedra jouseana Zone to $C$. praenitidus Zone diatoms. Goll and Bjørklund (this volume) report the presence of radiolarians referable to 
the Actinomma henningsmoeni Zone (ca. 21.6-22.1 Ma). This sequence is assigned to the age range $21.5-22.5 \mathrm{Ma}$.

The sixth sequence (rock Unit 2C) consists of $64.7 \mathrm{~m}$ (185.1 $249.8 \mathrm{mbsf}$ ) of interbedded calcareous diatom ooze and muddy diatom ooze (Sections 38-338-19-5 to -338-26-2). Sections 38$338-19$, CC to $-338-25$, CC contains a moderately-preserved assemblage of Oligocene benthic and planktonic foraminifers, including $A$. gracilis and $T$. alsatica, and zone III dinocysts. Berggren and Schnitker (1981) suggest that these bathyal benthic foraminifer faunas have affinities with the NW European Rupelian. The presence of $S$. distentus Zone calcareous nannofossils in these sediments is consistent with the above determination, if the sequence is restricted to lower zone NP24, as indicated by Martini and Müller (1985). The sequence also includes: $N$. lata Zone to $N$. biapiculata Zone silicoflagellates, $T$. irregularis Zone to Interval Zone diatoms, and $C$. robustus Zone to Phorticium $\mathrm{sp}$. A Zone radiolarians. On the basis of calcareous nannofossil biostratigraphy, the age range $28.0-30.5 \mathrm{Ma}$ is assigned to this sequence, which is bounded at its top and base by 6.0 - and 9.0 m.y. hiatuses, respectively.

The seventh sequence (rock Unit 2D) consists of $35.2 \mathrm{~m}$ (249.8-285.0 mbsf) of diatom ooze with muddy intercalations (Sections 38-338-26-2 to 338-29, CC). These sediments are barren of calcareous nannofossils, and the benthic foraminifer fauna is largely restricted to small but persistently occurring specimens of $S$. spectabilis. Although biostratigraphic control is poor, the age of this sequence is important because it serves as a reference standard for other local biozonations. The dinocyst flora is of limited assistance in bracketing the possible age range of the sequence. The presence of Phthanoperidinium amoenum and Wetzeliella symmetrica, which are not recorded in Site 643, may indicate that this sequence is older than the sequence in Cores 104-643A-47X to -643 A-57X. P. amoenum suggests an affinity to the basal sequence at Site 336 , although the range data for this species given by Williams and Bujak (1985) seems anomalously young (calcareous nannofossil Zones NP21-NP23). Other dinocysts in this sequence have older ranges. A. arcuatum has its oldest occurrence in Core 104-643A-51X, and this species is reported to range down to zone NP14 (Williams and Bujak, 1985). Consequently, these sediments at Site 338 probably accumulated during the time represented by calcareous nannofossil Zones NP14-NP16. The dinocyst floras of this sequence in Hole 338, which is the reference section for zones IV and V of Manum (1976), are regarded as coeval with Cores 104-643A-51X to $643 \mathrm{~A}-54 \mathrm{X}$ ( $A$. arcuatum to $A$. vittatum Zones). These data are consistent with the $C$. oblongus $/ T$. barbadense Zones boundary age of $42 \mathrm{Ma}$ (Fenner, 1984, 1985). Therefore, an age range of $41.0-43.5 \mathrm{Ma}$ is assigned to this sequence, which also includes: the silicoflagellate Distephanus quadria Zone and $C$. bimucronata Zone, and the radiolarian $L$. norvegiensis Zone and $C$. talwanii Zone.

The oldest sequence (rock Units 3A-3D) consists of $116.8 \mathrm{~m}$ (285.0-401.8 mbsf) of muds and sandy muds that are glauconitic at the top and grade downward into calcareous and zeolitic mud (Sections 38-338-30-1 to -338-42-2). Siliceous microfossils are absent in this sequence. Sections $38-338-32-1$ to $-338-33$, CC contain a sparse and restricted calcareous nannofossil flora, including the cold-water neritic species, Imperiaster obscurus. A secondary marker species was used to identify zone NP12 as low as Section $38-338-42-1$. Sections $38-338-32-0$ to $-338-37$, CC contain a relatively diverse benthic foraminifer fauna, including Turillina brevispira, which has its last occurrence in the North Sea at approximately the NP13/NP 14 boundary (King, 1983). Berggren and Schnitker (1981) have interpreted this fauna as bathyal and point out that the dominant planktonic foraminifers in this interval (Globigerina linaperta $=$ Subbotina patagonica) suggest a correlation with Zone P7, which helps to sub- stantiate the basal age for the sequence. The dinocyst flora is poor below Core 38-338-33, but this entire sequence was used as the reference section for zones VI-VIIB. There is no biostratigraphic control for Cores 38-338-30 to -338-31, but the sequence is assigned to the age range $54-56 \mathrm{Ma}$, primarily on the basis of the calcareous nannofossil flora.

\section{Site 342}

A $151.5-\mathrm{m}$ sedimentary section was discontinuously cored to basement at Site 342 on the outer Vøring Plateau (water depth, $1303 \mathrm{~m}$ ). This succession was described as four rock subunits, including $85.8 \mathrm{~m}$ of glacio-marine muds with dropstones and calcareous nannofossil ooze beds containing a Gephyrocapsa oceanica Zone flora and reworked Cretaceous and Paleogene constituents (Sections 38-342-1-1 to -342-3-1). These Pleistocene sediments are separated by a $4.5 \mathrm{Ma}$ hiatus from the underlying Miocene strata that are represented as four thin sequences.

The youngest Miocene sequence (upper rock Unit 2A) consists of $5.1 \mathrm{~m}$ of interstratified muds, siliceous muds, and minor calcareous nannofossil oozes (Sections 38-342-3-1 to -342-3-4). Benthic foraminifers include $M$. communis among a largely corroded calcareous assemblage, and the sequence is characterized by $R$. bulbosa Zone diatoms and $C$. triacantha Zone silicoflagellates. On the basis of its correlation to the upper Tessarastrum thiedei Zone (radiolarians), the sequence is assigned an age of $5.5 \mathrm{Ma}$ and is bounded at its base by a $9.5-\mathrm{m}$.y. hiatus.

Only the top of the next sequence (lower rock Unit 2A) was sampled (Section 38-342-3-4), but it may be as much as $32.4 \mathrm{~m}$ thick (including the uncored interval between Cores 38-342-3 and -342-4). Sediment character and fossil assemblages are similar to the previous sequence, but a Ceratocyrtis kladaros Zone radiolarian fauna has been identified (Goll and Bjørklund, this volume), and this sequence is assigned an age of $15.0 \mathrm{Ma}$.

The next sequence (rock Unit $2 \mathrm{H}$ ) consists of $19.0-47.5 \mathrm{~m}$ of diatom ooze (Sections 38-342-4-1 to $-342-5$, CC). Fossil assemblages remain unchanged from the overlying sequences, except that Cycladophora davisiania cornutoides Zone to Ceratocyrtis manumi Zone radiolarian faunas are present (Goll and Bjørklund, this volume). The zone Ic dinocyst flora in Sections 38-342-4-2 to $-342-5-5$ is consistent with this determination. Consequently the age range $16-17 \mathrm{Ma}$ is assigned to this sequence, which is bounded at its base by a $4.5-\mathrm{m}$.y. hiatus.

The oldest sequence (rock Unit $2 \mathrm{C}$ ) consists of $6 \mathrm{~m}$ of diatomaceous mud, which grades downward into sandy and glauconitic muds overlying basalt (Sections 38-342-6-1 to -342-6, CC). A lower Eucyrtidium saccoi Zone radiolarian fauna is present in this sequence (Goll and Bjørklund, this volume), which is in reasonable agreement with the Thalassiosira fraga Zone diatoms in Core 38-342-6 and zone IIa dinocysts in Section 38-3426-2. The $N$. lata Zone silicoflagellates of Sections 38-342-6-4 to $342-6, \mathrm{CC}$, are regarded as too old, but the $N$. navicula Zone flora in Sections 38-342-6-2 to -342-6-4 is consistent with the age assignment of $21.5 \mathrm{Ma}$.

Isotopic age dates for Site 342 basalts range from $41.3 \pm 1.0$ to $79.9 \pm 2.4 \mathrm{Ma}$ (Kharin et al., 1976). The site is shown as positioned on basement landward of magnetic anomaly $24 \mathrm{R}$ according to Eldholm, Thiede, Taylor et al. (1987a), and the oldest sediments at Site 342 are shown in Figure 11 as coeval with those of Site 338 ( $56 \mathrm{Ma}$ ). These oldest sediments at Site 342 are inferred to be bounded at their base by a $35-\mathrm{m}$.y. hiatus.

\section{Site 343}

A 283.0 -m sedimentary section was discontinuously cored to basement at Site 343 (water depth, $3130.0 \mathrm{~m}$ ) on the eastern margin of the Lofoten Basin at the foot of the Voring Plateau. This succession was described in five rock subunits, which include $107.5-145.5 \mathrm{~m}$ of glacio-marine muds and sandy muds 
with dropstones intercalated with sands, volcanic glass, and siliceous and calcareous oozes (rock Unit 1; Sections 38-343-1-1 to $-343-4$, CC).

The underlying sediments (rock Units 2-4) are presumed to be conformable and are presented in Figure 11 as a single Eocene sequence bounded at the top by $52-\mathrm{m}$.y. hiatus. These sediments are composed of 137.5-175.5 m of muds and interbedded muddy diatom ooze, volcanic ash, and recrystallized nannofossil ooze (rock Unit 2) overlying thinly-stratified hemipelagic muds, glauconitic muds, and turbidites (rock Units 3-4) (Sections 38-343-5-1 to -343-16-3). Although M. communis occurs in two samples from Section 38-343-5-2, the dinocyst flora was questionably correlated with zone V. The only age-diagnostic foraminifer in rock Unit 2 is $S$. spectabilis, and this monospecific fauna was also observed in the middle Eocene sequence of Site 338. Rock Units 3-4 contain sparse benthic foraminifer assemblages comparable with northwest German zones Eocene 13 (calcareous nannofossil Zones NP8-NP12 according to King, 1983, and Aubry, 1985). Rock Unit 2 is essentially barren of calcareous nannofossils, but the well-preserved siliceous microfossil assemblages comprising up to $70 \%$ of the sediments include an unzoned lower Eocene diatom flora, Archnocalpis? tumulosa Zone radiolarians and Naviculopsis minor Zone silicoflagellates. Martini (1977) correlated the $N$. minor Zone as upper zone NP12 to lower zone NP14. On the basis of the occurrence of Dictyocha frenguilli (silicoflagellates), Kaminski (1988) suggests that this sequence may be as young as calcareous nannofossil Zones NP16-NP17. For the present purposes, however, this zone is regarded as correlative with zone NP13, which is in agreement with Locker and Martini (1987), and the top of the sequence is assigned an age of $53 \mathrm{Ma}$. Rare and etched calcareous nannofossil floras in rock Units 3 and 4 include Imperiaster obscurus, whose range is restricted approximately to NP11-NP12. Siliceous microfossils are absent in these sediments, but the poor dinocyst assemblages are comparable to zone VIIa. An age of 55.5.Ma is assigned to the oldest sediments above basement.

\section{Site 345}

A 762-m sedimentary section was discontinuously cored to basement at Site 345 (water depth, $3195 \mathrm{~m}$ ) in the western Lofoten Basin between two segments of the Jan Mayen Fracture Zone. Grønlie et al. (1977, Figs. 1 and 11) show Hole 345 as sited on crust somewhat younger than magnetic anomaly ?21 (48.8-50.3 Ma according to Berggren et al., 1985). This interpretation is in reasonable agreement with the following discussion of the age of the oldest sediments penetrated in Hole 345, and it is here proposed that Site 345 rests on anomaly 17 (39.641.1 Ma). This age is in marked contrast to the $\mathrm{K} / \mathrm{Ar}$ determination of $27 \pm 3 \mathrm{Ma}$ for Hole 345 basalt reported by Kharin et al. (1976).

The succession was described as six rock subunits, including 46-55 m of glacio-marine muds and sandy muds with dropstones, volcanic ash and ooze intercalations containing Pseudoemiliania lacunosa Zone to Emiliania huxleyi Zone calcareous nannofossils (Unit 1, Sections 38-345-1-1 to $-345-5, C C$ ). Because of sparse fossil control, the underlying strata are divided into only three sequences, which are not completely consistent with the rock subdivisions. The oldest of these sequences may be a complex unit that cannot be differentiated biostratigraphically.

The upper sequence (rock Unit 2A) consists of $85.0-114.0 \mathrm{~m}$ (46.0-55.5 to $141.0-160.0 \mathrm{mbsf}$ ) of burrowed pelagic clay with minor mud, volcanic ash, and calcareous ooze intercalations (Sections 38-345-6-1 to -345-10, CC). Calcareous nannofossils are not reported for this sequence. Cores $38-345-6$ to $-347-7$ contain diatoms of the $R$. bulbosa Zone, which is reported to have a basal age of $19.5 \mathrm{Ma}$. The zone IIa dinocyst flora of Sections
38-345-6-2 to -345-9-3 includes Leptodinium sp. III (restricted to the E. paratabulata Zone at Site 643) and Batiacasphaera baculata (mid $A$. granosa Zone to mid I. patulum Zone at Site 643). The silicoflagellates in Cores 38-345-6 to -345-7 were questionably assigned to the $C$. triacantha Zone. This determination appears to be too young as compared to the age of the base of the $C$. triacantha Zone in Figure 11, but the age of the base of the lower $C$. triacantha Zone in Leg 104 sediments is indicated as 18.6 Ma in Figure 10 (backpocket). Based on the diatom and dinoflagellate data, we assign an approximate age of $18 \mathrm{Ma}$ for the top of the sequence, which is bounded by a $17-\mathrm{m}$.y. hiatus. $T$. fraga Zone diatoms and $N$. navicula Zone silicoflagellates occur in Core 38-345-8. The presence of $N$. lata Zone silicoflagellates and lowermost Miocene diatoms in Cores 38-345-9 to $-345-10$ provide biostratigraphic control for the base of this sequence, which is assigned an age of $23 \mathrm{Ma}$.

The middle sequence (rock Units 2B-mid 3A) consists of $389.5-399.0 \mathrm{~m}$ (141-160 to $530.5-559.0 \mathrm{mbsf})$ of alternating beds of intensively bioturbated muds and clays that become increasingly sand-rich and lithified with depth (Sections 38-345$11-1$ to $-345-32-2$ ). Turbidites and altered limestone beds are frequent in the lower part of this sequence. Siliceous microfossils and calcareous nannofossils are absent, but sparse and sporadic occurrences of Spirosigmoilinella-Karreriella siphonella Zone benthic foraminifers were reported. As in the lower Oligocene sequence at Site 336, dinocyst species associations in Cores 38345-11 to -345-21 suggest that these sediments accumulated during the late Eocene to early Oligocene hiatus at Site 643. The presence in Cores 38-345-15 to -345-21 of the dinocysts G. guiseppei and $D$. phosphoritica (restricted to the $A$. vittatum Zone to A. arcuatum Zone of Hole 643A) attests to sediment redistribution processes active at Site 345 . The dinocyst assemblage in Hole 345 also includes Impletosphaeridium sp., which has its oldest abundant and consistent occurrence in the Systematophora sp. 1 Zone of Hole 643A. The presence of Chiropteridium dispersum in Cores $38-345-11$ to $-345-13$ suggests a correlation to the lower portion of zone III at Site 338 , but poor dinocyst preservation and a 10-m.y. hiatus at the base of the upper Oligocene sequence at Site 338 result in limited reliability for the palynological biostratigraphy of this interval. Both C. dispersum and $H$. rigaudiae are present in the upper sediments of the Oligocene sequence at Site 336. Although $H$. rigaudiae was not recorded, we conclude that the oldest sediments of the middle sequence in Hole 345 could be as old as $34 \mathrm{Ma}$. Williams and Bujak (1985) indicated calcareous nannofossil Zone NP23 as the base of the range of Impletosphaeridium sp., which accords well with this correlation to Hole 336 . On the basis of this nondefinitive evidence, we assign an age range of 30-34 Ma for this sequence, which is bounded above by a $7-\mathrm{m}$.y. hiatus.

The lower sequence (rock Units mid 3A-3B) consists of 203.0-231.5 m (530.5-559.0 to $762 \mathrm{mbsf})$ of varied gravity flow and hemipelagic sediments, including a basal slump breccia overlain by turbidites interbedded with intensively bioturbated claystones and sandy mudstones (Sections 38-345-22-1 to -345$32-4)$. Biostratigraphic resolution is obliterated under these conditions, but it is hoped that general relationships are detectable. Siliceous microfossils and calcareous nannofossils are reported to be absent in this sequence. The benthic foraminifer biostratigraphy contrasts significantly with that of Eocene sediments in Hole $643 \mathrm{~A}$. The abrupt increase in abundance and frequency of occurrence of Haplophragmoides walteri in Section 38-345-25, CC may represent the base of the $H$. walteri Zone, but this species has sporadic rare occurrences down to the base of Core 38345-30. The lowest occurrence of Spirosigmoilinella sp. in Core 38-345-26 suggests a correlation with Core 104-643A-49X, but Spirosigmoilinella $\mathrm{sp}$. is sparsely and discontinuously represented throughout Hole 345 , and this species may not be a reliable 
marker at this locality. The consistent presence of common $\mathrm{Bu}$ dashevaella $\mathrm{cf}$. multicamerata to the base of Hole 345 and the total absence of $S$. spectabilis suggests that this sequence was deposited before Core 104-643-49X and after Core 38-338-36-2. Dinocysts are not common in this sequence. The oldest diverse occurrence is in Section 38-345-26-3, where the flora includes: Phthanoperidinium resistente $(=P$. eocenicum $)$, whose range in Hole $643 \mathrm{~A}$ is restricted to the Areosphaeridium arcuatum Zone, and Cyclonephelium ordinatum (= Glaphyrocysta ordinata), which occurs in Leg 104 sediment only in the basalt series (Core 104-642D-13X to -642D-14X). Because of the extensive hiatuses present in these oldest strata, we consider the foraminifers as more reliable age indicators and assign these basal sediments at Site 345 to the age range $38-41 \mathrm{Ma}$.

\section{DISCUSSION}

\section{Burial History and Hiatuses}

The series of eleven hiatuses in Figure 9 (backpocket) are named for the sequences they separate and can be recognized with variable confidence. Five of these hiatuses obviously interrupted sedimentation at both Sites 642 and 643 . Two others are inferred to be of regional scope, although they are diachronous. Two additional hiatuses appear only at one site, and there are two hiatuses of questionable validity. Despite the diachronic aspect of the many small and large unconformities at these two sites, the degree of Neogene erosional truncation or nondeposition is remarkably similar. Site 642 is $54.5 \%$ complete, and Site 643 is $58.3 \%$ complete to the base of the Neogene.

Throughout the upper portions of the successions, sediments of coeval age are consistently buried at greater depths at Site 642 than at Site 643, and the disparity in burial depth increases with increasing age (Fig. 9, backpocket). In the age range 0.8-1.9 $\mathrm{Ma}$, coeval sediments at Site 642 are buried approximately $12 \mathrm{~m}$ deeper than at Site 643 , and the difference increases to $52 \mathrm{~m}$ at an age of $6.0 \mathrm{Ma}$. The maximum depth disparity is $68 \mathrm{~m}$ at 14.4 $\mathrm{Ma}$. The crossover point occurs at 17.2-17.4 Ma, and older $\mathrm{Ne}-$ ogene sediments of coeval age are buried deeper at Site 643, although the chronostratigraphy of these sediments is particularly uncertain.

The largest and most controversial hiatus is $\mathrm{H} 1.0 / 2.0$, which represents intervals of 3.2-4.9-m.y. that are not represented by sediments at Sites 642 and 643, respectively. This hiatus correlates well with the TB2/TB3 offlap of Haq, Hardenbol and Vail (1987), and it marks a major change in the sedimentary records of the two sites, as is apparent in the burial history curve. Lower to middle Miocene sedimentation was less disrupted at Site 643 than at Site 642, whereas the converse is true for the younger sediments of these two sites. The Neogene sedimentary record at Site 643 prior to $13.7 \mathrm{Ma}$ is interpreted to be $82.6 \%$ complete, as compared to $45.5 \%$ at Site 642 for Neogene sediments older than 13.4 Ma. The opposite relationship holds for sediments above the middle Miocene unconformity. The sedimentary record is $81.4 \%$ complete for the past $10.2 \mathrm{Ma}$ at Site 642 and only $63.6 \%$ complete for the past $8.8 \mathrm{Ma}$ at Site 643 .

Some of the other hiatuses in the Leg 104 successions have ages comparable with the cycle and supercycle boundaries of Haq, Hardenbol and Vail (1985), but no such coincidence is discernible for other Leg 104 hiatuses. Hiatus H1.2/1.3 at Site 642 appears to coincide approximately with the TB2.2/2.3 boundary. Similarly, H1.2/1.4 at Site 643 and H1.3/1.5 at Site 642 may be associated with the TB2.3/2.4 boundary. Other possible associations include: H1.5/1.6 at Site 642 (TB2.4/2.5), H2.3/ 2.4 at both sites (TB3.6/3.7), and H2.2/2.3 at Site 643 (?TB3.4/ 3.5). Hiatuses having no apparent relationship to sequence stratigraphy include: $\mathrm{H} 1.1 / 1.2$ at both sites, $\mathrm{H} 1.4 / 1.5$ at Site 643 , and $\mathrm{H} 2.1 / 2.2$ at both sites.
Even more remarkable is the coincidence between Leg 104 hiatuses and the hiatus stratigraphy of Keller and Barron (1985) for the abyssal Pacific (Fig. 9, backpocket). Hiatus H1.1/1.2 is approximately coincident with $\mathrm{NH} 1 \mathrm{a}$, and the questionable hiatus in NSN1.2 at Site 642 approximately coincides with NH1b. Hiatuses H1.2/1.4 at Site 643 and H1.3/1.5 at Site 642 are within the age range of $\mathrm{NH} 2$, and hiatus $\mathrm{H} 1.0 / 2.0$ may be associated with $\mathrm{NH} 3$ and $\mathrm{NH} 4$. The latter relationship may be particularly significant if subthem NSN 1.6 at Site 642 is younger than is indicated on Figure 9, as suggested by Goll and Bjørklund (this volume). Furthermore, hiatus $\mathrm{H} 2.1 / 2.2$ at both sites is approximately coincident with NH6, and hiatus $\mathrm{H} 2.2 / 2.3$ at Site 643 may be associated with $\mathrm{NH} 7$. Hiatus NH8 is approximately $0.6 \mathrm{~m}$.y. older than hiatus $\mathrm{H} 2.3 / 2.4$.

In contrast to the potential problems associated with some of the Neogene sequences, the Paleogene sediments at all the sites appear to be organized in more obvious pan-oceanic sequences separated by pronounced hiatuses. Sediments in the age range 22-26 Ma are missing at Sites 346, 349, 350, 336, 354, and 338. Older erosion probably during $30-31$ Ma truncated the sedimentary succession at Sites 346, 349, 336, 337, and 643. An older erosional episode in the probable age range 40-42 Ma truncated the successions at Sites 336, 338, and ?643. A probable fourth episode truncated the successions at Sites 339, 338, $343, ? 643$ and ?642. These Paleogene sequences are not in accord with the global cycle chart of Haq, Hardenbol, and Vail (1987). There is evidence of middle Oligocene sedimentation at Sites $346,349,352,336$, and 338 during the major low stand of cycle TB1.1, and the two Oligocene hiatuses described above occurred during the previous and following high stands. A better fit with the sequence stratigraphy of Haq, Hardenbol, and Vail (1987) may exist for the Eocene, if the two major low stands of this epoch can be associated with the oldest hiatuses described above. The latest Oligocene hiatus ( $\mathrm{PHa}$ ) and two middle Oligocene hiatuses ( $\mathrm{PHaa}$ and $\mathrm{PHb}$ ) of these authors agree favorably with the three youngest Norwegian Sea hiatuses mentioned above. PHc and PHd are not apparent on Figure 11, but $\mathrm{PHe}$ is a good match with the fourth hiatus suggested for the Norwegian Sea.

Some of the reflectors of Skogseid and Eldholm (this volume) and Eldholm, Thiede, and Taylor (this volume) are recognizable in Figures 9-10, backpocket. Reflector LM is probably hiatus H1.1/1.2 at Sites 642 and 643. Reflector MM at Site 642 is reported at a depth approximately coincident with hiatus H1.2/1.3. In the Site Summaries section, it has been suggested that reflector MM may be equivalent to the hiatus $\mathrm{H1} .2 / 1.4$ at Site 643 , as an alternative to its location within Subsynthem NSN1.2. Reflector UP is regarded as hiatus $\mathrm{H} 2.3 / 2.4$, but alternatively it may be hiatus $\mathrm{H} 2.1 / 2.2$. Interestingly, the hiatus interpreted in this synthesis as having the longest duration at both Sites 642 and 643, H1.0/2.0, appears to have insufficient impedance contrast to produce a seismic reflector. Skogseid and Eldholm (this volume) recognize a sequence boundary within the succession between reflectors MM and UP that may be a seismic expression of $\mathrm{H} 1.0 / 2.0$. According to the interpretation of this synthesis, reflectors TO and A at Site 643 represent conformable lithologic boundaries (although the Paleogene biostratigraphy is not well constrained), but reflector A at Site 338 may represent the 6-m.y. hiatus in Core 38-338-19. Reflector $A^{\prime}$ at Site 643 may be the 10 -m.y. hiatus in Core 104-643A-46X. Reflector ME at Site 643 may be the 12-m.y. hiatus between Cores $104-643 \mathrm{~A}-49 \mathrm{X}$ and $-643 \mathrm{~A}-50 \mathrm{X}$, and this reflector is probably equivalent to reflector $\mathrm{A}^{\prime}$ at Site 338 .

The outer Vøring Plateau represents the down dip terminus of a depositional system including in its shoaler equivalents numerous structures of commercial interest. The biostratigraphy of thick Cenozoic successions penetrated by exploration drilling 
at Haltenbanken and Traenabanken have long been a source of controversy. It is hoped that our studies can be of use in resolving some of these problems, either by direct correlation of stratigraphic range data or by seismic sequence tracing.

Although all but the youngest sediments are truncated on the Nordland Ridge, the Cenozoic sections at the Halten Terrace and Traenabanken areas are interpreted by Dalland, Worsley, and Ofstad (1988) as undisrupted, with the exception of the middle Oligocene unconformity that separates the $584 \mathrm{~m}$ thick (combined thickness at the reference wells) Paleogene Rogaland and Hordaland Groups from the $1388 \mathrm{~m}$ thick Neogene Nordland Group. Two Oligocene unconformities may be present in these regions however, if the results of this synthesis can be correlated onto the Norwegian shelf, rather than the single truncation phase proposed by these authors. Hagevang and Rønnevik (1986, Fig. 10, backpocket) present a more detailed picture of the $\mathrm{Ce}-$ nozoic sedimentation history of Haltenbanken, and their interpretation has several interesting parallels to the present conclusions. The unconformity separating upper Pliocene and Quaternary sediments as shown by these authors would appear to be equivalent to $\mathrm{H} 2.3 / 2.4$ at Sites 642 and 643 . The Hordaland Group is represented as extending into the Miocene and in unconformable contact with the upper Pliocene Nordland Group, a relationship that might result from eastward merging of $\mathrm{H} \mathrm{1.0/}$ 2.0 and $\mathrm{H} 2.1 / 2.2$. The underlying package of conformable Oligocene/Miocene sediments is consistent with our interpretation of coeval sediments at Site 643 (Cores 104-643A-30X to -46X). Campbell and Ormaasen (1987) represent the Cenozoic succession of the central Hammerfest Basin (Barents Sea) as having been extensively truncated only during the late Miocene and middle Eocene, whereas the Central Graben region of the North Sea experienced a major disruption only during the early Miocene. The latter hiatus may be recognizable at Site 338. Thus, although all of the outer Vøring Plateau hiatuses have not been recognized at any single locality elsewhere on the Norwegian margin, coeval hiatuses have been reported in distant basins, and the sequence chronology here proposed may have regional application as biostratigraphic resolution improves.

\section{Biostratigraphy and Paleoenvironments}

Interesting inferences can be made from the paleoenvironmental curves (Fig. 9, backpocket) based on silicoflagellates (Ciesielski and Case; Locker and Martini, both this volume) and palynomorphs. Both Manum et al. (this volume) and Mudie (this volume) estimate fluctuations in the relative concentrations of dinoflagellates, pollen, and spores at Sites 642 and 643 , but the units of measure employed by these authors differ, and their results are not comparable as presented. Only the data of Manum et al. (this volume) are presented in Figure 9. Both dinoflagellates, pollen, and spores are more abundant in Synthem NSN 1.0 than in Synthem NSN 2.0. In Hole 643A, palynomorphs in general are most abundant in the lower Miocene Unit IV (Subsynthem NSN1.1), and they are significantly more abundant than in the coeval siliceous oozes of Hole 642D. This abundance contrast is enhanced by the $27 \%$ higher sedimentation rates of this sequence in Hole $643 \mathrm{~A}$ as compared to Hole $642 \mathrm{D}$. Moreover, there is a general trend of decreasing palynomorph abundance in the overlying siliceous oozes of Hole 643A, which suggests that dilution by other biogenic debris has a greater effect on palynomorph abundance than dilution by terrigenous clastics. These declining palynomorph abundances in Hole $643 \mathrm{~A}$ are coincident with a general trend of increasing relative frequencies of quadrate Distephanus, which is interpreted by Ciesielski and Case (this volume) as reflecting warming surfacewater temperatures with concomitant high productivity as indicated by abundance peaks of Bachmannocena and Caryocha during the time interval 14.0-16.6 Ma. In Holes 642C-642D, palynomorphs show a general trend of increasing abundance from 21.5 to $14.5 \mathrm{Ma}$, and the highest values are roughly contemporaneous with Bachmannocena and Caryocha abundance peaks. Both of the silicoflagellate paleotemperature curves indicate generally warm surface-water conditions throughout Synthem NSN1.0 at Site 642, although there are significant cold pulses and dissimilarities between the curves.

The silicoflagellate paleotemperature curves indicate a gradual westward expansion of the zone of temperate North Atlantic water crossing the Vøring Plateau during the time interval 15-19 $\mathrm{Ma}$, which culminated with surface-water temperatures at Site 643 approximately equivalent to those at Site 642 . This warming trend is also evident by comparing the dinoflagellate biostratigraphy of the two sites. Six taxa: Nematosphaeropsis dawnii, $N$. lemniscata, Impagidinium japonicum, Homotryblium vallum, Cribroperidinium giuseppei major, and Selenopemphix nephroides have first occurrences at Site 643 that are 1.3-5.0 m.y. younger than their first occurrences at Site 642 (Manum et al., this volume). This phenomenon can be explained as a possible warm adaptation for these species. However, no explanation can be offered for the observation that these species, as well as Polysphaeridium cf. subtile and Operculodinium crassum, persist as much as $9.6 \mathrm{~m}$.y. longer at Site 643. In contrast, Operculodinium placitum has a younger first occurrence and persists longer at Site 642 . There is no evidence of this warming trend of surface-water temperatures in the sparse and low-diversity benthic foraminifer assemblages of this interval (Osterman and Qvale, this volume). The silicoflagellate paleotemperature curves have maxima at 14.5-15.0 Ma for both sites, which coincide with sedimentary intervals in which Clathrospyris sandellae is absent or has very sporadic occurrences (Cores 104-643A-16H to $-643 \mathrm{~A}-18 \mathrm{X}$ and Cores $104-642 \mathrm{C}-21 \mathrm{H}$ to $-642 \mathrm{C}-22 \mathrm{H})$. This negative association suggests a moderate-to-cold adaptation for $C$. sandellae.

With the exceptions of very short Subsynthems NSN 1.3 and NSN 1.6, silicoflagellate paleotemperature curves for the sequences at Site 642 below Subsynthem NSN 2.4 have clearly developed upward trends of decreasing temperatures. The high temperatures interpreted for the base of each sequence declines gradually toward the top to temperatures roughly equivalent to those of Site 643 . The inferred cooling trends that preceded loss of sediment record in each of these sequences at Site 642 indicate an association between lowered sea level (and concomitant isolation of the Norwegian Sea) and increased erosion. Goll and Bjørklund (this volume) report evidence of enhanced rates of radiolarian evolution near the bases of sequences. These sets of observations suggest a model of sea-level falls resulting in lowered diversity in a partially isolated sea and increased bottom scour in the absence of an intermediate water exit vent. Rising sea levels would permit entrance of temperate waters with their associated biota (and possibly adaptive radiation of expatriate stocks) and re-establishment of more generally basin-wide sedimentation.

Palynomorphs are never abundant in Synthem NSN2.0 at both sites, possibly reflecting further dilution by calcareous biogenic debris. These moderate to low frequencies of palynomorphs at both sites are coincident with Bachmannocena peaks in sediments as young as 7.0 Ma at Site 643 and 5.5 Ma at Site 642. Both silicoflagellate paleotemperature curves for Site 642 indicate pronounced declines in surface-water temperatures at 9.2 $\mathrm{Ma}$, followed by a brief amelioration and further refrigeration at 8.2 Ma. The age of this latter inferred decline in temperature at the Vøring Plateau is remarkably close to the age of a cooling event for the East Greenland Current $(8.6 \mathrm{Ma})$, as proposed by Kaminski on the basis of his biostratigraphic studies of Site 646 in the Labrador Sea. The temperature index of Locker and Martini (this volume) appears to be more sensitive at the cold end of the spectrum and indicates a second brief warming at $5.4 \mathrm{Ma}$. It 
is important to note that the declining paleotemperature curves are roughly coincident with the depths at each site where Goll and Bjørklund (this volume) noted reduced preservation quality for siliceous microfossils, and preferential dissolution of critical taxa may have influenced these numerical frequency data.

\section{Biostratigraphic Indications of Tectonic History}

Manum (1976) presented curves of relative dinocyst frequencies of occurrence (cyst ratios) for six Leg 38 sites and concluded that deflections in these curves ("palyno-events") represented major shoreline displacements associated with three episodes of Norwegian Sea tectonism: the Eocene initial opening phase, the Oligocene opening of the Nansen Passage and spreading center jump, and the middle Miocene subsidence of the Iceland-Faeroe Ridge. Manum's data have been replotted against time in Figure 11, assuming that the ages of the sediments in these holes have been correctly interpreted. A similar curve presented by Manum et al. (this volume) displays high variance but generally high dinocyst frequencies throughout Hole 643A. Such a result is not unexpected, given the position of this site, which has probably occupied bathyal depths since cessation of the early rifting phase.

The dinocyst frequency curves in Figure 11 indicate that those portions of the Jan Mayen Ridge and Iceland Plateau represented by Sites 346 and 348 were sufficiently submerged to receive dominantly marine palynomorphs by $18-20 \mathrm{Ma}$, in anticipation of the shift in volcanicity centers from Jan Mayen to Iceland in the late Miocene. If emergent Jan Mayen was the principal source region for the siliciclastics that were deposited in the northern and western Norwegian Sea during much of the prelate Miocene Tertiary, as has been postulated by Talwani et al. (1976) and others, then submergence during the late Miocene should have excluded this ridge system as a major source region. Indeed, the ages of the increase in dinocyst relative frequencies in Site 346 and 348 sediments are remarkably similar to the age of the contact between mudstones and siliceous ooze (Units IV and III) in Hole 643A (19-20 Ma, Fig. 9, backpocket). This facies transition appears to have been associated with the submergence of both the Jan Mayen and Greenland-Scotland Ridge system, which shut off the supply of terrigenous debris and simultaneously permitted a broader inflow of North Atlantic water. Dinocyst frequency data suggest that Site 345 (located between two segments of the Jan Mayen Fracture Zone) similarly underwent depression some time during the interval 23-30 Ma (predating the event on the Jan Mayen Ridge). The sharp decline in dinocyst frequency just below the unconformity at 18 $\mathrm{Ma}$ indicates higher frequencies of terrestrial palynomorphs and possibly closer proximity to land vegetation. Site 336 on the Iceland-Faeroe Ridge was receiving principally marine palynomorphs since $37 \mathrm{Ma}$ and perhaps earlier, but these data are here regarded as less indicative of paleodepth because of the isolation of this locality from terrestrial source areas and its long exposure to pelagic currents. The sharply increasing dinocyst frequencies at 54-55 Ma for Vøring Plateau Sites 338 and 343 probably reflect the adjustment of these localities to pelagic conditions that continued unabated, with the exception of a brief but pronounced downturn at 29-30 Ma, when most of the Norwegian Sea experienced erosion and carbonates were deposited at Site 338. Dinocyst frequencies in Hole 338 decline again just below the loss of sediment record at $14 \mathrm{Ma}$, and the same relationship is observed in Hole 341 at 8-9 Ma.

\section{Biostratigraphy and Ash Bed Correlations}

Numerous Neogene tephra concentrations ranging from distinctive layers to enriched zones were detected during the course of routine shipboard description of Leg 104 cores (Eldholm, Thiede, Taylor, et al., 1987b, and Fig. 9, backpocket). Because of the distinctive properties of many of these deposits, 15 correlations between Sites 642 and 643 were proposed in Eldholm, Thiede, Taylor, et al. (1987b, p. 470) and the youngest three of these ash beds were additionally correlated variously to Site 644 (op. cit., p. 626). With the exception of the upper four of these correlations, which are not unreasonable, all of the remaining correlations are either improbable on biostratigraphic grounds (correlations 5-11, including two ash beds of inferred regional distribution) or at least suspect (correlations 12-15). The colorzoned and size-graded rhyolitic tephra in Section 104-643A$11 \mathrm{H}-1$ is improbably correlated with a similar tephra in Section $104-642 \mathrm{C}-15 \mathrm{H}-2$. The same judgement applies to the correlation of color-zoned icelandic tephra in Sections 104-643A-15H-4 and $-643 \mathrm{~A}-19 \mathrm{H}-3$. Interestingly, both magnetostratigraphy (Bleil, this volume) and biostratigraphy support the correlation of ashes in Sections 104-643A-7H-3 and -643A-10H-6, although Bitschene, Viereck, and Schmincke (this volume) conclude that these two ashes are unrelated on the basis of differing chemical composition. These authors prefer instead a correlation of ashes in Sections $104-643 \mathrm{~A}-7 \mathrm{H}-3$ and $-643 \mathrm{~A}-9 \mathrm{H}-3$, whereas all three units are here regarded as approximately temporally coeval.

Bitschene, Viereck, and Schmincke (this volume) conclude that the late Miocene ash beds can be correlated only as a group between Sites 642 and 643, and individual correlations of lowermiddle Miocene tephras are uncertain because of non-unique mineral assemblages and insufficient geochemical data. Taking an alternative view, Desprairies, Tremblay, and Laloy (this volume) propose a revised set of ash bed correlations between Sites 642 and 643 that are reasonably consistent with the biostratigraphic interpretations of this synthesis. The major exceptions are: the correlation of Section 104-643A-7H-3 with -642B-8H-1 and $-642 \mathrm{C}-7 \mathrm{H}-2$ crosses a hiatus, as does the correlation of Sections 104-643A-17X-1 with $-642 \mathrm{~B}-22 \mathrm{H}-4$. On biostratigraphic grounds, the ash beds in Cores 104-643A-26X to -643A-28X are approximately coeval with ash beds in Cores 104-642D-5X to $-642 \mathrm{D}-7 \mathrm{X}$, but individual correlations are probably not possible at this time.

The late Miocene interval of intensive low-K Icelandic volcanicity observed by both Bitschene, Viereck, and Schmincke and by Desprairies, Tremblay, and Laloy is here regarded to have occurred $8.0-8.5 \mathrm{Ma}$. This episode is represented by 12 ash beds in Cores $104-643 \mathrm{~A}-10 \mathrm{H}$ to $-643 \mathrm{~A}-11 \mathrm{H}$ and by nine ash beds in Cores $104-642 \mathrm{~B}-15 \mathrm{H}$ to $-642 \mathrm{~B}-16 \mathrm{H}$. Interestingly, it is immediately preceded by, or is coincident with, five diatom range termination events (Ciesielski and Case, this volume), and this association is approximately coeval with the TB $3.1 / 3.2$ offlap of Haq et al. (1987) and the NH5 hiatus of Keller and Barron (1985).

\section{CONCLUSIONS}

Perhaps the most obvious conclusion to be drawn from this synthesis is the biostratigraphic complexity of the Norwegian Sea during Cenozoic time. Many factors contribute to the nascent biostratigraphic status of this region. Restricted high-latitude diversity and endemism evident in all microfossil groups are clearly hindrances to detailed biostratigraphy in all arctic and antarctic regions. Another obstacle is the presence of numerous extensive hiatuses that preclude accumulation of continuous sedimentary records of long duration at any single locality. Moreover, marked facies contrasts with dissimilar microfossil assemblages occur across the Norwegian Sea basin in sediments of inferred coeval age. For example, siliceous ooze essentially barren of calcareous and agglutinated microfossils and palynomorphs was accumulating on the Vøring Plateau (Sites 339-340) during the middle Eocene, while siliciclastics with converse microfossil assemblages were deposited on the Iceland-Faeroe Ridge (Site 336) and Lofoten Basin (Site 345 ). Such problems can be partially overcome, however, if composite reference sections bearing broad microfossil as- 
sociations are available. Such sections do not occur in outcrop on the land areas surrounding the Norwegian Sea, and they have not been successfully drilled in the deep ocean for much of the Cenozoic. The principal exception is Site 644 , which serves this function remarkably well for the Pleistocene and late Pliocene. Regrettably, establishment of such sections has never received the attention it deserves during the past two scientific drilling legs in this region. DSDP Leg 38 occupied 17 localities chosen almost exclusively to meet structural and geophysical objectives, and the single stratigraphic locality (Site 341) was aborted after penetrating a condensed upper-middle Miocene section below thick Pleistocene overburden. Partly for this reason, Leg 38 sediments have never been placed in a precise biostratigraphic context.

Conventional piston coring in this region of thick Pleistocene overburden has provided little comparative material for investigations of the pre-glacial Cenozoic. Consequently, it has been necessary to correlate Leg 104 sedimentary successions using biostratigraphic range data derived from more temperate localities in the North Atlantic and even more distant regions. For much of the Cenozoic, however, the Norwegian Sea probably has been more isolated from the temperate Atlantic than it is today, and the reliability of these correlations with distant localities may be suspect. Cenozoic floras and faunas encountered in Leg 104 sediments generally have lower diversity than more temperate coeval assemblages and are characterized by more slowly evolving taxa with cosmopolitan or broad distributions and by sudden brief occurrences of temperate species without local evolutionary progenitors. A significant proportion of these marine assemblages appears to have arctic affinities, but little useful information can be derived from these taxa because the Cenozoic biostratigraphy of the Arctic Ocean is as yet poorly known.

Hole $643 \mathrm{~A}$ is positioned on a thick sedimentary accumulation near the base of the Vøring Plateau, but the middle Miocene succession is possibly disturbed by slumping, which severely restricts its value as a reference locality. Nevertheless, post-middle Miocene sedimentation on the outer Vøring Plateau is reasonably well understood, largely as a result of Leg 104, and a chronostratigraphic framework is developing, although much remains for future work. The Paleogene biostratigraphy of the Norwegian Sea is still very poorly-understood, however, with contradictory age interpretations based on sparse range data from divergent fossil groups. Resolution of these many problems is a project yet to be addressed by future scientific drilling.

High-latitude biostratigraphy may be further complicated by Cenozoic heterochrony documented for arctic terrestrial biota (Hickey et al., 1983) and antarctic shelf invertebrates (Zinsmeister and Feldmann (1984). Many polar taxa have been found to predate the oldest recorded occurrences of their temperate equivalents by as much as $40 \mathrm{~m}$.y. Potentially, diachronous events may introduce error into microfossil correlations in the Norwegian Sea, although the temporal offsets might be expected to be less severe for plankton and rapidly-transported benthos. The old last occurrences of Leg 104 Bolboforma taxa reported by Qvale and Spiegler (this volume) have been noted. Young ages for planktonic foraminifer biostratigraphic events have also been discussed. Undoubtedly there are other examples of diachronous events whose impact on Cenozic biostratigraphy is as yet unknown. The following two cases of probable diachronous events in Norwegian Sea correlations are taken from the preceding analysis of Leg 38 biostratigraphy.

If the chronostratigraphy of sedimentary sequences in Figure 11 is correct, then the last occurrence of Spiroplectammina spectabilis varies dramatically in age across the Norwegian Sea. This species ranges into the early Oligocene and persisted through much of the Isthmolithus recurvus Assemblage Zone at Sites 349 and 350 on the Jan Mayen Ridge and western margin of the Norway Basin. At Site 345, however, S. spectabilis was not ob- served in sediments ranging back to about 40 Ma by Verdenius and Van Hinte (1983), which is consistent with its occurrence in the middle Eocene sequence at Site 338 on the summit of the Vøring Plateau. At the foot of the Plateau (Site 643), however, S. spectabilis has only a limited occurrence in the RhabdamminaCyclammina Assemblage (53.0-54.5 Ma). Interestingly, the first occurrences of Spirosigmoilinella sp. and Karreriella siphonella appear to be essentially simultaneous at Sites 345 and 643. The last occurrences of $S$. spectabilis at Sites 349 and 350 would be more consistent with the last occurrence of this species in the Labrador Sea (end of the Eocene according to Kaminski, 1988), if Isthmolithus recurvus (calcareous nannofossil) had an older first occurrence in the Norwegian Sea. The convention adopted here of accepting calcareous nannofossil correlations as the primary age indicators forces most of the lower sequences of Holes 349 and 350 into the Oligocene, if sedimentation rates of $30 \mathrm{~m} /$ m.y. are employed. An older first occurrence for I. recurvus would allow accommodation of these sequences in the Eocene. Similarly, the thick sequence in Hole 336 is shown in Figure 9 (backpocket) as lower Oligocene on the basis of the occurrence of the I. recurvus Assemblage, which is not consistent with the presence of upper Eocene calcareous foraminifers (Berggren and Schnitker, 1981) and dinocysts regarded as reliable Eocene markers, ie.: Gonyaulacysta cf. guiseppei (= Criboperidinium guiseppei) and Phthanoperidinium amoenium (Manum, 1976). An older first occurrence for $I$. recurvus (Zone NP17-NP18) would allow the top of this sequence to be lowered about $3 \mathrm{~m}$.y. to the top of the Eocene, and consequently dinocyst zone IV of Manum (1976) would be more realistically constrained to the Eocene.

Another serious disagreement in Paleogene age interpretations involves the middle Eocene sequences of Sites 338 and 340. Diatom correlations to low-latitude standard biozonations by Fenner (1985) have been used to establish an approximate age of $42 \mathrm{Ma}$ for the base of the Craspedodiscus oblongus Zone, which serves as the foundation for ages assigned to these sequences and their associated biozonations. This supposition is not supported by silicoflagellate biostratigraphy, however. Locker and Martini (1987) propose a probable correlation of the lower Corbisema bimucronata Zone to upper calcareous nannofossil Zone NP15 (ca. 45.5-48 Ma). If this alternative is accepted, these sequences and associated biozonations at Sites 338 and 340 will require ages 2-4.5 m.y. older than those of Figure 11 .

If all of the Leg 104 recoveries from the three sites are integrated into a single chronostratigraphic composite, the resulting sedimentary record is only $51.7 \%$ complete for the past $57 \mathrm{Ma}$, assuming that Figure 11 is correct. Whereas the 252.8-m-thick section in Hole 644A appears to represent an approximately complete record of the past $2.9 \mathrm{Ma}$, only highly discontinuous records of the past 55 m.y. were recovered at Sites 642 and 643 . The pyroclastic bed (Unit IV) and underlying basalt series of Site 642 are regarded as older than 54 m.y., and they are separated by a $32.3-\mathrm{m}$.y. hiatus from the 277.6-m-thick Neogene succession that is condensed by numerous unconformities. The previous existence, but subsequent complete erosion, of other Paleogene sediments overlying the pyroclastic unit is indicated by strontium isotope datings of $37-38 \mathrm{Ma}$ by Smalley, Qvale, and Qvale (this volume), although no identifiable fossils of recognized late Eocene age have been found in the upper portion of Unit IV. The Paleogene record at Site 643 is somewhat more complete than at Site 642 , but two major hiatuses in the mudstones of Unit IV represent a total of 22.5 m.y. of unrecorded sedimentation. The Paleogene sediment record of Site 643 differs from that of Site 642 primarily in the presence of a $32.7-\mathrm{m}-$ thick sequence of disputed Eocene or Oligocene age and $75 \mathrm{~m}$ of lower Eocene/middle Eocene mudstones above the pyroclasticrich sediments overlying basalt breccia. Additionally, the sedi- 
mentary record of the latest Oligocene and earliest Miocene is more complete at Site 643 than at Site 642, but the converse is true for the post-middle Miocene. Sequestered at the margins of both the Vøring Plateau and the Jan Mayen Fracture Zone, Site 643 may have been more sheltered from the effects of bottom scour and slumping that appear to have truncated the sediment cover on more elevated portions of the plateau during the early Miocene. By the late Miocene, however, plateau sedimentation may have prograded westward sufficiently to expose Site 643 to these processes, while Site 642 occupied a less vulnerable location.

Viewed as a whole, this record of Cenozoic sedimentation on the Vøring Plateau is more impressive for what is missing rather than for the thin sequences that remain, and the following discussion will treat Legs 38 and 104 as two sets of sites separated geographically by the Vøring Plateau Escarpment (the outer and inner Vøring Plateaus). Outer Vøring Plateau sediments were penetrated at Sites $338,342,343,642$, and 643 . The Neogene sedimentary record of Sites 642 and 643 has been described in this synthesis as a series of ten unconformity-bounded sequences (subsynthems). The Neogene sedimentary succession at Site 338 has been divided into eight thin sequences, the youngest of which is $14-15 \mathrm{Ma}$. The upper five of these sequences are similar to coeval sediments at Site 642 and represent Subsynthems NSN 1.5, NSN 1.3 and NSN 1.2 (the lower two sequences fit imperfectly into Subsynthem NSN 1.1). The sequences recognized at Site 338 are separated by hiatuses having a total duration of 28.3 m.y. The upper Oligocene and middle Eocene sequences have no correlatives at the other outer plateau sites, suggesting extreme instability of Paleogene sediments prone to gravity sliding at this elevated locality exposed to vigorous bottom currents. The recoveries from Sites 342 and 343 attest even more thoroughly to similar conditions at greater depths. The 151.5-m-thick sedimentary succession at Site 342 has been divided into four sequences 5.1-?47.5 m thick, the lowest of which is less than $20 \mathrm{Ma}$. These sequences may represent in-situ deposition of Subsynthems NSN 2.2, NSN1.4, NSN 1.2, and NSN 1.1 , or alternatively they may represent slump remnants derived from higher regions of the plateau. Assuming that basement basalts at Site 342 are approximately coeval with those of Site 338, the oldest Site 342 sediments are bounded basally by a 35 m.y. hiatus. At Site 343 , a $52 \mathrm{~m} . \mathrm{y}$. hiatus separates the Pleistocene glacio-marine sediments from the underlying $137.5-175.5 \mathrm{~m}$ of biosiliceous and sandy mudstones.

The sedimentary history of the inner Vøring Plateau is known only from four localities (Sites 339, 340, 341, and 644). Sites 341 and 644 penetrated thick glacio-marine sections $323 \mathrm{~m}$ and $226 \mathrm{~m}$ thick, respectively. Hiatus $2.3 / 2.4$ is apparently missing at Site 644 , or it may be of only short duration below Hole 644A. Sedimentation at Site 341 partially fills Hiatus 1.0/2.0, although sediments younger than $7.0 \mathrm{Ma}$ were not recovered at this site. Neogene truncation at both Sites 338 and 341 may indicate reactivated tectonism of the northern escarpment. Sites 339 and 340 provide only a restricted view of Eocene sedimentation disturbed by diapir emplacement. This limited data set suggests greater continuity of sedimentation on the inner Vøring Plateau prior to the eventual truncation that affected all four sites. The Vøring Plateau Escarpment obviously influenced sedimentation patterns across the region, with less disruption of depositional processes in the basin behind the escarpment. On the outer Vøring Plateau, however, sedimentation exceeded erosion only locally after the escarpment, which served as a sediment dam, was breached in the late Oligocene to early Miocene.

Marked contrasts in Paleogene sedimentary facies across the Vøring Plateau are evident from Figure 11. Possibly the oldest sedimentary rocks recovered from the Vøring Plateau are the basal mudstones at Sites 338 and 343, which presumably are cor- relative with the intercalations of the lower Eocene basalt series of Site 642. Accumulation of major quantities of biogenic silica began at approximately $54 \mathrm{Ma}$ at Site 643 , probably simultaneous with and possibly induced by pyroclastic deposition at Sites 642 and 643. Traces of opal-CT lepispheres have been observed throughout the mudstones of Unit IV at Site 643 (Henrich, this volume), indicating the probable prior occurrence of siliceous microfossils. This biogenic debris must have been only a minor sedimentary component throughout the Paleogene and lowermost Miocene at this locality at the foot of the plateau, where deep currents transported gravity flow deposits probably from western or northern source regions. On higher elevations of the plateau, siliceous microfossil ooze accumulation began sometime between 49-54 Ma, suggesting clastic-starved deposition under cold and highly fertile surface waters. The concentration of terrigenous components appears to decrease toward the Norwegian coast. The upper middle Eocene oozes of Site 338 contain up to $30 \%$ clay, whereas clays are present only in trace quantities in approximately coeval oozes at Site 340 . The middle Eocene was an interval of nearly global siliceous ooze deposition, and it is not necessary to propose a local mechanism or source to explain this facies.

The duration of this first cycle of siliceous ooze deposition on the Vøring Plateau is not precisely known, but significant amounts of biosiliceous debris were received on the Aegir Ridge as late as $31 \mathrm{Ma}$, and possibly more purely biosiliceous deposition persisted on the Vøring Plateau until approximately that time. A pronounced facies change is evident in sediments having an approximte age of $30.5 \mathrm{Ma}$ at Site 338. Depression of the lysocline below the plateau crest and reduction of surface-water fertility led to deposition of carbonate oozes containing only traces of siliceous microfossils. The low frequency of dinocysts relative to the total palynomorph assemblages (Manum, 1976) is consistent with the widespread erosion that was prevalent during that time. Siliceous microfossils are again abundant and well preserved in sediments having an approximate age of $30 \mathrm{Ma}$ at Site 338, and carbonate deposition was largely suppressed by $28.5 \mathrm{Ma}$.

There is no record of sedimentation anywhere on the crest of the Vøring Plateau during the interval 22-28 Ma, but muddy siliceous ooze was accumulating at Sites 338 and 642 by $22 \mathrm{Ma}$ and continued rather uniformly under relatively warm surfacewater conditions with only brief interruptions until the major middle Miocene unconformity. Because these sediments represent the oldest clay-rich deposits on the crest of the plateau since the lower Eocene mudstones at Sites 338, a clay suspension load derived from east or southern sources is implied.

Mudstone deposition abruptly terminated 19-20 Ma at Site 643 and was soon followed by accumulation of siliceous oozes containing low concentrations of clay and other terrestrial clastics, which suggests cessation of turbidity flow transport from the west and western expansion of the zone of fertile surface waters. Down slope transport of sediments from more elevated regions of the plateau may have contributed to the high accumulation rates experienced at Site 643 during the interval $14-19 \mathrm{Ma}$ ( $40.3 \mathrm{~m} / \mathrm{m} . \mathrm{y}$. post-compaction), but the lower clay concentrations at Site 643 compared to Sites 338 and 642 suggest that these mud-rich shallow sediments were not a primary source.

The timing of the onset of relatively persistent Neogene carbonate deposition on the Vøring Plateau is somewhat controversial. For the purposes of this synthesis, we have placed this event at $13.6 \mathrm{Ma}$, just below the major middle Miocene unconformity. This decision is justified on the basis of the need to provide a local source for the middle Miocene microfossils inferred to have been reworked into the basal sediments immediately overlying the unconformity in Hole 642B (not in Hole 642C). Alternatively, the lysocline may have been depressed at some time 
during the hiatus. Carbonate concentrations fluctuate broadly in the Neogene sediments at Site 642 and are most abundant and persistent during the interval 3-4 Ma (top of subsynthem NSN 2.3). Carbonates are generally less well developed at Site 643. Despite the presence of carbonates in the Neogene succession, sedimentation rates overall are much less at both sites $(16.8 \mathrm{~m} / \mathrm{m}$.y. post-compaction). Surface-water temperatures declined sharply during the interval 8.0-9.5 Ma according to silicoflagellate interpretations by both Ciesielski and Case (this volume) and Locker and Martini (this volume), but the degree to which their data have been influenced by the deteriorating siliceous microfossil preservation at approximately the same hole depths is unknown. This sharply declining biosiliceous preservation quality is attributed to increasing concentrations of illite in the younger succession by Goll and Bjørklund (this volume).

Sediments recovered at the eight DSDP sites from other localities of the Norwegian Sea indicate that siliciclastic sedimentation was dominant in these western and northern regions and persisted longer than on the Vøring Plateau. The only truly pelagic sediments recovered at these sites are the upper Eocene muds at Site 337 and the middle Oligocene calcareous ooze and chalk at Site 352. The sedimentary facies and microfossil assemblages at Site 345 are similar to those of Site 643 , although the sequences are not isochronous. The presence of minor quantities of siliceous microfossils in the upper sequence is not regarded as a significant facies contrast, because silica phase varies as a function of burial depth, and similar concentrations of siliceous microfossils may have occurred originally at greater depths in Hole 345 and also at Site 643 before transformation to opal-CT. In Figure 11, the upper sequence at Site 345 is shown

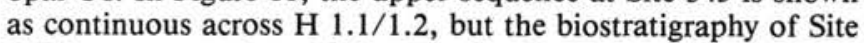
345 is not presently sufficiently refined to resolve such details. The absence of sediments younger than $18 \mathrm{Ma}$ may simply reflect the severe Neogene erosion that has affected all the Norwegian Sea sites, with the exception of Sites 336, 348, 642, 643, and 644. Truncation is most pronounced at Site 345 , however, possibly due to displacements of the Jan Mayen Fracture Zone.

Inevitably, much remains unfinished. Greater efforts to extract and identify calcareous microfossils from the indurated chalks recovered at both Legs 38 and 104 sites may provide important new dates that will help resolve some of the controversies discussed in the paper, as will a comprehensive study of diatom biostratigraphy. Microfossils already extracted from the shale intercalations of Hole 642E await thorough analyses, and new occurrences must be sought. This synthesis has been based largely on published biostratigraphic data, and new multidisciplinary research is needed to more firmly integrate the biostratigraphies of these two legs. Correlations between the Norwegian Sea and northern North Atlantic drill sites are also urgently needed, as well as closer cooperation between biostratigraphy and seismic stratigraphy. Finally, time-dependent research requires an accurate clock. The chronometer of geology (still mainly biostratigraphy) requires additional calibration in the Norwegian Sea. More detailed knowledge of the geologic history of this region cannot be achieved until a concerted effort is made to obtain the appropriate reference sections upon which this science is dependent.

\section{ACKNOWLEDGMENTS}

Thanks are extended to all authors of papers included in this volume for access to their manuscripts before publication, and to many members of the Leg 104 "paleo crew" who have tirelessly offered corrections and suggestions. Much credit is due Dorothee Spiegler and Sigurd Locker, who have made important contributions to the interpretation of these biostratigraphic data. M. C. Boulter contributed text explaining the biostratigraphic and paleoenvironmental significance of the pollen and spore data. Svein Manum and M. A. Kaminski have been very forthcoming with a wealth of information on dinoflagellates and benthic for- aminifers, respectively. Jan Backman, J. A. Barron, W. A. Berggren, L. H. Burckle, Olav Eldholm, Julianna Fenner, H. J. Schrader, Jörn Thiede and J. G. Verdenius reviewed the manuscript and offered proposals for its improvement, some of which were followed. Finally, my employer, The Continental Shelf Institute, deserves my special gratitude for financial support and scientific encouragement during this long task.

\section{REFERENCES}

Aksu, A. E., and Kaminski M. A., in press. Neogene planktonic foraminifer biostratigraphy of Baffin Bay and the Labrador Sea. In Srivastava, S. P., Arthur, M., Clement, B., et al., Proc. ODP, Sci. Results, 105: College Station, TX (Ocean Drilling Program).

Aubry, M.-P., 1985. Northwestern European Paleogene magnetostratigraphy, biostratigraphy and paleogeography: calcareous microfossil evidence. Geology, 13: 198-202.

Baldauf, J. G., 1987. Diatom biostratigraphy of the middle- and highlatitude North Atlantic Ocean, Deep Sea Drilling Project Leg 94. In Ruddiman, W. F., Kidd, R. B., et al., Init. Repts. DSDP, 94: Washington (U.S. Govt. Printing Office), 729-762.

Barron, J. A., 1985a. Miocene to Holocene planktic diatoms. In Bolli, H. M., Saunders, J. B., and Perch-Nielsen, K. (Eds.), Plankton Stratigraphy: Cambridge (Cambridge Univ. Press), 736-809.

Barron, J. A., 1985b. Late Eocene to Holocene diatom biostratigraphy of the equatorial Pacific Ocean, Deep Sea Drilling Project Leg 85. In Mayer, L., Theyer, F., et al., Init. Repts. DSDP, 85: Washington (U. S. Govt. Prining Office), 413-456.

Berggren, W. A., Kent, D. V., Flynn, J. J., and Van Couvering, J. A., 1985. Cenozoic geochronology. Geol. Soc. Am. Bull., 96:1407-1418.

Berggren, W. A., and Schnitker, D., 1981. Cenozoic marine environments in the North Atlantic and Norwegian-Greenland Sea. In Bott, M. H., Saxov, S., Talwani, M., and Thiede, J. (Eds.), Structure and development of the Greenland-Scotland Ridge: new methods and concepts. Nato Conference, Ser. IV., Mar. Sci., 8:495-548.

Bjørklund, K. R., 1976. Radiolaria from the Norwegian Sea, Leg 38 of the Deep Sea Drilling Project. In Talwani, M., Udintsev, G., et al., Init. Repts. DSDP, 38: Washington (U.S. Govt. Printing Office), 1101-1168.

Blow, W. H., 1969. Late middle Eocene to Recent planktonic foraminiferal biostratigraphy. In Brönniman, R., and Renz, H. H. (Eds.), Proc. Init. Conf. Planktonic Microfossils, 1st, Geneva, 1967, Vol. 1: Leiden (E. J. Brill), 199-421.

Campbell, C. J., and Ormaasen, E., 1987. The discovery of oil and gas in Norway: an historical synopsis. In Spencer, A. M., et al. (Eds.), Geology of the Norwegian Oil and Gas Fields. London (Graham and Trotman), 1-37.

Chang, K. H., 1975. Unconformity-bounded stratigraphic units. Geol. Soc. Am. Bull., 86:1544-1552.

Dalland, A., Worsley, D., and Ofstad, K. (Eds.), 1988. A lithostratigraphic scheme for the Mesozoic and Cenozoic succession offshore mid- and northern Norway. Norwegian Petroleum Directorate Bull., 14.

Dzinoridze, R. N., Jouse, Koroleva-Golikova, G. S., Kozlova, G. E., Nagaeva, G. S., Petruschevskaya, M. G., and Strelnikova, N. I., 1978. Diatom and Radiolarian Cenozoic Stratigraphy, Norwegian Basin, DSDP leg 38. In Talwani, M., Udintsev, G., et al., Init. Repts. DSDP, 38 (Supplement Vol., Washington (U.S. Govt. Printing Office), 289-427.

Eldholm O., Thiede, J., Taylor, E., et al., 1987a. Summary and preliminary conclusions, ODP Leg 104. In Eldholm, O., Thiede, J., Taylor, E., et al., Proc. ODP, Init. Repts., 104: College Station, TX (Ocean Drilling Program), 751-771.

Eldholm O., Thiede, J., Taylor, E., et al., 1987b. Proc. ODP, Init. Repts., 104: College Station, TX (Ocean Drilling Program).

Fenner, J., 1984. Eocene-Oligocene planktic diatom stratigraphy in the low latitudes and high latitudes. Micropaleontology, 30:319-342.

Fenner, J., 1985. Late Cretaceous to Oligocene planktic diatoms. In Bolli, H. M., Saunders, J. B., and Perch-Nielsen, K., Eds., Plankton Stratigraphy: Cambridge (Cambridge Univ. Press), 713-762.

Goll, R. M., and Bjørklund, K. R., 1980. The evolution of Eucoronis fridtjofnanseni, n.sp. and its application to the Neogene biostratigraphy of the Norwegian-Greenland Sea. Micropaleontology, 26: 356-371.

Grønlie, G., Chapoman, M., and Talwani, M., 1979. Jan Mayen Ridge and Iceland Plateau: origin and evolution. In Grønlie, G., et al., 
Geophysical studies in the Norwegian-Greenland Sea. Norwegian Polar Institute, Rept., 170:25-47.

Hagevang, T., and Rønnevik, H., 1986. Basin development and hydrocarbon occurrence offshore mid-Norway. In Halbouty, M. T. (Ed.), Future petroleum provinces of the world. AAPG Mem., 40:599613.

Haq, B., Hardenbol, J., and Vail, P. R., 1987. Chronology of fluctuating sea level since the Triassic. Science, 235:1156-1167.

Hickey, L. J., West, R. N., Dawson, M. R., and Choi, D. K., 1983. Arctic terrestrial biota: paleomagnetic evidence of age disparity with mid-northern latitudes during the late Cretaceous and early Tertiary. Science 221: 1153-1156.

Kaminski, M. A., 1988. Cenozoic deep-water agglutinated foraminifera in the North Atlantic. [Ph.D. dissert.]. Joint Program in Oceanography and Oceanographic Engineering, Woods Hole Oceanographic Institution and Massachusetts Institute of Technology.

Keigwin, L. D., 1987. Pliocene stable-isotope record of Deep Sea Drilling Project Site 606: sequential events of ${ }^{18} \mathrm{O}$ enrichment beginning at 3.1 Ma. In Ruddiman, W. F., and Kidd, R. B., et al., Init. Repts. $D S D P$, 94: Washington (U.S. Govt. Printing Office), 911-920.

Keller, G., and Barron, J. A., 1985. Paleodepth distribution of Neogene deep-sea hiatuses. Paleoceanography, 2:697-713.

Keller, G., Herbert, T., Dorsey, R., D'Hondt, S., Johnsson, M., and Chi, W. R., 1987. Global distribution of late Paleogene hiatuses. Geology, 15: 199-203.

Kharin, G. N., Udintsev, G. B., Bogatikov, O. A., Dmetriev, J. I., Raschka, H., Kreuzer, H., Mohr, M., Harre, W., and Echardt, F. J., 1976. K/Ar age of the basalts of Norwegian-Greenland Sea DSDP Leg 38. In Talwani, M., Udintsev, G., et al., Init. Repts. DSDP, 38: Washington (U. S. Government Printing Office), 755-759.

King, C., 1983. Cenozoic micropalaeontological biostratigraphy of the North Sea. Rep. Inst. Geol. Sci. UK, No. 82/7.

Locker, S., and Martini, E., 1987. Silicoflagellaten aus einigen russischen Palaogen-Vorkommen. Senckenbergiana lethaea, 68:21-67.

Manum, S. B., 1976. Dinocysts in Tertiary Norwegian-Greenland Sea sediments (Deep Sea Drilling Project Leg 38), with observations on palynomorphs and palynodebris in relation to environment. In Talwani, M., Udintsev, G., et al., Init. Repts. DSDP, 38: Washington (U.S. Government Printing Office), 897-919.

Martini, E., 1971. Standard Tertiary and Quaternary calcareous nannoplankton zonation. In Farinacci, A. (Ed.), Proc. Plankt. Conf. 2nd, Rome, 1970, 2: 739-785.

Martini, E., 1977. Neue daten zum Paläozän und unter Eozän im südlichen Nordseabecken. Newsl. Stratigr., 6:97-105.

Martini, E., and Müller, C., 1976. Eocene to Pleistocene silicoflagellates from the Norwegian Greenland Sea (DSDP Leg 38). In Talwani, M., Udintsev, G. et al., Init. Repts. DSDP, 38: Washington (U.S. Government Printing Office), 857-895.

Martini, E., and Müller, C., 1986. Current Tertiary and Quaternary calcareous nannoplankton stratigraphy and correlations. Newsl. Stratigr., 16:99-112.

Miller, K. G., Gradstein, F. M., and Berggren, W. A., 1982. Late Cretaceous to early Tertiary agglutinated benthic foraminifera in the Labrador Sea. Micropaleontology, 28:1-30.
Müller, C., 1976. Tertiary and Quaternary calcareous nannoplankton in the Norwegian-Greenland Sea, DSDP Leg 38. In Talwani, M., Udintsev, G., et al., Init. Repts. DSDP, 38: Washington (U.S. Govt. Printing Office), 823-842.

Murphy, M. A., and Salvador, A., 1988. Unconformity-bounded stratigaphic units: discussion and reply. Geol. Soc. Am. Bull., 100:155156.

Owens, D. E., 1987. Commentary: usage of stratigraphic terminology in papers, illustrations, and talks. J. Sediment. Petrol., 57:363-372.

Piasecki, S., 1980. Dinoflagellate stratigraphy of the Miocene Hodde and Gram Formations, Denmark. Bull. Geol. Soc. Den. 29:53-76.

Salvador, A., 1987. Unconformity-bounded stratigraphic units. Geol. Soc. Am. Bull. 98:232-237.

Schrader, H.-J., Bjørklund, K. R., Manum, S., Martini, E., and Van Hinte, J., 1976. Cenozoic biostratigraphy, physical stratigraphy and paleooceanography in the Norwegian-Greenland Sea, DSDP Leg 38 paleontological synthesis. In Talwani, M., Udintsev, G., et al., Init. Repts. DSDP, 38: Washington (U.S. Govt. Printing Office), 11971242.

Schrader, H.-J., and Fenner, J., 1976. Norwegian Sea Cenozoic diatom biostratigraphy and taxonomy. Part II, diatoms at Leg 38, taxonomic references. In Talwani, M., Udintsev, G. et al., Init. Repts. DSDP, 38: Washington (U.S. Govt. Printing Office), 963-1099.

Skarbø, O., and Verdenius, J. G., (Eds.) 1986. Catalogue of microfossils, Quaternary-Tertiary. Publ. No. 113, Continental Shelf Institute.

Talwani, M., and Eldholm, O., 1977. Evolution of the NorwegianGreenland Sea. Geol. Soc. Am. Bull., 88:969-999.

Talwani, M., Udintsev, G., et al., 1976. Init. Repts. DSDP, 38: Washington (U.S. Government Printing Office).

Verdenius, J. G., and van Hinte, J. E., 1983. Central Norwegian-Greenland Sea. Tertiary arenaceous foraminifera, biostratigraphy and environment. In Proc., Workshop on Arenaceous Foraminifera, 1st, 7-9 September 1981. Publ. No. 108, Continental Shelf Institute, 173-223.

Weaver, P.P.E., and Clement, B. M., 1987. Magnetobiostratigraphy of planktonic foraminiferal datums: Deep Sea Drilling Project Leg 94, North Atlantic. In Ruddiman, W. F., Kidd, R. B., et al., Init. Repts. DSDP, 94: Washington (U.S. Govt. Printing Office), 815-830.

Williams, G. L., and Bujak, J. P., 1985. Mesozoic and Cenozoic dinoflagellates. In Bolli, H. M., Saunders, J. B., and Perch-Nielsen, K. (Eds.), Plankton Stratigraphy: Cambridge (Cambridge Univ. Press), 847-964.

Zinsmeister, W. J., and Feldman, R. M., 1984. Cenozoic high latitude heterochroneity of southern hemisphere marine faunas. Science 224: 281-283.

Date of initial receipt: 10 October 1988

Date of acceptance: 10 February 1989

Ms 104B-203 